\title{
Conceptual Design Study Advanced Concepts Test (ACT) Facility
}

F. R. Zaloudek

Dry Cooling Enhancement Program Staff

September 1978

Prepared for the U.S. Department of Energy under Contract EY-76-C-06-1830

Pacific Northwest Laboratory

Operated for the U.S. Department of Energy by 


\title{
NOTICE
}

This report was prepared as an account of work sponsored by the United States Government. Vetther the United States nor the Department of Energy, nor any of their employees, nor any of their contractors, subcontractors, or their einvioyees, makes any warranty, express or implied, or assumes any legal liability or responsibility for the accuracy, completeness or usetulness of any information, apparatus, product or process disclosed, or represents that its use would not infringe privately cwned rights.

The views, opinions and conclusions contained in this report are those of the contracter snd do not necessarily represent those of the United States Government or the United States Department of Energy.

\author{
PACIFIC NORTHWEST LABORATORY \\ operated by \\ BATTELLE \\ for the \\ UNITED STATES DEPARTMENT OF ENERG $i$ \\ Under Contract EY-76-C-06-1830
}

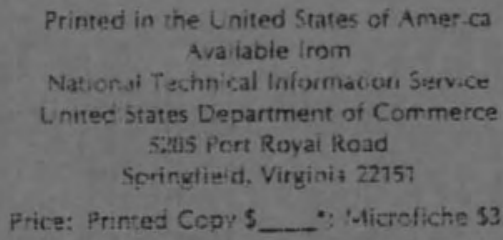

\begin{tabular}{|c|c|}
\hline *Pages & Seliing Price \\
\hline $001-025$ & $\$ 4,00$ \\
\hline $025 \cdot 050$ & 54.50 \\
\hline 051.075 & $\$ 5.25$ \\
\hline $076-100$ & $\$ 6.00$ \\
\hline $101-125$ & $\$ 6.50$ \\
\hline $125-150$ & 57.25 \\
\hline $151 \cdot 175$ & 53.00 \\
\hline 175.200 & $\$ 9,00$ \\
\hline 201.225 & $\$ 9.25$ \\
\hline $226-250$ & 59.50 \\
\hline 251.275 & $\$ 1075$ \\
\hline 275.500 & $5: 1.20$ \\
\hline
\end{tabular}
: Aliurfiche $\$ 3.00$ 
PNL-2715

UC- 12

\section{0}

CONCEPTUAL DESIGN STUDY

ADVANCED CONCEPTS TEST (ACT) FACILITY

F. R. Zaloudek

Dry Cooling Enhancement Program Staff

September 1978

Prepared for

the U.S. Department of Energy

under Contract EY-76-C-06-1830

Pacific Northwest Laboratory

Richland, Washington 99352 


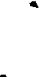


FOREWORD

The Advanced Concepts Test (ACT) project has been a major focus of the Dry Cooling Enhancement Program sponsored by the Department of Energy (formerly ERDA and the AEC) at Pacific Northwest Laboratory (PNL) for the past two years. During this time the Electric Power Research Institute (EPRI) has also been carrying on an active program with Union Carbide/Linde in developing a dry cooling system similar to that under study at PNL, based on the use of ammonia as a heat transfer fluid between the power plant and the heat rejection tower. Recognizing the similarity of needs for a large scale test of this concept, the program managers of the two agencies have been planning the ACT project so that it would reflect the needs of each. Initially DOE (ERDA) was to fund the major part of the design and construction while EPRI was to carry out most of the operations.

With the formation of the DOE as a new department in October 1977, the responsibility for carrying out such large scale tests as this was not clearly assigned. This situation, together with the reduction in the budget for nuclear R\&D, would have forced an uncertain hiatus on the project had not EPRI made the decision that the need for this technology within the utility industry was sufficiently pressing to justify a lead role by EPRI in the design and construction phase. EPRI anticipates that DOE will again take a major role during the operation of the facility.

This document was first assembled to specify the project management plan under DOE (primary) sponsorship. It has now been revised to reflect the new anticipated arrangement under EPRI sponsorship of the design and construction phases and to show the interaction among the principal parties, EPRI-UCC/Linde-PNL. Other government agencies, state agencies, and select utilities, will hopefully contribute to the accompanying technology development program and join with the DOE in the funding of the operations phase of the program. 
$\bullet$

․․

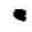




\section{CONTENTS}

FOREWORD.

INTRODUCTION.

GENERAL FACILITY DESCRIPTION.

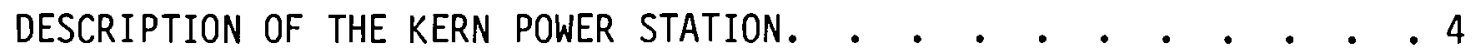

FACILITY/POWER PLANT RELATIONSHIP. • • • • • • • • • • • 6

WATER SOURCE AND QUALITY. • • • • • • • • • • • • • • • •

EQUIPMENT AND ARRANGEMENT OF DEMONSTRATION FACILITY. . • • • . 10

Condenser and Vacuum System. • • • • • • • • • • 11

Ammonia Heat Transport System. • • • • • • . . . 12

Cooling Tower. • • • • • • • • • • • • • . 12

Water Treatment Facility. • . . • . . • . . . 14

Ammonia Storage. • . . . . . . . . • . . . . . 14

Evacuation and Purge System. . . . . . . . . . . 14

Vent System. • • • • • • • • • • • • • • • . 15

Controls. . . • . • . . . . • . . • . . 15

Test Instrumentation. . . . . . . . . . . . 16

CODES AND STANDARDS. • • • • • • • • • • • • • • • • • • 17

Civil and Structural. • • • • • • . • . • . 17

Mechanical. • • • • • • • • • • • • . 17

Electrical. • • • • . • . • • • • • . . 18

Occupational Safety and Health. • . . . • . . . . . 18

ARCHITECTURAL AND STRUCTURAL DESCRIPTION. • • • • • • • • • • 19

REBOILER BUILDING. • • • • • • • • • • • • • • • • 19

COOLING TOWER. • • • • • • • • • • • • • • • • • • • 19

WATER TREATMENT FACILITY. • • • • • • • • • • • • • • 22

AMMONIA STORAGE FACILITY. • • • • • • • • • • • • • • • 22

ROADS AND WALKWAYS. • • . • • . • • • • • . • • . . 23

MECHANICAL DESCRIPTION. • • • • • • • • • • • • • • • • • • • 24

EXHAUST STEAM DIVERSION LINE. • • • • • • • • • • • 24

STEAM CONDENSER/BOILER. • • • • • • • • • • • • • • • • • • 24 


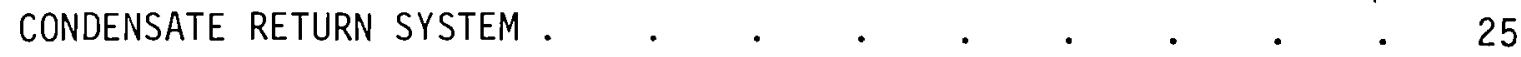

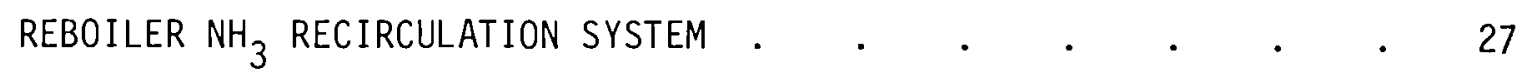

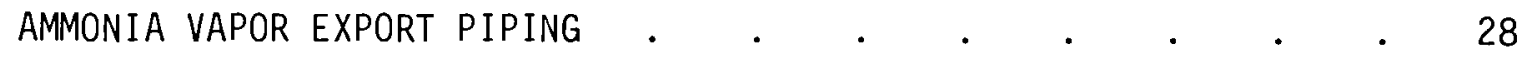

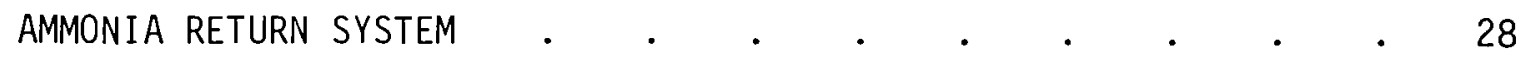

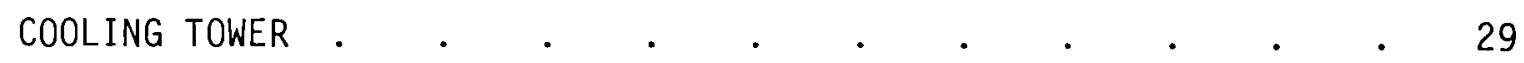

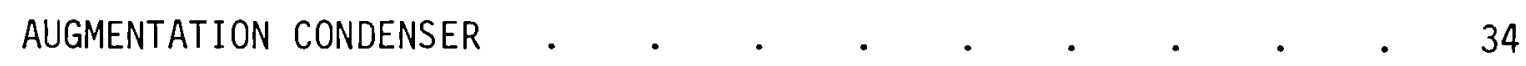

DELUGEATE SUPPLY SYSTEM .

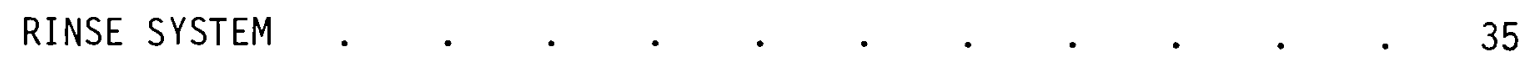

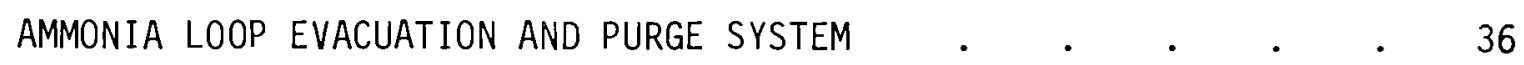

AMMONIA VENT SYSTEM . . . . . . . . . . . . . . . 37

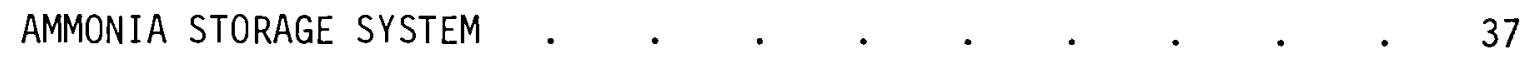

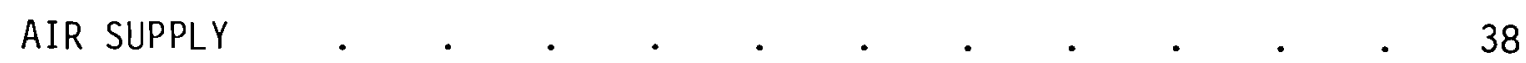

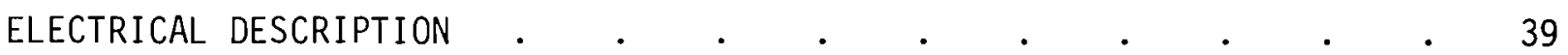

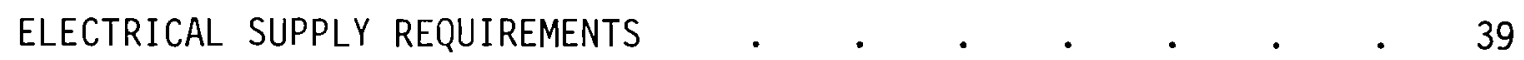

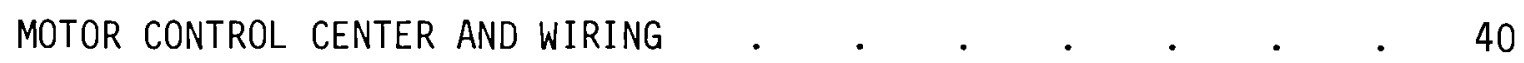

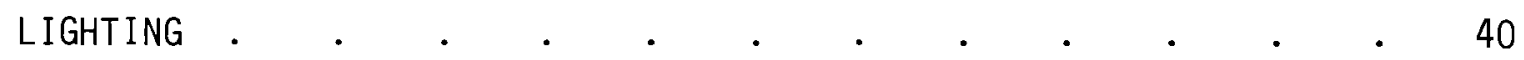

INSTRUMENTATION AND CONTROLS

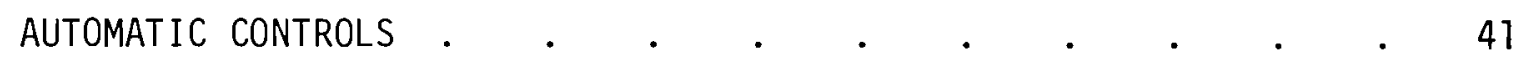

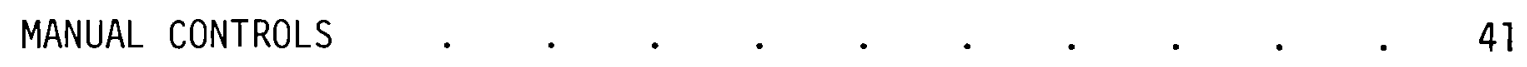

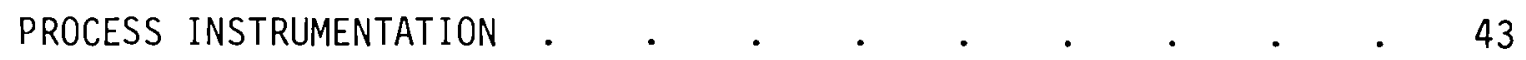

AMMONIA VAPOR DETECTION • . . . . . . . . . . . . . 43

ANNUNCIATORS AND ALARMS . . . . . . . . . . . . . . 45

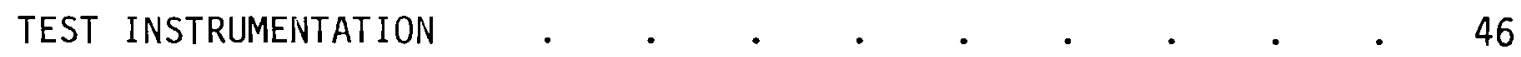

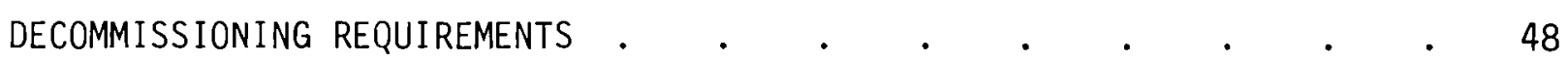

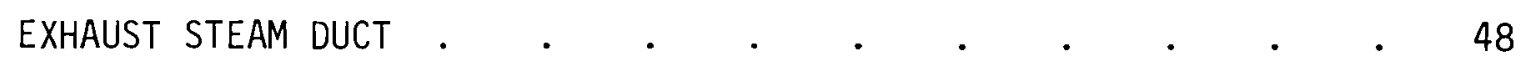

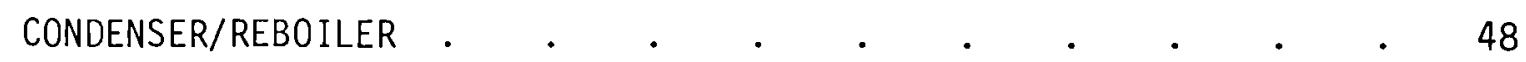

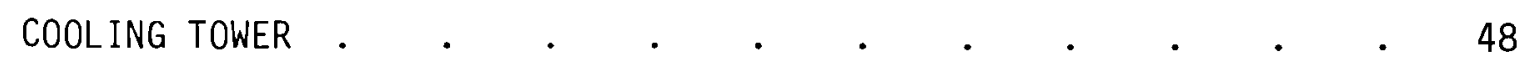

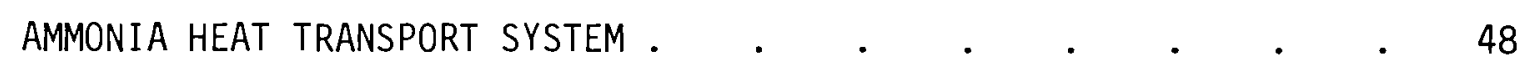

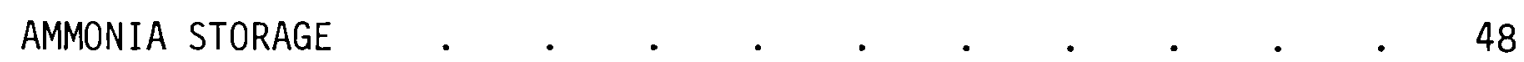

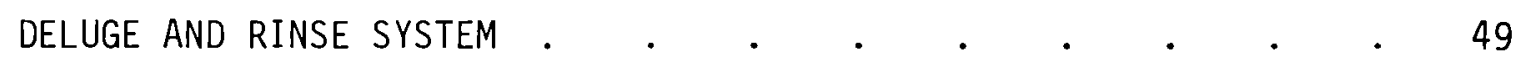

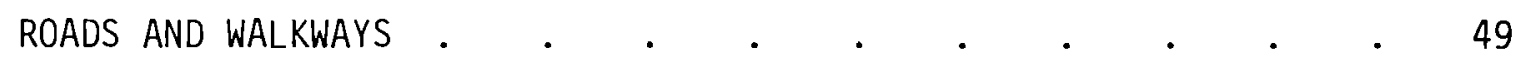

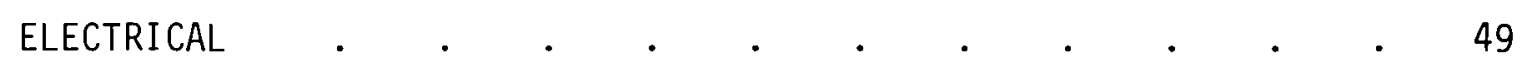

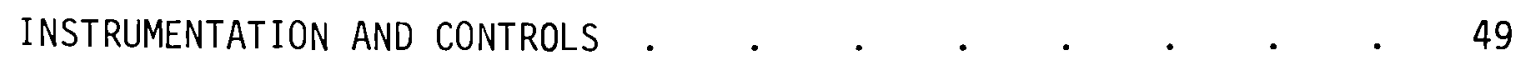


OCCUPATIONAL AND ENVIRONMENTAL SAFETY

ENVIRONMENTAL ASSESSMENT ..$\quad \cdot \quad \cdot \quad \cdot \quad \cdot \quad \cdot \quad \cdot \quad \cdot 50$

OCCUPATIONAL SAFETY. $. \quad . \quad . \quad . \quad . \quad . \quad . \quad . \quad . \quad . \quad 50$

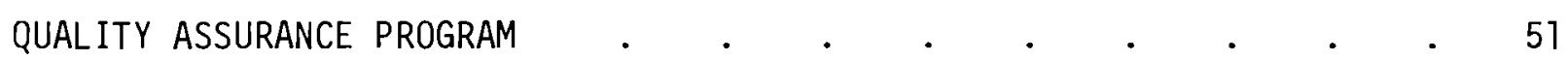

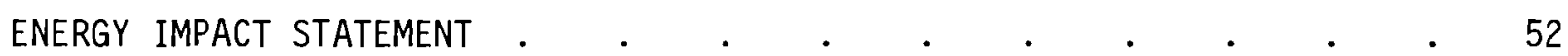

APPENDIX A - FIVE YEAR SUMMARY OF CLIMATOLOGICAL
DATA BAKERSFIELD, CALIFORNIA

APPENDIX B - DRY COOLING TOWER DEMONSTRATION FACILITY

APPENDIX $C$ - WATER ANALYSES KERN POWER STATION . . . . . . . . $\quad$ c-1

APPENDIX D - CONCEPTUAL DESIGN DRAWINGS . . . . . . . . . ${ }^{\circ}$ D-1

APPENDIX E - ENVIRONMENTAL IMPACT ASSESSMENT FOR

A FACILITY FOR THE STUDY AND DEMONSTRATION

OF A DRY/WET COOLING TOWER CONCEPT WITH

AMMONIA PHASE-CHANGE HEAT TRANSPORT SYSTEM . . . E-1

APPENDIX $F$ - APPLICATION OF INDUSTRY PRACTICES TO

DESIGN OF AN AMMONIA PHASE CHANGE HEAT

TRANSPORT PROCESS PILOT PLANT . . . . . . . F-1 


\section{FIGURES}

1 Site Plan for the Kern Power Plant . . . . . . . . 5

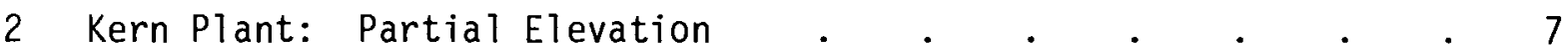

3 Kern Plant: Plan, Grade $412.00 \mathrm{ft}$. $\quad$. . . . . . . . . 8

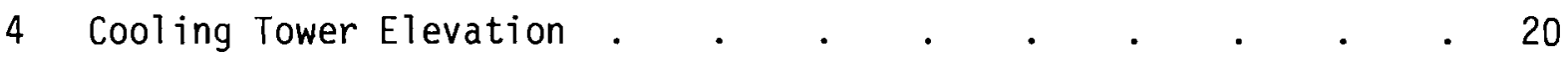

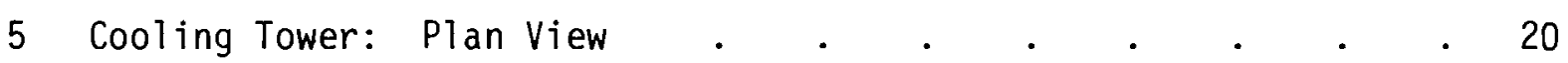

6 Cooling Tower: Typical Transverse Cross Section . . . . . . 21

7 Cooling Tower: Typical Longitudinal Cross Section . . . 21

8 Forgo Heat Exchanger Assembly .

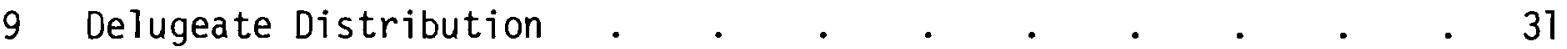

\section{TABLES}

1 Condenser/Reboiler Specification Sheet . . . . . . . . 26

2 Forgo Heat Exchanger Design Parameters . . . . . . . 32

3 Chip-Fin Tubing Description . . . . . . . . . . . 32

4 Curtiss-Wright Heat Exchanger Design Parameters . . . . . . 33

5 Three-Phase, $440 \mathrm{~V}$, Power Requirements . . . . . . . . 39

6 Automatic Controls . . . . . . . . . . . . . . 42

7 Manual Control Specifications . . . . . . . . . . . 43

8 Process Instrumentation . . . . . . . . . . . . . . . . 44

9 Annunciator and Alarm . . . . . . . . . . . . . . . 45

10 Test Instrumentation . . . . . . . . . . . . 47 


\section{CONCEPTUAL DESIGN STUDY}

ADVANCED CONCEPTS TEST (ACT) FACILITY

\section{INTRODUCTION}

Dry cooling of thermal power plants has been the subject of several research programs funded by the Electric Power Research Institute (EPRI) and the Energy Research and Development Administration/Department of Energy (DOE) for about four years. The objectives of these programs are to develop dry cooling systems and combination dry/wet cooling systems that can be applied to conserve scarce water resources and increase power plant siting flexibility. These systems are to be developed, in conjunction with utilities and the cooling tower industry, with a minimum increase in cost of generating electricity. The initial thrust of the DOE program was the demonstration of existing technology for air cooling as applied to power plant heat rejection. However, extensive contacts with utilities, architect-engineering firms, and cooling tower manufacturers identified high cost as the main deterrent to the use of dry cooling, rather than unfamiliarity with the technology. Consequently the present thrust of both the DOE and EPRI programs is toward the identification and demonstration of advanced technology that promises to markedly reduce the cost of dry cooling.

A number of advanced concepts for both a11-dry and wet-dry cooling systems have been studied for their technical feasibility and economic potential in both the EPRI and DOE programs. In the DOE program, the analyses have involved the development of a design optimization computer code for both all-dry and wet-dry systems that was then used to compare the cost of electricity generated in a plant equipped with the various advanced concepts for heat rejection. The comparison of various dry-wet systems was also done through a series of design studies in which conceptual design of a number of heat rejection systems for a specific plant site were made and cost estimated by an architect-engineering firm. Both approaches resulted in very favorable cost projections for a system concept employing ammonia as an intermediate heat transfer medium between the plant and the tower. To provide augmentation of the heat rejection capability 
through water evaporation, two approaches were investigated. In one, the ammonia air-cooled condenser was arranged to allow direct water evaporation from the radiator-like surface of the dry tower for added cooling on hot summer days. In the other, a conventional shell-and-tube ammonia condenser cooled by circulation water and close linked with an evaporative cooling tower was used. Each of these studies showed that the ammonia system should be less expensive to build and operate than several different conventional systems; about $35 \%$ less for the case of the optimized all-dry, and approximately $25 \%$ less for the dry-wet system. The principal factors contributing to the cost benefits obtained with the ammonia system are 1 isted below.

1. Because condensation of ammonia in the dry tower is isothermal, there is a larger temperature driving force for heat transfer than in an indirect system; thus less surface area is required.

2. Ammonia vapor has a much lower volumetric flow rate and specific volume than steam, resulting in smaller transfer lines between the plant and the tower than required for a direct condensing system.

3. Since freezing is not a problem in the cooling tower during dry operation, louvers, drain valves or other low temperature safety systems are not required.

4. No pumping is required to move vapor to the tower and very little pumping power is required to move liquid back to the plant.

The purpose of the Advanced Concepts Test (ACT) Facility is to evaluate and demonstrate the overall performance of these water-augmented, ammonia system concepts at a sufficiently large scale to apply the results and experience gained to commercial power systems. It is believed that the results of this effort will enhance the rate of development and utilization of this technology with attendant water conservation and siting flexibility benefits.

The ACT project was originally planned to be part of the DOE Dry Cooling Enhancement Program. This program also included general technology tasks directed toward the development of other advanced heat transfer surfaces applicable to large-scale testing, identification of water chemistry limits to prevent scaling and corrosion, and comparative evaluations of other advanced concepts of dry (dry/wet) cooling. Additional funding from EPRI and other 
sources was anticipated, particularly during the operating phase of the project. Several factors have changed these plans so that now EPRI has assumed the lead role in the design and construction of ACT. Additional funding from DOE and other agencies and organizations is still anticipated.

The facility will be built with the cooperation of the Pacific Gas and Electric Co. (PG\&E) at the Kern Plant in Bakersfield, California. It will be sized to accommodate a11 of the exhaust steam from one nominal 6,000-kW steam turbine. It will be well instrumented to define its operation for meteorological conditions at that site. See Appendix A for a meteorological profile of the site. The deluge/ammonia cooling system was designed to operate all dry at the ambient air temperature under $55^{\circ} \mathrm{F}$, and to operate with increasing water augmentation at temperatures above $55^{\circ} \mathrm{F}$. This will ensure that the augmentation system will be rigorously exercised during musch of the operating season.

When completed, the facility will be large enough to produce valid data on operating problems, reliability, and some indication of system costs. The results will be widely disseminated to utilities, architect-engineers and manufacturers of cooling system components with the objective of encouraging the near-term commercialization of these concepts. 


\section{GENERAL FACILITY DESCRIPTION}

The facility will be located at the site of PG\&E's Kern Power Station which is immediately west of Bakersfield, California. The site is served by highway and rail transportation; a spur runs onto the plant site from the AT\&SF rail line located to the south of the site. This spur line runs within several hundred feet of the proposed facility construction site. A site plan is shown in Figure 1.

\section{DESCRIPTION OF THE KERN POWER STATION}

The Kern Power Station was built in 1948 and contains two units rated nominally at 60,000 and $80,000 \mathrm{~kW}$. The two 1,800 rpm main turbines are of the single-casing, single-flow type and are designed for steam conditions of $1,350 \mathrm{psig}$ and $925^{\circ} \mathrm{F}$ and $3 \mathrm{in}$. $\mathrm{Hg}$ back pressure. They have four extraction openings for supplying steam to the closed feedwater heaters and to the evaporators. The generators are hydrogen-cooled and supply power at $13.8 \mathrm{kV}$, 3-phase, 60 cycles to the plant substation where it is increased to $70 \mathrm{kV}$ and $115 \mathrm{kV}$ for transmission.

Each unit is equipped with a "house turbine" to provide an independent power source for the station auxiliaries. The Unit 1 house turbine is rated at 6,000 kW and Unit 2 at 7,500 kW. These 3,600 rpm house units are the automatic extraction, condensing type with the steam extraction used to maintain a constant pressure of 5 psig in the deaerating heater (No. 4 Heater). Normally, these house units are operated at minimum load consistent with supplying the deaerating heater and providing cooling steam for the turbine. This minimum load varies from approximately 500 to $1,500 \mathrm{~kW}$.

The Unit 1 main condenser is of the single-pass, cross-flow type with divided water boxes and center steam space. It contains $35,000 \mathrm{ft}^{2}$ of $7 / 8$ in., No. 18 BNG wall, Admiralty metal tubes. The hot well is of the deaerating and storage type. The air ejector is a twin element, 2-stage ejector with surface inter- and after-condensers. Each element has a capacity of $13.5 \mathrm{cfm}$ of free air. 


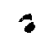

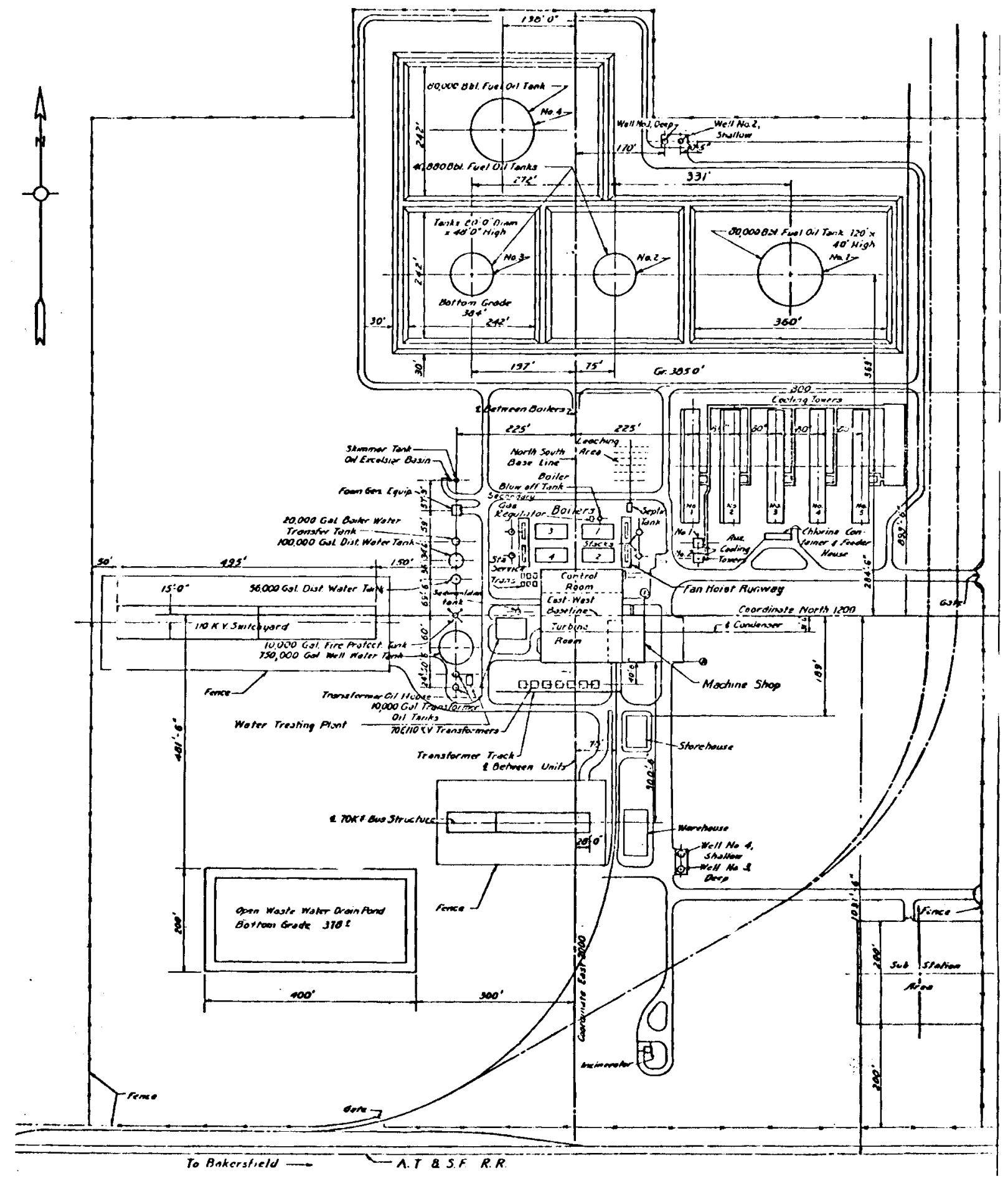

FIGURE 1. Site Plan for the Kern Power Plant 
The Unit 1 main condenser has two horizontal 8-in., three-stage condensate pumps driven by 100-hp motors. These pumps are designed for $1,200 \mathrm{gpm}$ and $185 \mathrm{ft}$ total dynamic head (TDH). Circulating water is supplied by two horizontal 30-in. circulating pumps with 600-hp motors. Each pump is designed for $32,500 \mathrm{gpm}$ and $55 \mathrm{ft} \mathrm{TDH.}$

The Unit 1 house condenser is of the single-pass, reverse-flow type with divided water boxes. They contain 4,000 $\mathrm{ft}^{2}$ of $7 / 8 \mathrm{in}$. Admiralty metal tubing, $7 / 8$ in. $O D$ and No. 18 BWG wall.

The house unit condensers have two horizontal 3-in., two-stage condensate pumps designed for $170 \mathrm{gpm}$ and $185 \mathrm{ft} \mathrm{TDH}$. Circulating water is supplied by one horizontal 18-in. single-stage, double-suction pump designed for 9,000 gpm and 51-1/2 ft TDH. The circulating water is cooled in forced draft cooling towers located immediately northeast of the plant.

There are four boilers, two associated with each unit. Each boiler will produce $450,000 \mathrm{lb} / \mathrm{hr}$ at $1,550 \mathrm{psi}$ and $935^{\circ} \mathrm{F}$. The boilers are presently oil-fired. There are two 80,000-bbl and two 40,880-bbl fuel oil storage tanks located immediately to the north of the plant.

Elevation and plan views of the equipment arrangement for the Kern Power Station are shown in Figures 2 and 3.

\section{FACILITY/POWER PLANT RELATIONSHIP}

The facility will be designed to condense $60,000 \mathrm{lb} / \mathrm{hr}$ of exhaust steam from the No. 1 house turbine $(6,000 \mathrm{~kW})$, transport the heat of condensation from the condenser to the cooling tower by an ammonia phasechange heat transport system, and dissipate this heat to the environs by a dry/wet deluge cooling tower. The plant is normally operated with the house turbine producing minimum output consistent with supplying the steam demand for the deaerating heater through the turbine extraction port. During demonstration testing, the extraction port may be closed, or remain partly open, depending on the facility's steam demand and the plant's 


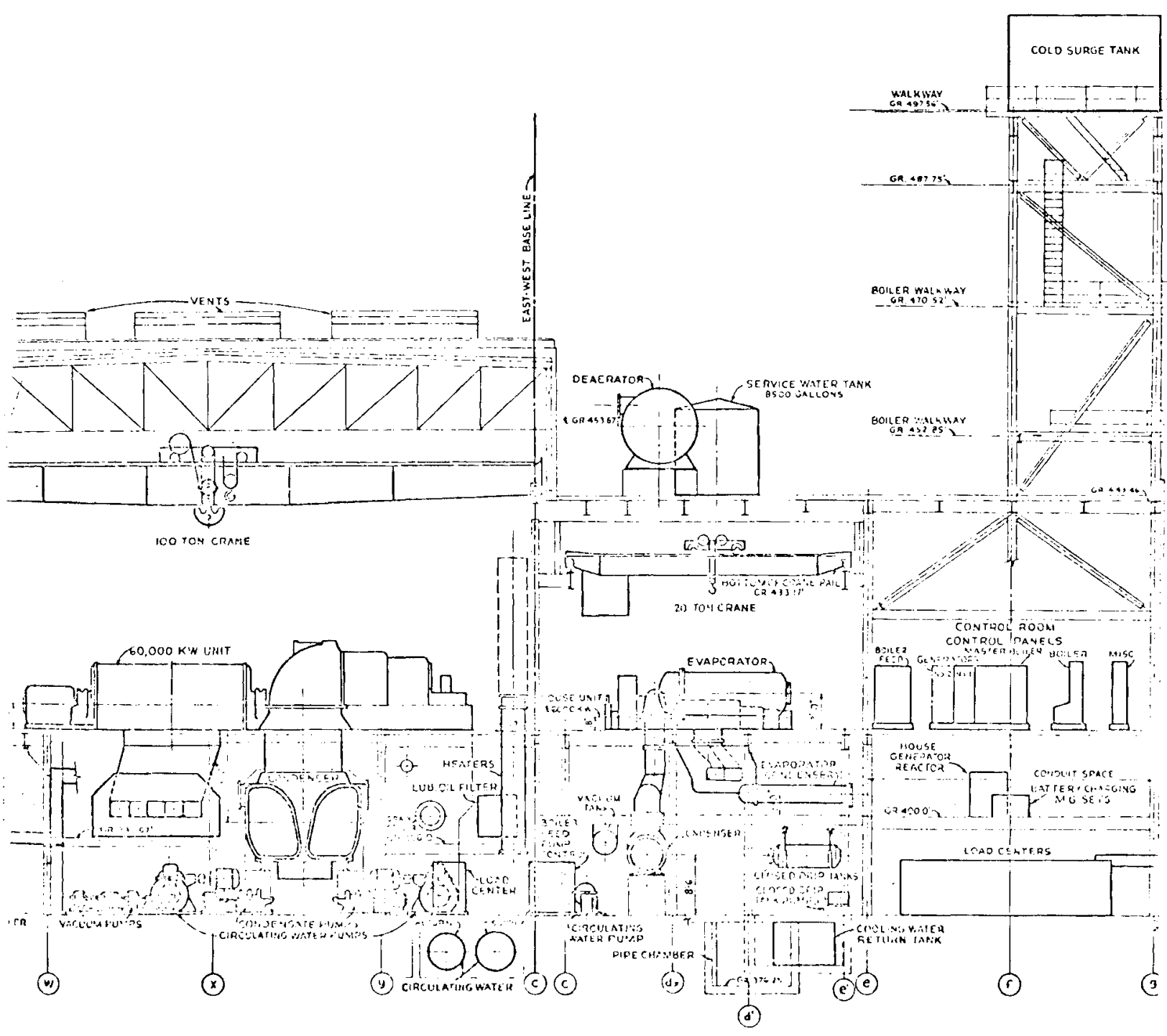

FIGURE 2. Kern Plant: Partial Elevation 


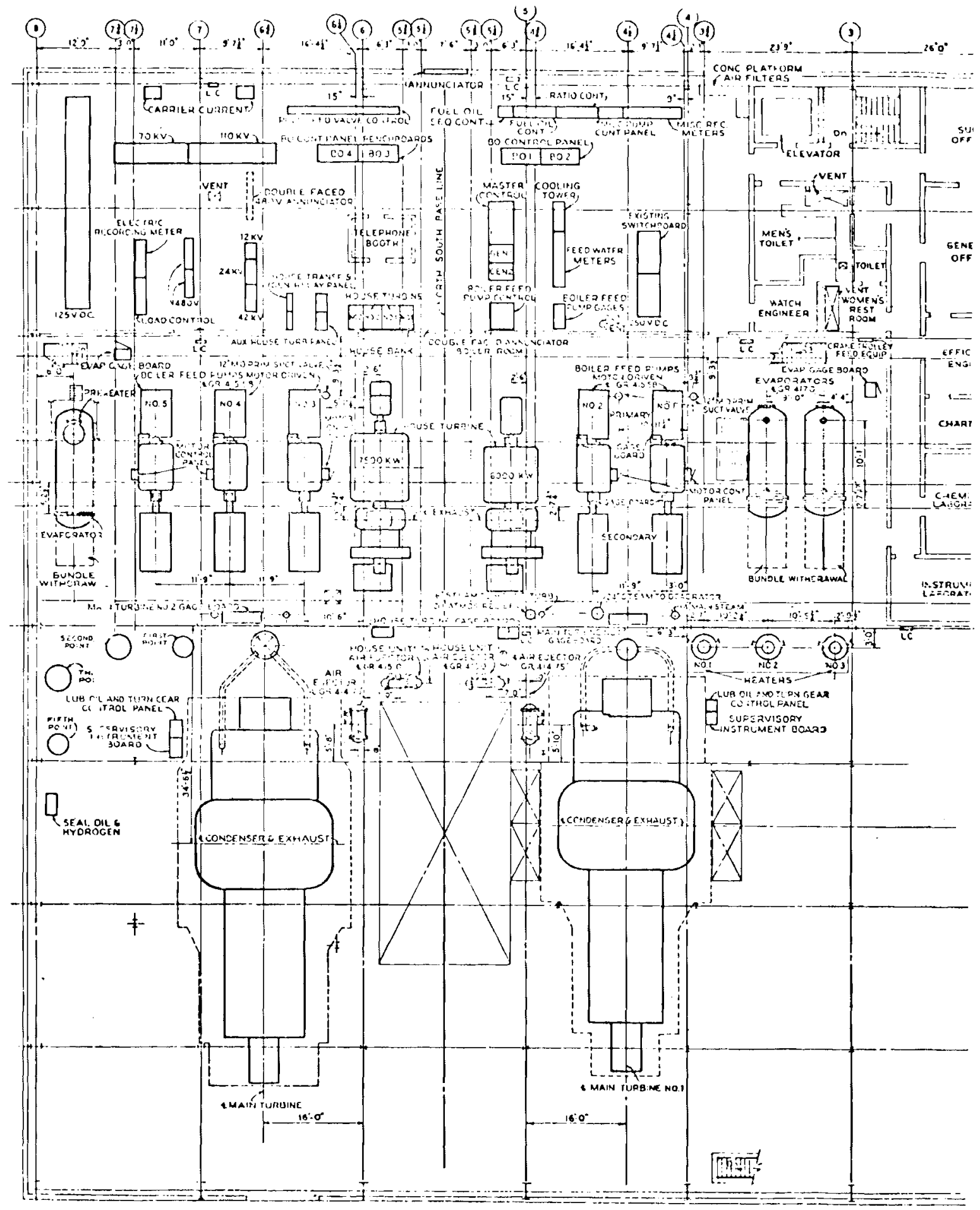

FIGURE 3. Kern Plant: Plan, Grade $412.00 \mathrm{ft}$. 
operational requirements. If steam availability is reduced to the deaerating heater from the house turbine extraction port, it will be offset by obtaining additional steam from a co-source, i.e., flash steam from the boiler blowdown.

Because the Kern Plant is one of the older plants on the PG\&E system and has an unattractive heat rate in comparison to newer plants, it is maintained in a cold standby condition, and only operated during periods of peak demand. It was last operated during the summer of 1976. Most of the demonstration testing will probably be performed on the facility during intervals of scheduled plant operation. However, if this is not feasible, the plant may be run especialiy for the purpose of the testing.

Demonstration tests will range in duration from several hours to several weeks. The demonstrations will include numerous facility startups and shutdowns and procedures designed to mitigate the consequences of unusual events. Between tests and during scheduled facility shutdown periods, the No. 1 house turbine may be either shut down or operated with the existing service condenser, at the option of the plant operating personnel. Appendix B provides a preliminary analysis of the demonstration tests.

Because this facility is a test facility and not a power production facility, it will be monitored closely during periods of operation. The degree of equipment and control redundancy normally associated with power facilities is not required since the effect of any observed failure can be mitigated by immediate facility shutdown.

\section{WATER SOURCE AND QUALITY}

Water is supplied to the plant by three wells with capacities of $1,200,1,400$ and $1,700 \mathrm{gpm}$. Normally only two wells are required for full plant operation. Water from the wells is stored in a 750,000-gallon tank to the west of the turbine room. Water from the wells is sampled and analyzed monthly; the analys is for July and August 1976 is included in Appendix C. 
Waste water is disposed of in an open waste water drain pond near the southwest corner of the site.

\section{EQUIPMENT AND ARRANGEMENT OF DEMONSTRATION FACILITY}

The facility layout is shown in drawings in Appendix D. General piping diagrams of the facility are also shown.

The facility will consist of ten major items of equipment:

1. deaerating steam condenser/ammonia reboiler with separate or integral ammonia vapor separator

2. steam condensate vacuum pump

3. condensate return pump

4. wet/dry water deluge cooling tower

5. ammonia condensate return pump

6. reboiler recirculation pump

7. drain and fil1 pump

8. ammonia storage vessels

9. deluge and rinse water pumps

10. water treatment facility.

The facility will be located outside and downwind of the power station main structure. Exhaust steam from the unit house turbine will be brought out through the east wall of the power station to the condenser/reboiler. The condenser/reboiler will be mounted outside on a concrete slab. Also mounted on this slab will be 1) the condensate return pump, 2) the mechanical deaerater, and 3 ) the reboiler recirculating pump.

The ammonia vapor from the reboiler will be brought to the facility cooling tower by an underground pipeline. The cooling tower will be located to the south of the main plant tower in an area east of the plant main gate. $A$ concrete slab will be provided for 1) the ammonia condensate return pump, 2) the delugeate recirculating pump, and 3) the wash pump. The condensed 
ammonia from the facility cooling tower will be returned to the condenser/ reboiler in an underground line.

The delugeate and rinse water storage tanks will be located near the facility cooling tower. A metal building will be provided for the water treatment equipment.

The ammonia storage tank will be located approximately $350 \mathrm{ft}$ east of the cooling tower adjacent to a paved road and railroad tracks. A drainfill pump will be provided to pump ammonia to the system.

Electrical power for the facility will be supplied from an outdoor electrical load center located at a convenient location on or adjacent to the condenser/reboiler foundation slab. The supply source for this load center will be the plant equipment load center located on grade $386 \mathrm{ft}$.

\section{Condenser and Vacuum System}

The exhaust steam from the 6,000-kW, No. 1 house turbine will be brought to the condenser/reboiler, mounted on grade $386 \mathrm{ft}$ outside of the power station near column lines 1 and $d x$. The line carrying this exhaust steam will be connected to the existing turbine exhaust duct which will be field modified to provide the required branch tap and transition. The exhaust steam pipe is brought out through the east wall of the plant at approximately grade $400 \mathrm{ft}$, with an elbow provided to direct the steam to the entrance nozzle on the top of the condenser/reboiler.

The condenser/reboiler will be a return flow shel1-and-tube unit with condensing steam on the shell side and forced-circulation evaporating ammonia in the tubes. It will be a deaerating type with integral hot well. The tube will be fabricated of aluminum with an interior 0.025-in. coating of the Linde "PBS" material. Tubes in the deaerating section will be stainless steel. Air will be evacuated through the air removal nozzle of the condenser/reboiler by a vacuum pump unit mounted adjacent to the condenser/ reboiler.

The condensate from the hot well will be returned to the inlet of the No. 5 heater of Unit 1 by a centrifugal pump mounted beneath the condenser. A control system will be provided to maintain a preset level in the condenser hot well. 
Ammonia Heat Transport System

The ammonia heat transport system is a two-phase evaporation-condensation system which carries the heat transferred to it in the condenser/ reboiler to the cooling tower where it is discarded to the environs.

The ammonia side of the condenser/reboiler will be designed for forced circulation boiling with the capability of varying the average discharge vapor quality at the outlet of the tubes from $50 \%$ to $80 \%$ at full turbine load conditions. The ammonia vapor-liquid mixture from the condenser/reboiler will be discharged into a vapor separator where the ammonia vapor will be disengaged from the mixture and the saturated liquid returned to the reboiler recirculation pump. A flow restricter provided at the entrance of the reboiler will allow for the adjustment of flow to produce qualities in the desired range.

Ammonia vapor from the vapor separator will be carried to the cooling tower by an underground pipe line approximately $250 \mathrm{ft}$ in length. This pipe will be generally sloped toward the cooling tower and provided with traps at intervals. The traps will discharge to the collection line which drains into the cooling tower ammonia hot well.

The cooling tower will be provided with a hot well to collect condensate from the heat exchanger sections. This ammonia condensate will be returned to the ammonia condenser/reboiler by a centrifugal pump located beneath the ammonia hot well. A control system will be provided to regulate the level of ammonia in the hot well at the desired level. The ammonia condensate will be returned by an underground pipe line.

\section{Coaling Tower}

The ammonia vapor will be condensed in an induced draft, direct condensing cooling tower. The tower will be provided with two sets of heat exchangers of different types: 1) the Forgo plate fin-tube heat exchanger and 2) the Curtiss-Wright "chip-fin" heat exchanger. When operating with either heat exchanger sets, the tower will have a "dry" design capacity of $61.2 \times 10^{6}$ BTU/HR when operating with $125^{\circ} \mathrm{F}$ ammonia and with an ambient temperature of $55^{\circ} \mathrm{F}$. 
When ambient temperatures exceed $55^{\circ} \mathrm{F}$, the tower capacity will be water augmented. When the Forgo system is in service, the augmentation will be accomplished by deluging the vertical fins of the heat exchanger sections. When a section is deluged, the fins of that section will be covered with a continuous film of water. The heat transfer to the air will occur by a combination of two mechanisms. The first mechanism is the convection of sensible heat to the air from the surface of the thin water film. The second mechanism is the transfer of latent heat by evaporation from the surface of the film. Since the film is continuous, deposition of minerals is unlikely because there is no dryout on the surface. During conversion from the wet to dry operation, the heat transfer surfaces are rinsed with zero-hardness water to limit the possibility of deposition during the ensuing dryout. Generally, the number of heat exchanger sections being deluged will be increased as ambient temperature climbs to hold a sufficiently low turbine backpressure while limiting water concumption and, conserving pumping power necessary to supply the delugeate.

When the Curtiss-Wright heat exchangers are in service, the augmentation will be accomplished through the use of a water-cooled, shell-and-tube, ammonia condenser. This condenser will be designed to condense $30 \times 10^{6} \mathrm{lb} / \mathrm{hr}$ of ammonia at $125^{\circ} \mathrm{F}$. It will be cooled by means of recirculating cooling water from the existing plant cooling towers. The quantity of ammonia vapor supplied to the augmentation condenser will be regulated to limit ammonia system pressure to some preset value.

At the higher ambient conditions, the turbine back pressure can be allowed to climb to a maximum of $7.5 \mathrm{in}$. $\mathrm{Hg}$ before turbine load is decreased to limit the possibility of turbine damage, although the demonstration tower is designed to maintain the pressure below $5.0 \mathrm{in}$. for all temperatures anticipated at Bakersfield.

A reheating hot well will be provided to collect the ammonia condensate from the heat exchangers and the augmentation condenser. A bypass line from the ammonia vapor header to the hot well will reheat the condensate which may have been undercooled in the horizontal tubes of the heat exchangers. 
Valves will be provided to isolate the unused heat exchanger set while the other is in service.

Water Treatment Facility

The three plant wells have an excess capacity of 1,000 gpm. The deluge water treatment will consist of sulfuric acid addition to control pH (7.6 to 7.8 based on experimental evidence). Blowdown will maintain a sufficiently low dissolved solids concentration. The blowdown is discharged to the existing plant waste pond. Whenever the tower is changed from wet to dry operation, heat exchanger surfaces will be flushed with zero-hardness water for 5 minutes. Water containing less than 5 ppm calcium as $\mathrm{CaCO}_{3}$ is produced by passing excess deluge makeup water through a sodium zeolite water softener. This softened water will be stored in a 4,000-gallon tank located near the cooling tower.

\section{Ammonia Storage}

Pressure ammonia storage vessels and a tank truck unloading station will supply and store an inventory of liquid ammonia for the test facility. The storage tanks will be located to the east of the cooling tower adjacent to a paved road. A fill pump will pump liquid ammonia to the system. The location and orientation of the tanks will facilitate offloading of anhydrous ammonia from rail cars on the plant siding, or from tank trucks. Connections will be provided to pump from either a truck or railroad car.

\section{Evacuation and Purge System}

An evacuation system will be provided to remove gaseous impurities from the ammonia heat transport system. Purge lines will be provided for the reboiler vapor separator, cooling tower header and ammonia hot well. These lines will have solenoid-operated valves and will be combined into a common line. This line will terminate at a 3,000-gallon aqueous ammonia tank located near the ammonia storage facility. Here the waste ammonia being carried with the impurities will be introduced into water or a weak ammonia solution where it will be dissolved. The resulting aqueous ammonia can be either discarded or sold for fertilizer. 
A vacuum pump will remove air from the system before charging it with ammonia.

\section{Vent System}

The exhaust steam pipe will be provided with a positive pressure relief outside the plant main structure to vent $60,000 \mathrm{lb} / \mathrm{hr}$ steam to the environment in the unlikely event of a test system malfunction. A rupture disk or other approved method will be used.

The ammonia heat transport system and ammonia storage tanks will have pressure relief valves, set to protect the ammonia piping and vessels from overpressurization in the unlikely event of a component malfunction. The ammonia vapor vents will header into a common line which will terminate at the waste aqueous ammonia storage tank, similar to the evacuation and purge system.

\section{Controls}

The power plant control room will house a panel containing controls, process instrumentation and alarms (specified in Section 7).

Automatic controls include the following:

- Condenser/reboiler hot well level control

- Ammonia vapor separator level control

- Ammonia hot well level control

- Tower fan control (sequential fan startup as ammonia system approached the operating point, i.e., below 306 psia)

- Deluge valve control (sequential section startup for pressures above specified ammonia system control pressure)

- Augmentation condenser ammonia admission valve

The facility's cooling tower rinse cycle will be manually controlled from the control room. 


\section{Test Instrumentation}

The instrumentation sensors specified in Section 7 are provided to obtain and record data on the operation of the facility under all operating conditions. An automatic data acquisition system capable of unattended operation will scan, read and record all data specified. 


\section{CODES AND STANDARDS}

A11 construction, operation, and testing of this facility will be in strict conformance with all State and Federal Construction Codes and Standards and all safety and health codes and standards to specifically include OSHA and CAL OSHA.

\section{Civil and Structural}

American Concrete Institute (ACI)

ACI 301-72(R-1975) Structural concrete for buildings

American Institute of Steel Construction (AISC)

AISC-1970(R-1973) Manual of steel construction (7th edition)

American Society for Testing and Materials (ASTM)

A36-75 Structural steel

American Welding Society (AWS)

AWS D1. 1 (Rev. 2-77) Structural welding code

International Conference of Building Officials (ICBO)

Uniform building code (1976 edition)

American Association of State Highway and Transportation Officials (AASHTO)

T180-74 Moisture density relations of soils using the 1016 rammer

and 18-in. drop

T26-72 Quality of water to be used in concrete.

Mechanical

American National Standards Institute (ANSI)

A13.1-1975 Identification of Piping Systems

B9.1-1971 Safety Code for Mechanical Refrigeration

B16.5-1973 Steel Pipe, Flanges, Flanged Valves

B31. 1-1977 Power Piping

B36.10-1977 Welded and Seamless Wrought Steel Pipe

K61.1-1977 Safety Requirements for the Storage and Handling of Anhydrous Ammonia 
American Society of Mechanical Engineers (ASME)

Boiler and Pressure Vessel Codes (1974 \& Rev. thru 1976)

Performance Test Codes (Rev thru 1976)

American Society for Non-Destructive Testing (ASNT)

SNT-TC-1A Personne1 Qualifications and Certification in Non-Destructive Testing

American Society for Testing and Materials (ASTM)

A533-76 Pipe, Steel, Black and Hot Dipped, Zinc Coated, Welded and Seamless

A-106-76a Seamless Carbon Steel Pipe for High Temperature Service

A-134-74 Electric Fusion (ARC) - Welded Steel Plate Pipe

A-182-76a Forged or Rolled Alloy-Steel Pipe Flanges, Forged Fittings and Valves and Parts for High Temperature Service.

C-450-68 Prefabricated and Field Fabrication of Thermal Insulating Fitting Covers for NPS Piping, Vessel Lagging and Dished Head Segments

Instrument Society of American (ISA)

SP-1-1973 Instrumentation Symbols and Identification

RP-7.1-1956 Pneumatic Control Circuit Pressure Test

\section{Electrical}

National Electrical Manufacturers Association (NEMA)

ICS 1970 Industrial Controls and Systems (Rev. thru 1976)

SG6-1974 Power Switching Equipment

WDI-1974 General Purpose Wiring Devices

Underwriters' Laboratories, Inc. (UL)

Electrical Construction Materials List (1978)

Occupational Safety and Health

US Department of Labor, Occupational Safety and Health

Title 29 CFR 1910 0ccupational Safety and Health Standards

Title 29 CFR 1926 Safety and Health Regulations for Construction 


\section{ARCHITECTURAL AND STRUCTURAL DESCRIPTION}

\section{REBOILER BUILDING}

The foundation of the reboiler structure will consist of a reinforced concrete slab at grade $386 \mathrm{ft}$. The foundation slab will hold the cradle supports for the reboiler and foundations for the condensate return pump, ammonia recirculating pump, deaerating unit and the facility's electrical load center. The foundations and supports will be positioned on the foundation slab so that adequate clearance is available for removal of the reboiler shell cover and floating head cover and withdrawal of the tube bundle. Adequate clearance will also be provided for removing pumps.

Structural steel framework will be provided on the reboiler building foundation slab to support the roof structure. The roof will be metal with sufficient slope to ensure drainage and of sufficient size to cover the foundation slab. There will be no walls or enclosures which might trap ammonia fumes.

\section{COOLING TOWER}

The cooling tower wi11 be located approximately $250 \mathrm{ft}$ east of column line 2 along coordinate North 1200. The foundation slab for the pumps associated with the cooling tower will be located adjacent to the cooling tower footings. Figures 4 through 7 show four different perspectives of the cooling tower.

The cooling tower will be placed on independent spread footings under each support column. The area immediately under the cooling tower will be covered with a 4- to 6-in. concrete slab on grade. This slab will be sloped as indicated in Figures 6 and 7 to a dry well of sufficient capacity to disperse incidental tower water leakage and splash.

The foundation slab for the pump associated with the cooling tower will be reinforced concrete provided with a pit for the condensate return pump. This pit will have a sump pump and curbing around its periphery. 


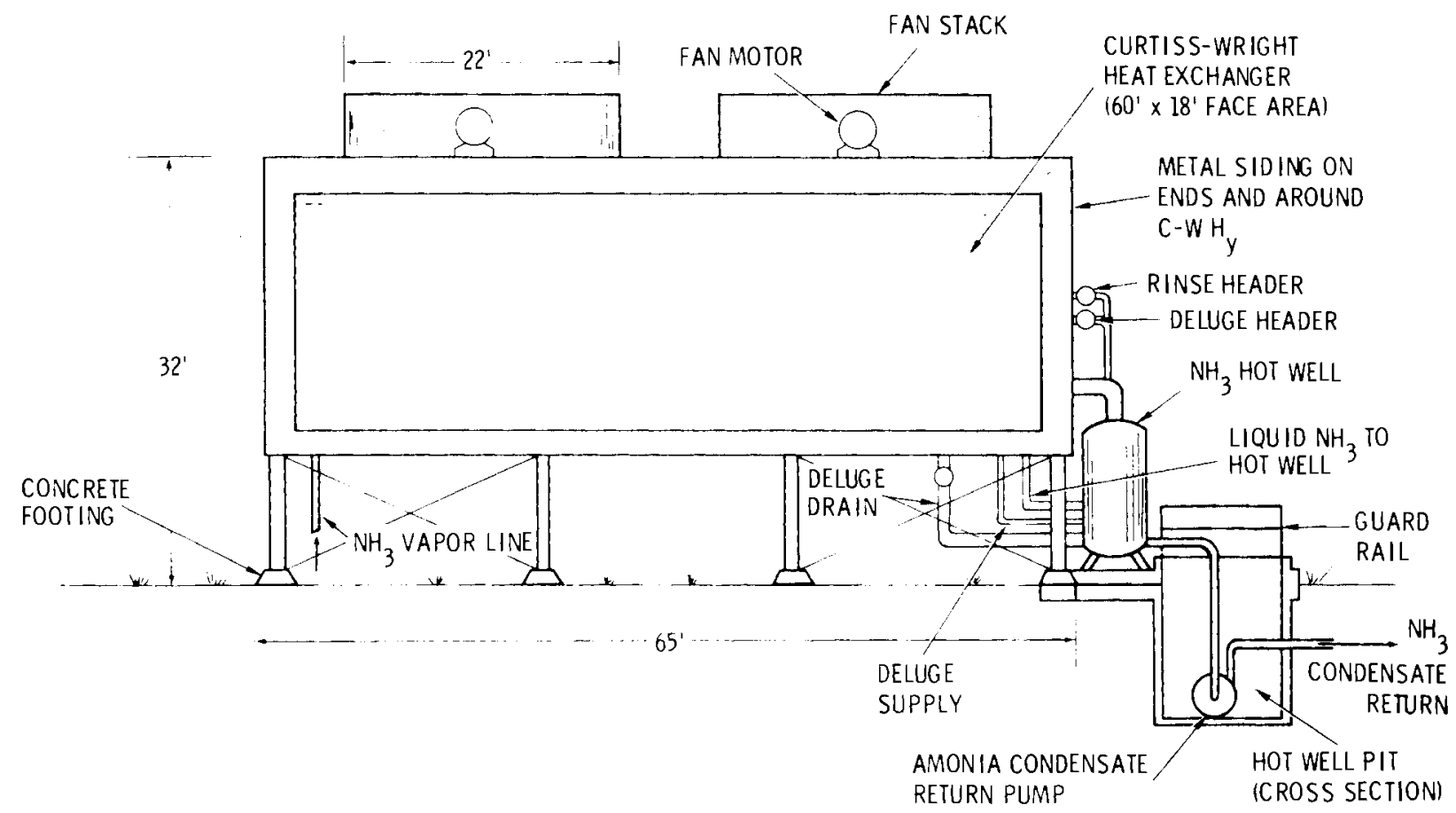

FIGURE 4. Cooling Tower Elevation

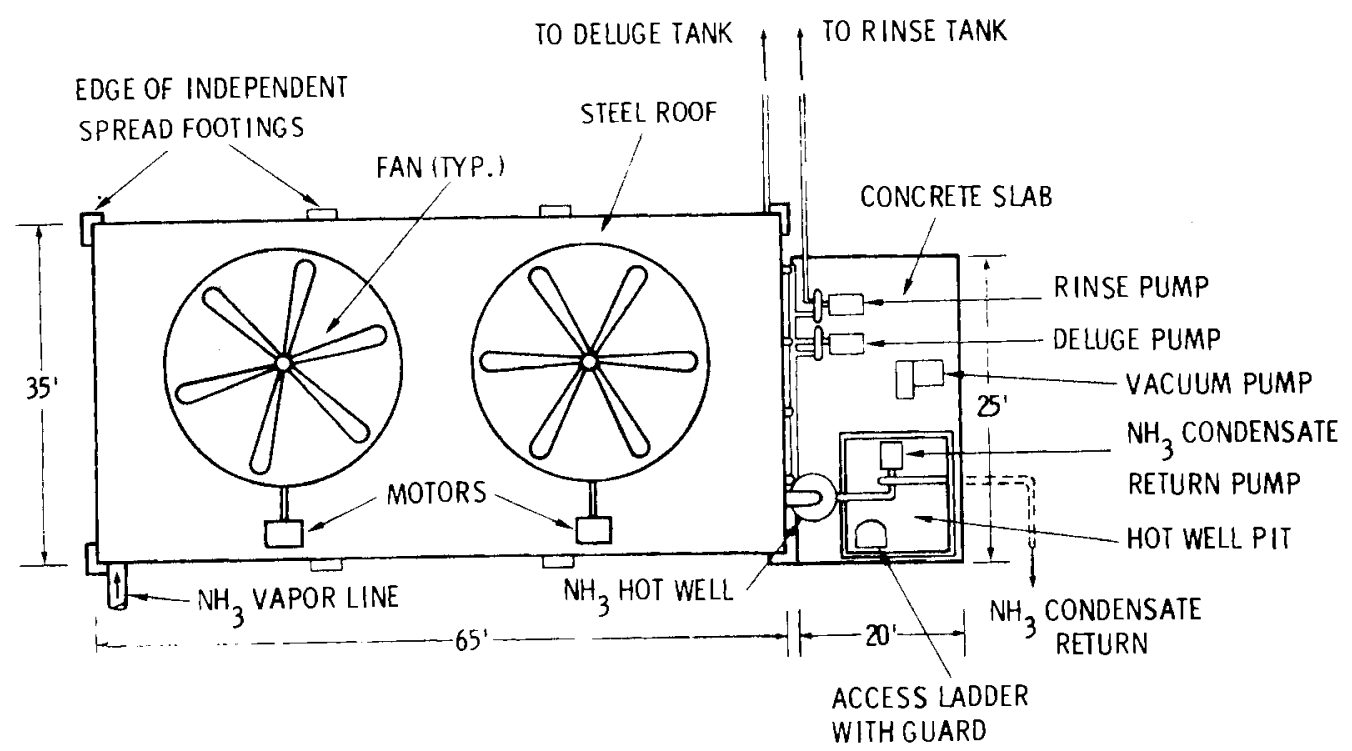

FIGURE 5. Cooling Tower: Plan View 


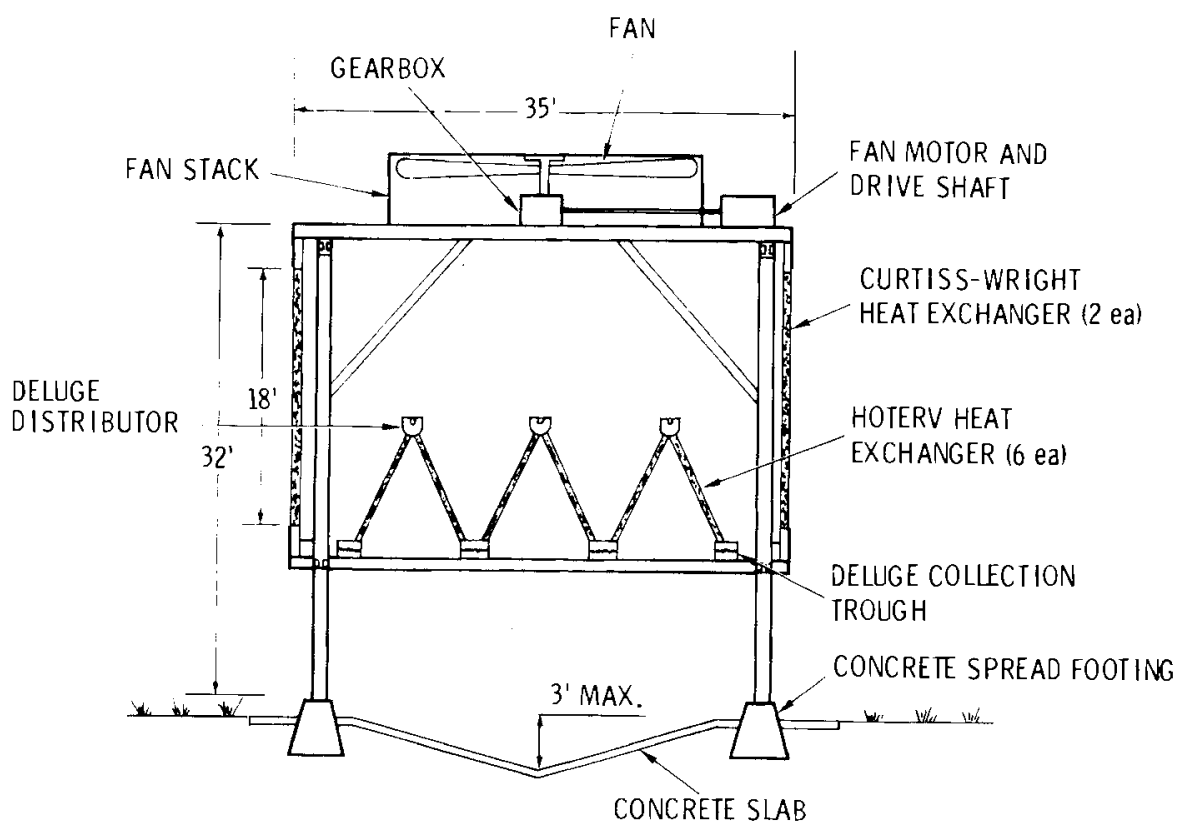

FIGURE 6. Cooling Tower: Typical Transverse Cross Section

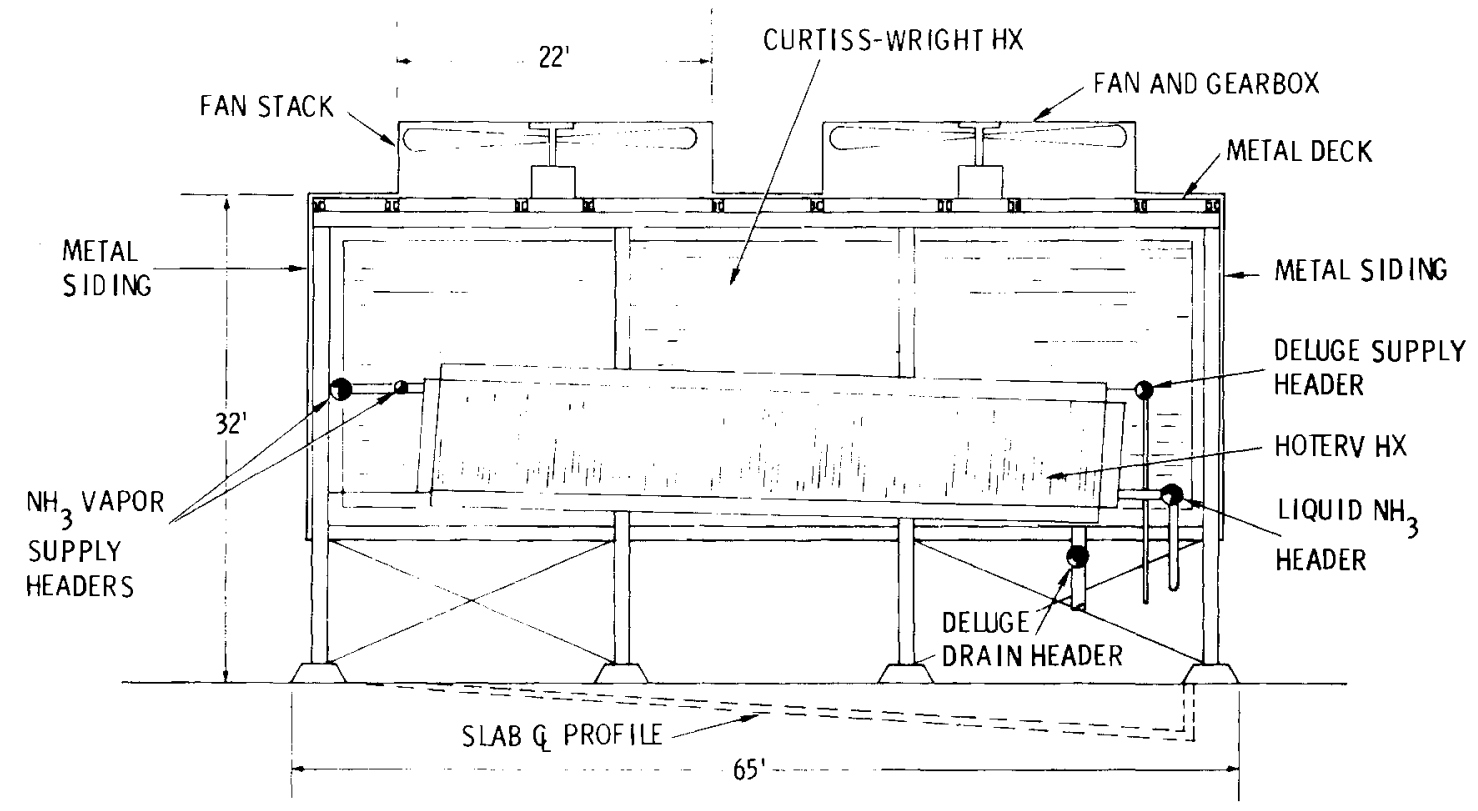

FIGURE 7. Cooling Tower: Typical Longitudinal Cross Section 
A structural steel framework will be provided to support components of the cooling tower. The heat exchangers will be supported from members of this framework. The upper level members support the cooling fans, motors, and fan stacks.

The framework will be sheathed with painted sheet steel siding and provided with a steel roof. A steel floor will close off air bypass paths around the heat exchanger. A steel door, located in one side of the sheathed portion of the structure, will allow personnel access.

Steel or plywood panels will be provided to prevent airflow through the unused heat exchanger when the other is in service. Clips or channels will hold the panels in place and will allow for their convenient installation and removal (2 days or less).

The ammonia condensate pump pit will be provided with a steel access ladder and railings.

A11 steel work will be painted to resist rusting in the moist atmosphere produced by the cooling tower during deluging.

\section{WATER TREATMENT FACILITY}

A steel building on a concrete slab foundation will house the water treatment equipment described in Section 5 . This building will have approximately $250 \mathrm{ft}^{2}$ of floor area and will be insulated and heated to prevent freezing. It will be located in the vicinity of the cooling tower. Concrete slab foundations will support the rinse and waste tanks described in Section 5. These will be conveniently located near the facility cooling tower.

\section{AMMONIA STORAGE FACILITY}

Reinforced concrete cradle-type supports will hold a 12,000-gallon anhydrous ammonia storage tank (described in Section 5) east of the plant on coordinate N1200. A concrete slab will be provided to support the fill pump and the 3,000-gallon waste aqueous ammonia storage tank. 
ROADS AND WALKWAYS

All roads, walkways and parking lots currently located at the Kern plant will be used during construction and operation of the test facility. 


\section{MECHANICAL DESCRIPTION}

\section{EXHAUST STEAM DIVERSION LINE}

A 48-in.-diameter diversion pipe will exhaust steam from the existing duct of the Unit 1 house unit to the shell side of the condenser/reboiler unit. This line will be designed for $60,000 \mathrm{lb} / \mathrm{hr}$ saturated steam at $4.5 \mathrm{in}$. Hg with a pressure loss of $0.1 \mathrm{in}$. $\mathrm{Hg}$ or less. When steam is being diverted for test facility operation, cooling water will not be supplied to the existing water-cooled condenser.

The existing exhaust duct of the No. 1 house unit will be field modified by cutting a hole approximately $6.5 \mathrm{ft}^{2}$ area in the east side of the duct and welding in a shop-fabricated transition fitting to 48 in. nominal pipe size. The 48-in. diversion 1 ine will be joined to this transition fitting through an expansion joint. This line will proceed eastward and pass through the east wall of the plant between grades 400 and $412 \mathrm{ft}$. Outside of the plant, the line will elbow downwards into the steam inlet of the condenser/reboiler. An atmospheric relief port (flange and rupture disk assembly) on the line at a convenient outside location will prevent pressurization of the turbine and condenser in the unlikely event of a failure of the test facility. Flanged joints at appropriate locations will allow removal of a section of the 48-in. diversion 1 ine to provide clearance for possible removal of the tube bundle from an existing evaporator/condenser located on grade $400 \mathrm{ft}$.

The exhaust steam diversion 1 ine will be insulated with a nonasbestos material to 1 imit surface temperatures to $120^{\circ} \mathrm{F}$ at nominal operating temperature.

\section{STEAM CONDENSER/REBOILER}

The steam condenser/reboiler will be designed to condense $60,000 \mathrm{lb} / \mathrm{hr}$ of saturated steam at $4.5 \mathrm{in} . \mathrm{Hg}\left(130^{\circ} \mathrm{F}\right)$ (nominal) and produce $136,200 \mathrm{lb} / \mathrm{hr}$ saturated ammonia vapor at 307 psia $\left(125^{\circ} \mathrm{F}\right)$. Steam will be condensed on the shell side; ammonia vapor will be produced on the tube side by forced 
circulation. The shell side will be provided with a deaerating hot well. The tube side will have a vapor separator capable of producing $98.5 \%$ or better ammonia vapor quality at rated load. This unit will be designed to use aluminum tubes which are provided with the (Linde proprietary) enhanced condensation/boiling surface. Performance data specified by Linde will be modified to include fouling factors on the steam side recommended by TEMA standards. Table 1 gives the specifications of the condenser/reboiler.

\section{CONDENSATE RETURN SYSTEM}

A hot-wel1 pump will return the steam condensate from the condenser/ reboiler hot well to the inlet of the No. 5 heater of Unit 1. This pump will have the same or greater head and capacity rating as one of the existing hot-wel1 pumps associated with the Unit 1 house condenser. There wi11 be no spare pumps.

Al1 piping associated with the condensate return system will be 3 -in. Schedule 40 or larger unless otherwise determined. The condensate pump will take its suction directly from the bottom of the condenser/reboiler hot well. A bleed line and flow control valve will be located on the discharge of the pump. The bleed line will be designed with an appropriate hydraulic resistance to allow a small cooling flow (5-10 gpm) to return to the hot well when the flow control line is closed. The flow control valve will have an air operator complete with the hot-well condensate level controller specified in Section 7 . A check valve will be provided to prevent reverse flow into the hot well if the condensate return pump should fail. Downstream of the check valve, a diversion tee and valves will enable the diversion of the condensate to the waste water drain pond if the reboiler tubes should fail. These valves will have electric/pneumatic operators and will be operated from the control room as described in Section 7. The diversion branch will discharge to an existing waste line at the nearest convenient location. The condensate return piping will discharge into the existing hot-well pump discharge piping. 
TABLE 1. Condenser/Reboiler Specification Sheet

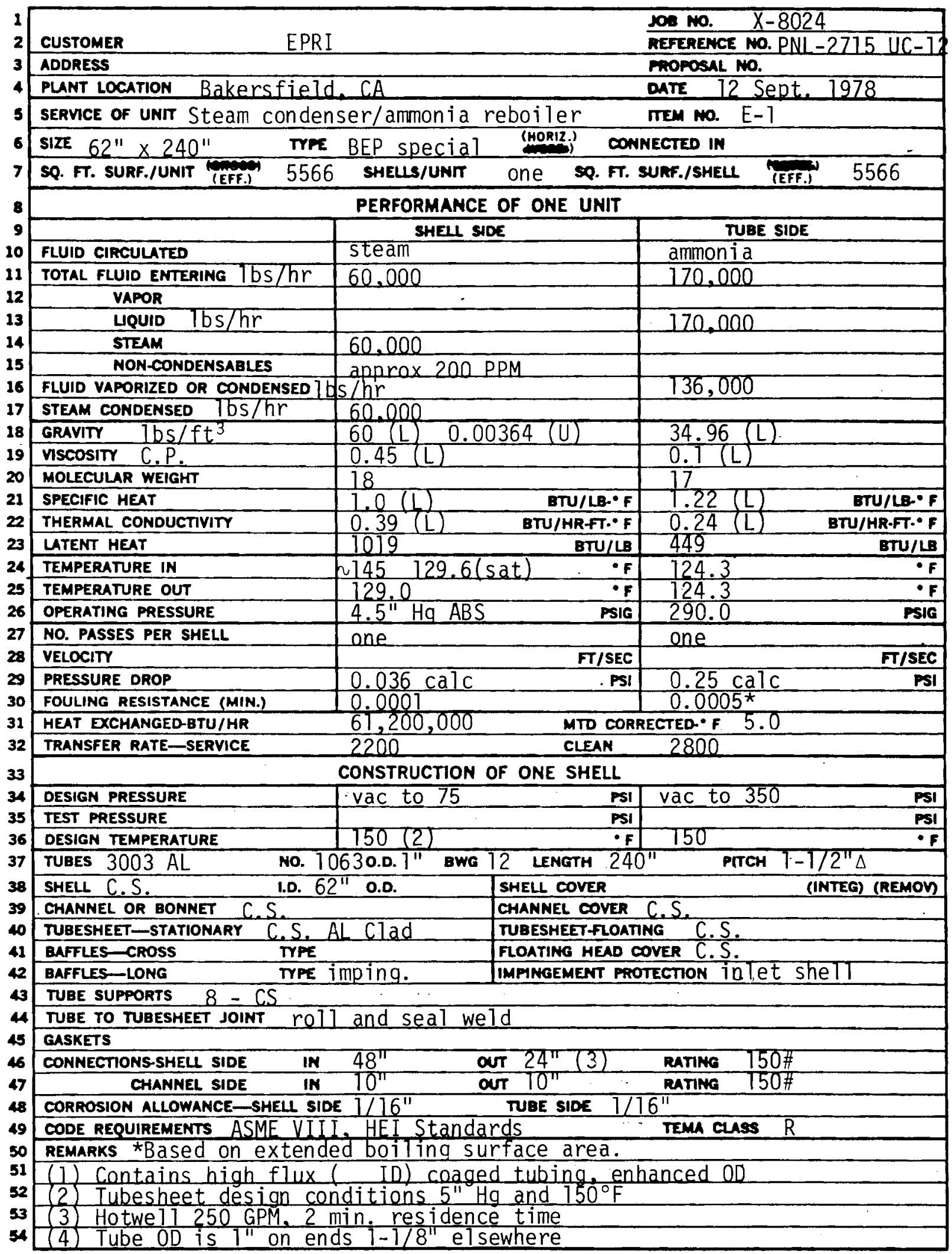


A mechanical vacuum pump type deaerator will remove noncondensibles from the condenser/reboiler. This deaerator will be rated for $45 \mathrm{lb} / \mathrm{hr}$ of air/vapor mixture with $30 \%$ dry air content by volume. The electric driving motor will be approximately $2 \mathrm{hp}$.

\section{REBOILER NH${ }_{3}$ RECIRCULATION SYSTEM}

A centrifugal or mixed flow pump will circulate the ammonia through the tubes of the reboiler. This pump will be designed to supply $607 \mathrm{gpm}$ of liquid ammonia at $125^{\circ} \mathrm{F}$ against a total system hydraulic resistance of $55 \mathrm{ft} \mathrm{NH}_{3}$, including reboiler tube side resistance (approximately $0.25 \mathrm{psi}$ ), the separator (approximately 1 psi), system piping and valves (approximately $9.5 \mathrm{psi}$ ) and the reboiler inlet flow restrictor. The pump will be double mechanically or hermetically sealed for ammonia application.

Ammonia recirculation piping will be designed for maximum system pressure of $350 \mathrm{psi}$ and $150^{\circ} \mathrm{F}$. Materials for piping will be seamless carbon steel (ASTM A-53, Grade B or ASTM A-139). Fittings will be carbon steel ASTM A-234, ANSI B16.9 or MSS SP-48. Valves will be carbon steel, API 6D modified for anhydrous ammonia service. Piping in the recirculating system will be all welded construction.

The recirculation piping system will take saturated ammonia from the reboiler separator, combine it with ammonia condensate returning from the cooling tower and deliver the mixture to the suction of the recirculating pump. The recirculating pump will discharge into the inlet of the reboiler through a flow restrictor. The purpose of this restrictor is to introduce sufficient hydraulic resistance into the system so that the recirculation rate remains relatively constant $( \pm 5 \%)$ regardless of the amount of vapor generation in the reboiler. This restrictor will be sized to permit the recirculation pump described earlier to deliver the specified flow rate to the reboiler at normal system operating conditions. Globe valves will be provided to isolate the recirculation pump for maintenance. 


\section{AMMONIA VAPOR EXPORT PIPING}

The ammonia vapor export line will be designed to carry 136,000 1b/hr of saturated ammonia vapor from the reboiler separator to the cooling tower vapor distribution headers with a pressure loss of 2.5 psi or less. It will be constructed from carbon steel and designed for service at 350 psi and $150^{\circ} \mathrm{F}$. The vapor export line will be routed below ground.

The vapor export lines will be insulated with a nonasbestos mineral or foam glass to limit condensation to less than $4 \%$ for the lowest ambient temperature $\left(25^{\circ} \mathrm{F}\right)$ and maximum design flow rate.

The condensate removal system will consist of the traps, drain lines and the ammonia condensate line, which returns the condensate to the cooling tower hot well. This piping subsystem will be constructed from carbon steel and designed for $350 \mathrm{psi}, 150^{\circ} \mathrm{F}$ service. It will be capable of removing and gravity-draining 5,400 $\mathrm{lb} / \mathrm{hr}$ of condensate from the ammonia vapor export line.

\section{AMMONIA RETURN SYSTEM}

A condensate return pump will return the saturated or slightly subcooled ammonia condensate from the cooling tower hot well through an underground pipe to the reboiler recirculating loop. This pump will be designed to return $136,000 \mathrm{lb} / \mathrm{hr}$ of liquid ammonia through the condensate return line against the head determined by the elevation of the ammonia liquid surface in the separator. The pump will be capable of $150 \%$ of rated capacity for short intervals to accommodate surges and starting transients. The pump will be double mechanically or hermetically sealed for ammonia application.

The pump will be mounted in the cooling tower condensate return pit at an elevation that maintains the manufacturer's recommended suction head for the specified over capacity condition.

A fan will be provided to introduce positive and reliable ventilation to the condensate return pit. This fan will be installed in accordance with NFPA 30-1973, "Flammable and Combustible Liquids Code," and will have sufficient capacity to provide the required air changes to maintain the ammonia vapor concentration below 25 ppm during normal operation. 
The condensate return pump will take liquid ammonia from the bottom of the cooling tower hot well and discharge it to the condensate return line through the control valve. This valve will be air or electric operatorcontrolled by a level controller and will regulate the discharge of the condensate back to the vapor separator through the condensate return 1 ine. This valve will maintain a constant flow through the condensate return pump by diverting a portion of the flow back to the condensate hot well. The size of the diversion 1 ine will be selected such that its total frictional resistance is approximately equal to the condensate return line.

Positive shut-off valves will be provided to isolate the condensate return pump. A11 lines will be seamless carbon steel and all welded construction.

\section{COOLING TOWER}

The ammonia vapor wil1 be condensed in an induced draft, direct condensing tower. This tower will contain two independent heat exchangers of different types to enable their evaluation during the testing phases of the DCE Program.

The general arrangement of the tower is indicated in Figures 4 through 7 . Located on the long vertical sides of the tower will be two heat exchangers using Curtiss-Wright "chip-fin" aluminum tubing. On the elevated floor of the tower will be 6 Forgo heat exchangers arranged in 3 "delta" assemblies. Both heat exchangers will be sloped slightly towards the outlet to promote drainage. The amount of slope will be determined by research currently underway. The cooling tower will be designed to condense $136,000 \mathrm{lb} / \mathrm{hr}$ of saturated ammonia at $125^{\circ} \mathrm{F}$ when the ambient temperature is $55^{\circ} \mathrm{F}$. Cooling air will be supplied by two 22-ft diameter fans with controllable blade pitch. The fan system will be able to supply the design air flow rate from ach heat exchanger set operated alone. Metal or plywood panels will be placed in front of the unused heat exchanger to block off all airflow during tests of the other. Clips or channels will be provided on the tower structure to enable the rapid installation or removal of these panels. 
The Forgo heat exchangers are all-aluminum plate fin units manufactured in Hungary according to a design developed by the HOTERV Institute. Babcock and Wilcox is the U.S. licensee. These heat exchangers are normally manufactured in modules $5 \mathrm{~m}$ long and approximately $2-1 / 2 \mathrm{~m}$ high. To allow deluging, the plates are oriented vertically with tubes running horizontally. In this installation, the condensing ammonia will flow through the tubes. Tube sheets are provided at both ends of each module to allow the end-to-end assembly multiple $5 \mathrm{~m}$ long modules with the tubes in series. The end tube sheets will be fitted with headers to supply ammonia vapor to one end of the assembly and remove the condensate from the other. The plate fins are provided with artificial roughness elements ("turbulators") to enhance the air side heat transfer.

A series of three modules is bolted together to form one unit with a total length of $15 \mathrm{~m}$. The individual tubes are rolled into headers at the ends of the modules, which in turn seal against matching heads of the other modules as the three units are assembled to make up the unit. Two units will be joined together at an angle of $48^{\circ}$ as illustrated in Figures 8 and 9 . A deluge water distribution assembly will be provided at the joined edge and a collection trough at the bottom. The deluge distribution assembly will consist of an enclosure containing a series of low-pressure spray nozzles or orifices that distribute the deluge water uniformly over the surface of a packing material at the rate of $8 \mathrm{gpm} /$ meter. The purpose of this packing is to transfer the deluge water to the fin surfaces uniformly and without waste. The collection trough will be wide enough to collect the residual water from the bottom of two heat exchanger "delta" assemblies located side by side.

The tower will contain three "delta" assemblies positioned side by side. Each heat exchanger will have a header assembly on both ends. The header will be constructed from carbon steel and have a flanged connection. A purge tap will be provided at the lowest point of each header; all taps will be connected together into a common line. Typical design parameters of the heat exchangers are given in Table 2 . 


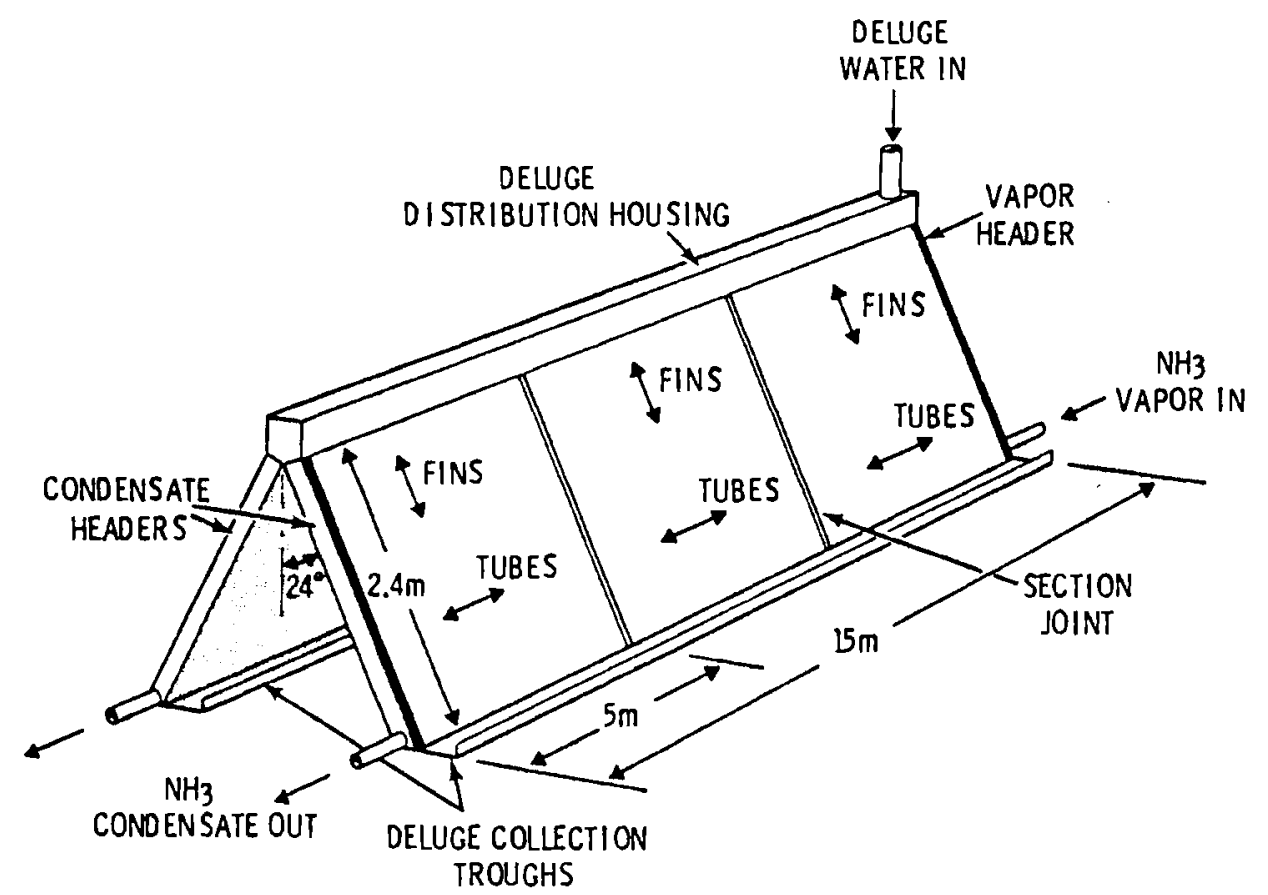

FIGURE 8. Forgo Heat Exchanger Assembly

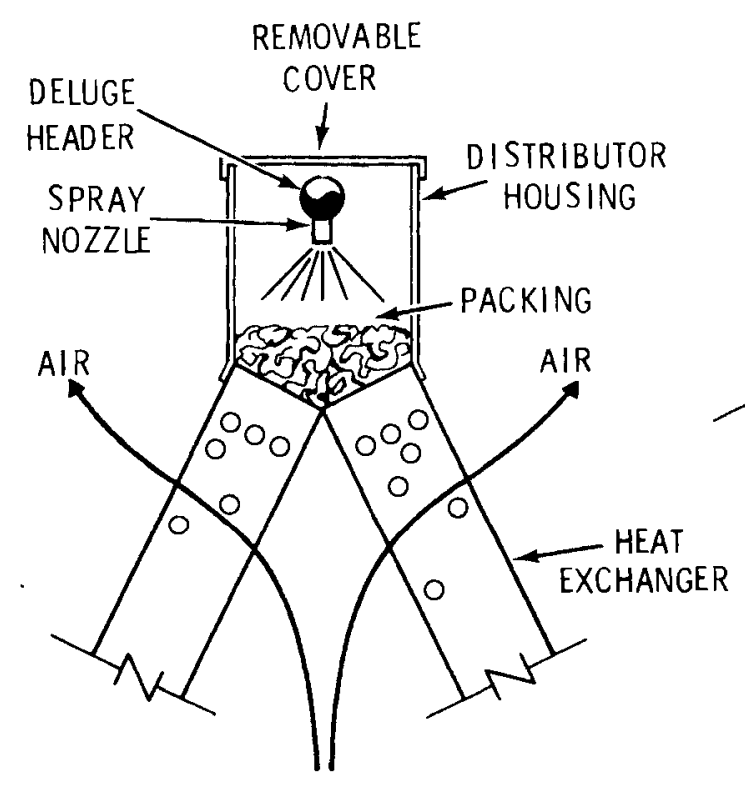

DELUGE DISTRIBUTOR:

TYPICAL CROSS SECTION

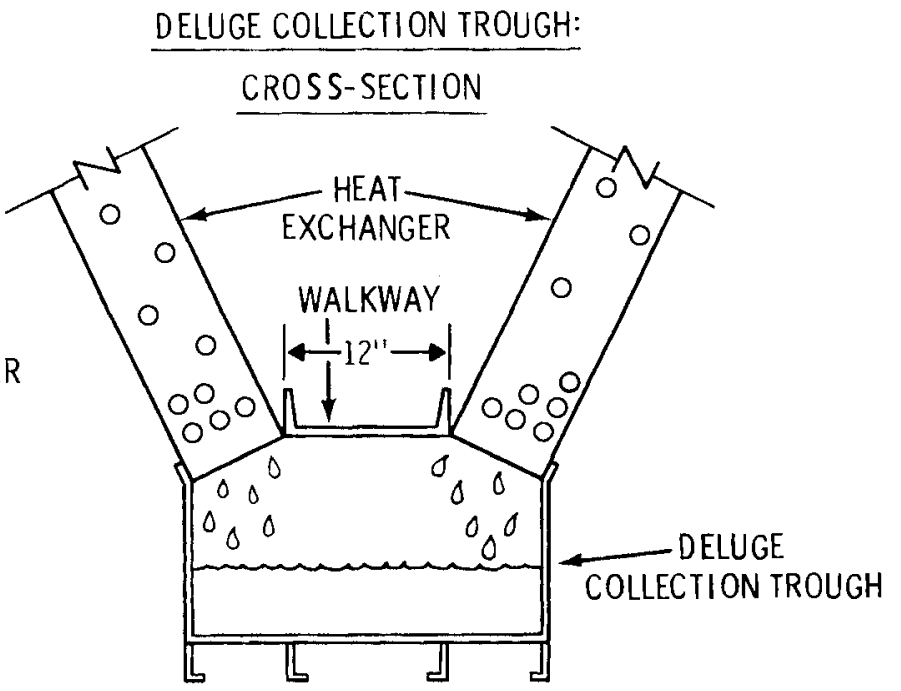

FIGURE 9. Forgo Heat Exchanger Delugeate Distribution 
TABLE 2. Forgo Heat Exchanger Design Parameters

$\begin{array}{ll}\text { Heat Duty: } & 61.2 \times 10^{6} \mathrm{Btu} / \mathrm{hr} \\ \text { Ambient Air Temperature: } & 55^{\circ} \mathrm{F} \\ \text { Ammonia Vapor Temperature: } & 125^{\circ} \mathrm{F} \\ & 70^{\circ} \mathrm{F} \\ \text { ITD: } & 5.28 \times 10^{6} \mathrm{lb} / \mathrm{hr} \\ \text { Total Airflow Rate: } & 0.48 \mathrm{in} . \mathrm{H}_{2} \mathrm{O} \text { (including turning loses) } \\ \text { Airside Pressure Loss: } & 700 \mathrm{gpm} \\ \text { Deluge Flow Rate: } & 150\end{array}$

The Curtiss-Wright heat exchangers will be fabricated from extruded "chip-fin" tubing manufactured by the process developed by Curtiss-Wright corporation. The important dimensions of the tubing selected for this application are summarized in Table 3.

TABLE 3. Chip-Fin Tubing Description

$\begin{array}{ll}\text { Material } & \text { Aluminum } \\ \text { Fin Height } & 0.707 \mathrm{in.} \\ \text { Fin Thickness } & 0.012 \mathrm{in.} \\ \text { Fin Ditch } & 10.6 \mathrm{fins} / \mathrm{in} . \\ \text { Tube Ditch } & 1.714 \mathrm{in.} \\ \text { Tube Height } & 0.300 \mathrm{in.} \\ \text { Ammonia Channel Size } & 0.216 \mathrm{in.} \times 0.140 \mathrm{in} . \\ \text { Fin Depth } & 6 \mathrm{in.} \\ \text { Tube Length } & 60 \mathrm{in} .\end{array}$

Each Curtiss-Wright heat exchanger will consist of 125 tubes as described in Table 3 mounted side by side on a $1.714 \mathrm{in}$. pitch. They will be welded into headers at both ends and a framework will be supplied to provide support, stiffness and the necessary hoisting points for convenient installation. The tower will contain 2 Curtiss-Wright heat exchangers, each mounted with 
horizontal tubes on one of the long vertical sides of the tower. The design parameters of this heat exchanger set are summarized in Table 4.

TABLE 4. Curtiss-Wright Heat Exchanger Design Parameters

$\begin{array}{ll}\text { Heat Duty: } & 61.2 \times 10^{6} \mathrm{Btu} / \mathrm{hr} \\ \text { Ambient Air Temperature: } & 55^{\circ} \mathrm{F} \\ \text { Ammonia Vapor Temperature: } & 125^{\circ} \mathrm{F} \\ \text { Total Airflow Rate: } & 6.375 \times 10^{6} \mathrm{lb} / \mathrm{hr} \\ \text { Heat Exchanger Pressure Loss: } & 0.13 \mathrm{in} . \mathrm{H}_{2} \mathrm{O} \\ \text { Number of Tubes: } & 250(125 \text { each heat exchanger }) \\ \text { Total Fan Horsepower: } & 120\end{array}$

The 10-in. ammonia vapor line from the condenser/reboiler will emerge from the ground beneath the tower and will enter the tower from below. Tap lines will run from the 10-in. line to each flanged heat exchanger connection. Valves in the tap lines will prevent ammonia vapor from entering the unused heat exchangers.

The condensate from the outlet of each heat exchange unit will be collected by a 4-in. carbon steel pipe header running the width of the cooling tower. This header will discharge into the $\mathrm{NH}_{3}$ hot well. Valves will be placed in the outlet lines to prevent the entrance of liquid ammonia into the unused heat exchangers.

A reheating-type hot well will collect, reheat and store ammonia condensate before it is returned to the condenser/reboiler. It will be capable of reheating 136,200 1b/hr of ammonia from the heat exchanger discharge temperature to within $1^{\circ} \mathrm{F}$ of the saturation temperature. The $\mathrm{NH}_{3}$ hot-well vessel will be rated at $350 \mathrm{psi}$ at $150^{\circ} \mathrm{F}$. It will be sufficiently insulated to limit surface temperature to $120^{\circ} \mathrm{F}$ at the nominal operating temperature. The undercooling characteristics of the heat exchanger will be determined during demonstration testing. The ammonia vapor required for reheating will be obtained from a bypass line around the cooling tower. 
The hot well's storage capacity will be at least 2 minutes at rated operating conditions.

\section{AUGMENTATION CONDENSER}

An ammonia-cooled shell-and-tube condenser will provide additional ammonia condensation capacity for the Curtiss-Wright heat exchangers on warm days. This condenser will have a capacity of 65,000 1b/hr of ammonia at $125^{\circ} \mathrm{F}$. Ammonia vapor will be admitted to the shell side of the condenser from the 10-in. vapor export line through an air-operated valve. This valve will be controlled to maintain a preset pressure on the vapor side of the ammonia system. The condensed ammonia will be returned to the hot well through a float-actuated valve. Water at $80^{\circ} \mathrm{F}$ will be supplied to the condenser tubes from the plant's cooling water recirculation system. Connections will be made to the recirculation system's underground supply and return pipes at the point where the underground facilities' lines pass over/under these pipes.

The condenser will have a carbon steel shell, aluminum tubes and an aluminum tube sheet. The tubes will be rolled and seal welded into the tube sheet.

\section{DELUGEATE SUPPLY SYSTEM}

The deluge pump will take $700 \mathrm{gpm}$ water from the delugeate storage tank and deliver it to the deluge distribution system at a head of approximately $30 \mathrm{ft}$ water (assuming 5 psi spray nozzles in the heat exchanger's delugeate distributor).

The deluge pump will discharge into a common header supplying the heat exchanger delta assemblies. The distribution pipe from each heat exchange delta assembly will be connected to the header through an electrically operated valve to allow selection of partial or complete deluging of the heat exchangers. The distribution pipe in each delta assembly will have a series of low-pressure spray nozzles to produce a uniform application of delugeate to the top of the packing. Excess delugeate being discharged from the bottom of the heat exchanger will be collected in the collection trough 
and returned by gravity to the suction of the deluge pump. A blowdown line will discharge a maximum of $50 \mathrm{gpm}$ to the plant waste water pond via an underground line.

All piping in the delugeate supply will be polyvinyl dichloride (CPVC), class 125.

Raw well water will be taken from the nearest supply source and brought to the facility's water treatment structure. Chemicals will be injected into the water stream to control the $\mathrm{pH}$ from 7.6 to 7.8 and to prevent biofouling of the heat exchange surfaces. The treated water will be discharged into the deluge storage tank.

An open 8,000-gallon tank will store a 30-minute supply of delugeate water. The tank will be provided with an overflow and drains that discharge to the plant waste water pond. Deluge water will not be used during the colder season and the tank will be drained.

\section{RINSE SYSTEM}

The rinse pump will be identical to the deluge pump. It will take treated water from the rinse water storage tank and deliver it to the rinse water distribution system.

The rinse pump will discharge into a common header supplying the heat exchanger delta assemblies. The deluge distribution pipe from each delta assembly will be connected to the rinse water distribution header through an electrically operated valve. The excess rinse water draining from the bottom of the heat exchangers will be combined with the delugeate and discharged to the delugeate storage tank.

A11 piping in the rinse system will be CPVC, class 125.

The water source for the rinse system will be the same as for the deluge system. A sodium zeolite water softener in the water treatment building will produce 1,000 gph of water containing less than $5 \mathrm{ppm}$ calcium as $\mathrm{CaCO}_{3}$. This water will be discharged into the rinse water storage tank. 
The rinse water storage tank will be a coated steel or nonmetallic closed-top tank of 4,000 gallon capacity. This tank will be vented to the atmosphere. Drain and overflow lines will discharge to the plant waste water pond.

\section{AMMONIA LOOP EVACUATION AND PURGE SYSTEM}

Taps will be provided at points in the ammonia vapor system and the cooling tower hot well for removal of gaseous impurities from the system. These vents will be located near the nominal liquid ammonia surface. These vents will be small diameter ( $3 / 4$ in. to 1 in.) and will have normally closed solenoid valves manually controlled from the operating room. Locations requiring venting will be 1) the separator drum, 2) the cooling tower vapor headers, and 3) the ammonia hot well. All valves will discharge into a common line terminating at the waste aqueous ammonia storage tank. A check valve will prevent return of aqueous ammonia into the system.

All components will be carbon steel. Lines may be routed as is convenient.

A 8,000-gallon waste aqueous ammonia storage tank will be located near the ammonia storage facility. This tank will be constructed from carbon steel and vented to the atmosphere. A line from the water treatment facility building will fill this tank with raw water. Vapor from the evacuation and purge systems and the discharge of the vacuum pump will be introduced into the water by a sparger line located at the bottom of the tank. This line will run across the diameter of the tank and will have numerous holes for bubbling the vapors through the water. The tank will be arranged to facilitate loading the aqueous solution into tank trucks for sale or disposal. Electric heaters will prevent freezing of the tank contents.

A vacuum pump will evacuate the air from the system prior to filling with ammonia. This pump will be located on the cooling tower foundation slab and will be capable of evacuating the ammonia system to $26 \mathrm{in}$. $\mathrm{Hg}$ pressure in 24 hours or less. The vacuum pump will be connected to the vent system and discharge to the aqueous ammonia storage tank's sparger line. 
The vacuum pump will have the capability of discharging against the water head in the aqueous ammonia tank. The motor shall be rated for a Class I, Division 2 location.

AMMONIA VENT SYSTEM

Pressure relief valves will be provided to prevent the ammonia heat transport system, piping, and vessels from potential rupture. Valves will be sized and rated in accordance with ASME Piping and Pressure Vessel Codes. Valves will be provided for the 1) ammonia storage tanks, 2) vapor separator, and 3) ammonia hot well.

The pressure relief valves will vent to a common line that will be connected to the waste aqueous ammonia storage tank. Check valves will prevent return of waste aqueous ammonia into the system.

A11 components will be carbon steel. Lines may be routed as convenient.

\section{AMMONIA STORAGE SYSTEM}

A 12,000-gallon storage vessel will be provided at the location specified in Section 4. This vessel will be constructed from carbon steel and will be rated for 250 psi at $100^{\circ} \mathrm{F}$. This vessel will be provided with level gages and will discharge into a common header through a valve. Equipment and facilities required to transfer anhydrous ammonia to the vessel from tank trucks or rail tank cars will be provided.

The storage vessel will be provided with pressure relief valves, vented to the waste aqueous ammonia storage tanks. A sun shade and water spray cooler system will further protect the storage vessel during periods when the outside ambient temperature may exceed $100^{\circ} \mathrm{F}$.

A system fill pump will provide ammonia to the ammonia phase-change heat transport loop. This pump will have the capability to fill the system

- from the ammonia storage tanks, and will be located in a pit to provide required NPSH. This pump will be rated for $350 \mathrm{psi}$ at $150^{\circ} \mathrm{F}$. 
The fill pump will have a valve and control arrangement to provide for either filling or draining the heat transport loop, in order to maintain the required inventory of ammonia. The valves will be air operated and will be manually controlled from the plant control room.

In the event that maintenance work must be performed on the ammonia heat transport loop, or a minor leak should occur, the system will have the capability to pump the majority of condensate ammonia back to the storage tanks. This will be accomplished by an arrangement of system pumps, auxiliary drain pumps, piping, valves, and controls. The major portion of liquid ammonia will reside in the vapor separator, condenser/reboiler loops, the condensate return piping, and the heat exchanger hot well. The pump out of liquid ammonia from the heat transport loop will be manually controlled to prevent release of the storage tank relief valves. All piping will be made from carbon steel and designed to maintain liquid velocities at $17 \mathrm{fps}$ or less.

\section{AIR SUPPLY}

Instrument air for use in the controllers specified for the condenser/ reboiler structure will be obtained at some convenient location on Grade $386 \mathrm{ft}$ from the plant instrument air system.

All instrument air lines will be 1/4-in. OD and larger. Each instrument will have a shutoff valve to isolate it for removal or maintenance. All lines subject to freezing of moisture will be trace-heated and insulated. 


\section{ELECTRICAL DESCRIPTION}

\section{ELECTRICAL SUPPLY REQUIREMENTS}

Three-phase power at $440 \mathrm{~V}$ will be provided for components listed in Table 5. Table 5 also provides the estimated maximum demand for each component. The source of this power will be the plant load center located on Grade $386 \mathrm{ft}$. The motor feeder overcurrent protection device will be placed in existing spare cubicle space in the load center. This feeder will supply the motor control center to be described in this section.

TABLE 5. Three-Phase, $440 \mathrm{~V}$, Power Requirements

\begin{tabular}{lr}
\multicolumn{1}{c}{ Component } & $\begin{array}{r}\text { Estimated } \\
\text { Demand }\end{array}$ \\
\cline { 2 - 2 } Condensate Return Pump & 20 \\
Mechanical Deaerator & 2 \\
Reboiler Recirculating Pump & 10 \\
Ammonia Condensate Return Pump & 10 \\
Cooling Tower Fans & 120 \\
Deluge Pump & 10 \\
Rinse Pump & 10 \\
Drain/Fil1 Pump & 25 \\
Vacuum Pump & 5 \\
Condensate Return Pump Pit & 5
\end{tabular}

Single-phase $110 / 220 \mathrm{~V}$ power will be provided for instrumentation lighting and utility purposes. Four receptacles will be provided in the reboiler structure, four in the water treatment building and six at the base of the cooling tower. All receptacles will be $15 \mathrm{amp}$ and $110 \mathrm{~V}$. A11 outdoor receptacles will have ground fault protection. Approximately $4 \mathrm{~kW}$, 
$220 \mathrm{~V}$ power will be provided to the water treatment building for space heating and miscellaneous purposes. This single-phase power will be derived from a step-down transformer located at the facility's motor control center.

Power for the control panel is estimated to be less than $2 \mathrm{~kW}$ and will be obtained from existing sources of supply in the control room.

\section{MOTOR CONTROL CENTER AND WIRING}

All facility wiring, electrical equipment, and motors located outside the main walls of the power plant will be in compliance with the national electrical code requirements for a Class I, Division 2 hazardous location.

A facility motor control center, located in the condenser/reboiler structure, will contain the required motor disconnecting means, motor branch circuit overcurrent protection, motor controller and motor running overcurrent protection for all motors listed in Table 5. Additional space will be provided for serving an additional four unspecified motor circuits with a combined rating of $50 \mathrm{hp}$.

\section{$\underline{\text { LIGHTING }}$}

Incandescent light fixtures designed for Class I, Division 2 locations will be supplied in the condenser/reboiler structure to attain a uniform lighting level of $3 \mathrm{ft}-\mathrm{c}$ at floor level. Fluorescent fixtures in the water treatment building will provide $10 \mathrm{ft}-\mathrm{c}$ at table height. Elevated light fixtures will be provided on four sides of the cooling tower to obtain an overall lighting level of $5 \mathrm{ft}-\mathrm{c}$ at ground level. 


\section{INSTRUMENTATION AND CONTROLS}

\section{AUTOMATIC CONTROLS}

The cooling tower heat dissipation rate is controlled to maintain the ammonia vapor pressure below the system design point. Automatic controls are specified in Table 6. At ambient temperatures below the system design value the ammonia vapor pressure will normally be below the design point. However, on a hot day the ammonia pressure may rise above the design point. Under these circumstances the heat exchange deluge control (Item 5) would sequentialiy turn on a deluge water to each heat exchanger section as the pressure rises in increments above the design point. When the pressure falls, the pressure switches will shut down the deluge to the heat exchanger section as the "off" set pressure for that section is obtained. When the deluge for a section is stopped, an annunciator in the control room notifies the operator for need of rinsing, which is controlled manually.

The cooling tower fans will be provided with automatic controls to start them whenever system pressure rises above an adjustable set point. The fans will remain on until manually shut down. The manual shutdown control shall be suitably guarded to prevent accidental fan shutdown when the facility is operating.

Items 4 and 5 pressure switches will have individually adjustable "on" and "off" set points. These set points will be adjustable from the control room. Override switches will enable manual control of the deluge system operation.

\section{MANUAL CONTROLS}

Table 7 lists the manual controls to be provided. These controls will be located on a new panelboard to be placed in the plant control room. The panelboard will also contain the process instrumentation and annunciators. The panelboard will be placed where convenient for monitoring and control by regular plant operating personnel. 


\section{TABLE 6. Automatic Controls}

\begin{tabular}{|c|c|c|c|c|c|c|c|c|}
\hline & $\begin{array}{c}\text { Variable } \\
\text { Controlled }\end{array}$ & $\begin{array}{l}\text { Type } \\
\text { Control } \\
\end{array}$ & $\begin{array}{c}\text { Sensor/ } \\
\text { Transmitter } \\
\end{array}$ & Range & $\begin{array}{l}\text { Controlling } \\
\text { Element }\end{array}$ & $\begin{array}{l}\text { Controller } \\
\text { Location }\end{array}$ & $\begin{array}{r}\text { Control } \\
\text { Accuracy }\end{array}$ & Comnents \\
\hline 1) & Hot Well Level & Pneumatic & $\begin{array}{l}\Delta^{P} \text {-Pneumatic } \\
\text { Signal }\end{array}$ & As Required & $\begin{array}{l}\text { V-l Valve/3 Way/ } \\
\text { Air Operator }\end{array}$ & $\begin{array}{l}\text { Condensor } \\
\text { Vicinity }\end{array}$ & TBD & \\
\hline 2) & $\mathrm{NH}_{3}$ Hot Well Level & Elect/Pneumatic & $\begin{array}{l}\therefore \text { P-Transducer } \\
\text { AP-Air Signal }\end{array}$ & As Required & $\begin{array}{l}\text { V-2 Valve/3 Way/ } \\
\text { Motor Operator }\end{array}$ & $\begin{array}{l}\text { Test Tower } \\
\text { Vicinity }\end{array}$ & $T B D$ & \\
\hline 3) & $\begin{array}{l}\text { Reboiler/Separator } \\
\text { Drum Leve? }\end{array}$ & Pneumatic & $\begin{array}{l}\text { AP-Pneumatic } \\
\text { Signal }\end{array}$ & As Required & $\begin{array}{l}\text { V-3 Valve/Air } \\
\text { Operator }\end{array}$ & $\begin{array}{l}\text { Condensor } \\
\text { Vicinity }\end{array}$ & $T B D$ & \\
\hline 4) & Tower Fan Control & On/Off Set Points & $\begin{array}{l}\mathrm{P}_{\mathrm{NH}_{3}} / \mathrm{P}_{\text {air }} \\
\text { o Reboiler Drum }\end{array}$ & $150-250$ ps $i$ & $\begin{array}{l}\text { Fan Motor } \\
\text { Operator Relay }\end{array}$ & Control Room & $+2 \mathrm{psi}$ & $\begin{array}{l}\text { Manual Shutdown Only } \\
\text { When System Pressure } \\
\text { Is Below "0ff" } \\
\text { Setpoint }\end{array}$ \\
\hline 5) & $\begin{array}{l}\text { Heat Exchanger } \\
\text { Deluge }\end{array}$ & On/0ff Set Points & $\begin{array}{l}\mathrm{P}_{\mathrm{NH}_{3}} /{ }^{\mathrm{P}} \text { air } \\
\text { a Reboiler Drum }\end{array}$ & $300-400$ ps i & $\begin{array}{l}\text { Deluge Punp } \\
\text { Operator Relay \& } \\
\text { Electricor Air } \\
\text { Deluge Valve } \\
\text { Operator } \forall-4 n\end{array}$ & Control Roon & +2 psi & $\begin{array}{l}\text { One Control for Each } \\
\text { Heat Exchanger: Pump } \\
\text { Switched on when } \\
\text { First Valve is } \\
\text { Activated }\end{array}$ \\
\hline 6) & $\begin{array}{l}\text { Deluge Storage } \\
\text { Tank Level }\end{array}$ & Pneurlatic & $\begin{array}{l}\text { P-Pneumat ic } \\
\text { signal }\end{array}$ & As Required & V-6/Air Operator & At Tank & $T B D$ & \\
\hline 7) & $\begin{array}{l}\text { Vapor Flow } \\
\text { To Augmentation } \\
\text { Condenser }\end{array}$ & Pneuniatic & $\begin{array}{l}\text { P-Pneumatic } \\
\text { Signal }\end{array}$ & $150-350$ ps $i$ & V-7 Air Operator & Control Room & $T B D$ & $\begin{array}{l}\text { Vapor Flow Regulated } \\
\text { to Hoid System } \\
\text { Pressure Constant }\end{array}$ \\
\hline
\end{tabular}




\section{TABLE 7. Manual Control Specifications}

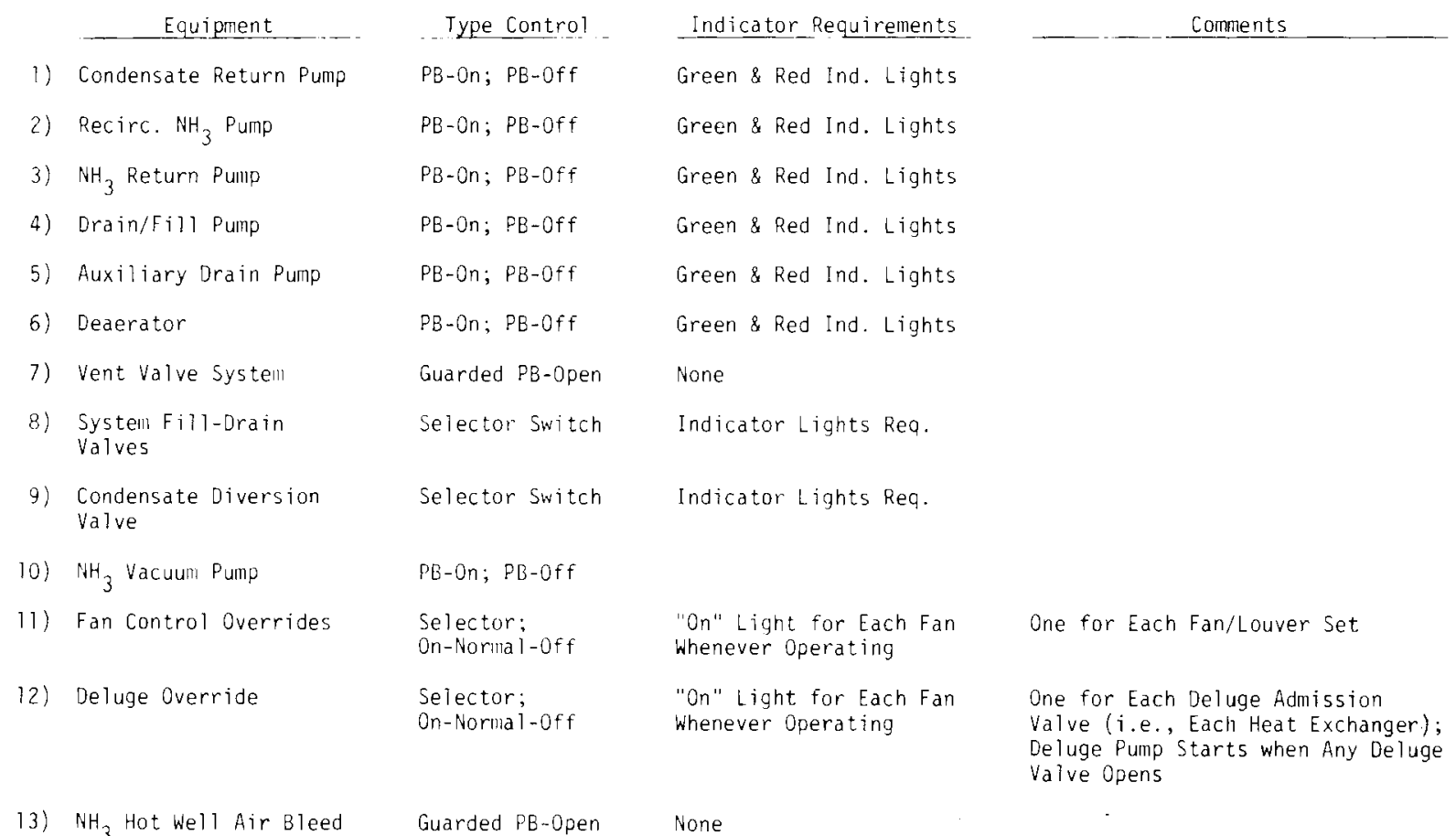

\section{PROCESS INSTRUMENTATION}

Process instrumentation specified in Table 8 will be provided. Readouts indicated for location in the control room will be located on the manual control panelboard. All readouts on the panelboard will be sufficiently large to enable monitoring from a distance of $10 \mathrm{ft}$ by a person with normal visual acuity.

\section{AMMONIA VAPOR DETECTION}

Suitable ammonia vapor detectors will be provided in the reboiler area, cooling tower area, inside the cooling tower, tank truck off-loading area and the $\mathrm{NH}_{3}$ hot well pit. The type and sensitivity of these detectors will be determined later. They will be capable of sounding a local alarm and activating an annunciator and alarm on the facility control board. 
TABLE 8. Process Instrumentation

1) Reboiler Hot Well Level
2) Tower $\mathrm{NH}_{3}$ Hot Well Level
3) Deluge Water Tank
4) Turbine Exhaust Pressure
5) Ammonia Vapor Pressure
6) $\mathrm{NH}_{3}$ Recirc, Pump
Differential Pressure
7) $\mathrm{NH}_{3}$ Return Pump
Pressure Differential
8) Deluge Pump Discharge
Pressure
9) Rinse Pump Discharge
Pressure
10) NH Storage Pressure
11) Hot Well Pump Discharge
Pressure
12) Fill Pump Discharge
Pressure
13) Ambient Temperature

14) W.B. Temperature

15) $\mathrm{NH}_{3}$ Hot We1] Temperature
16) Condensate pH
17) $\mathrm{NH}_{3}$ Storage Tank
18) Aqueous Ammonia Tank
19) Rinse Tank
20) Blowdown Flow
21) Augumentation Condenser Shell Side Pressure

\begin{tabular}{|c|c|c|c|c|}
\hline Sensor/Transmitter & Readout Type & Accuracy & $\begin{array}{l}\text { Readout } \\
\text { Location }\end{array}$ & Range \\
\hline$\Delta \mathrm{P} /$ Pneumatic & Analog Display & $\pm 5 \%$ F.S. & $C R$ & As Required \\
\hline$\triangle P / P$ neumatic & Analog Display & $"$ & $C R$ & As Required \\
\hline$\Lambda P / P$ neumat ic & $\begin{array}{l}\text { Analog/Strip Chart } \\
\text { Recorder }\end{array}$ & $"$ & $C R$ & As Required \\
\hline P-Pressure Signal & Analog Display & $"$ & $C R$ & $0-30 \mathrm{~mm} \mathrm{Hg}$ \\
\hline P-Pressure Signal & Analog/Strip Chart & $"$ & $C R$ & $0-500$ psi \\
\hline$\triangle$ P-Pressure Signal & Analog Display & $"$ & CR & $0-30$ psi \\
\hline$\triangle \mathrm{P}-$ Pressure Signa 1 & Analog Display & $"$ & $C R$ & $0-30$ psi \\
\hline P-Pressure Signal & Analog Display & $"$ & $C R$ & $T B D$ \\
\hline P-Pressure Signal & Analog Display & $"$ & $C R$ & $T B D$ \\
\hline Bourdon Tube & Analog Display & $\pm 5 \%$ & Local & $0-500 \mathrm{psi}$ \\
\hline Bourdon Tube & Ana log & $+5 \%$ & Local & $-15-100$ psi \\
\hline Bourdon Tube & Analog & \pm 5 & Local & $-15-100 p s i$ \\
\hline$T-C$ & $\begin{array}{l}\text { Strip Chart } \\
\text { Recorder }\end{array}$ & $+5 \%$ & $C R$ & $\begin{array}{l}0-150^{\circ} \mathrm{F} \\
\text { (Three-Pen } \\
\text { Recorder) }\end{array}$ \\
\hline W. B. Element $T-C$ & $\begin{array}{l}\text { Strip Chart } \\
\text { Recorder }\end{array}$ & $\pm 5 \%$ & $C R$ & $\begin{array}{l}0-100^{\circ} \mathrm{F} \\
\text { (Three-Pen } \\
\text { Recorder) }\end{array}$ \\
\hline$T-C$ & $\begin{array}{l}\text { Strip Chart } \\
\text { Recorder }\end{array}$ & $\pm 5 \%$ & $C R$ & $\begin{array}{l}0-150^{\circ} \mathrm{F} \\
\text { (Three-pen } \\
\text { Recorder) }\end{array}$ \\
\hline $\mathrm{pH}$ Cell & Analog Display & $+10 \%$ & $C R$ & $0-18$ \\
\hline Float & Analog & $\pm 5 \%$ & Local & As Required \\
\hline Float & Analog & $+5 \%$ & Local & As Required \\
\hline Float & Analog & $5 \%$ & Local & As Required \\
\hline Rotameter & Ana log & $5 \%$ & Local & $0-100 \mathrm{gpm}$ \\
\hline $00 /$ Pneumatic & Analog & $5 \%$ & $C R$ & $0-500$ psi \\
\hline
\end{tabular}


ANNUNCIATORS AND ALARMS

Annunciators with alarms will be provided for the items listed in Table 9. The annunciator panel will be placed on the manual control panelboard at such an elevation to assure visibility from the main operating area of the control room. The alarm sound will be distinctively different from other alarms for existing equipment.

TABLE 9. Annunciator and Alarm
1) High Level
2) Low Level
Hot Well
3) High Level
4) Low Leve1
Reboiler Drum
5) High Level
6) Low Leve1
$\mathrm{NH}_{3}$ Hot Wel 1
7) High Level
8) Low Level
Delugeate Tank
9) High Level
10) Low Leve1
Rinse Tank
11) High Pressure

12) Low Pressure

13) High Turbine Back Pressure

14) Heat Exchanger Section Wash

(One for each Section: Goes

15) Heat Exchanger Section Wash on when deluge to that section

16) Heat Exchanger Section Wash is turned off automatically or

17) Heat Exchanger Section Wash manually - manual annunciator reset)

18) Condensate High $\mathrm{pH}$

19) High $\mathrm{NH}_{3}$ Vapor Concentration - Reboiler Area

"

"

II

- Cooling Tower Area

\section{1}

"

II
- Inside Cooling Tower

- Tank Truck Off-Loading Area

- $\quad \mathrm{NH}_{3}$ Hot Well Pit 


\section{TEST INSTRUMENTATION}

The sensors specified in Table 10 will be provided to measure the indicated variables. All signal lines will be brought to the location at Grade $386 \mathrm{ft}$ of the plant where the signal conditioning equipment and data acquisition system (DAS) will be located. The signal lines will terminate in a junction box having 150 line-pair termination capacity. Signal conditioning equipment will be provided for each sensor as required. The DAS will be capable of 100 millisecond sampling rate and will contain an integral time base recording capability (month, day, hr, min, sec) to facilitate synchronizing and correlating events. The DAS will be capable of automatic scan initiation at intervals ranging from "continuous" to 24 $\mathrm{hr}$. The signal conditioning system and DAS will have $100 \%$ reserve capacity to handle additional flow, pressure, temperature and power consumption data as specified in Table 10. 


\section{TABLE 10. Test Instrumentation}

\begin{tabular}{|c|c|c|c|c|c|}
\hline$\ldots$ & Variable & Sensor - & Ranye. & Accuracy & Comments . . . \\
\hline 1) & Turbine KW & Hall Effect Xducer & $0-10 \mathrm{~min}$ & 2 & \\
\hline 2) & Tower Fan Power & Hall Effect iducer & $\left.T B^{\prime \prime}\right]$ & 2 & \\
\hline 3) & $\begin{array}{l}\text { Test System Total } \\
\text { Power Consumption }\end{array}$ & knh Meter & Standara & 2 & Read-out locally; not on whis \\
\hline 4) & Recirc. Puinp kw & Hall fffect kducer & $0-2.2 \mathrm{kH}$ & 2 & \\
\hline 5) & Exhdust Pressure & $y$-xducer & $0-30$ in. $\mathrm{Hg}$ & j). & \\
\hline 6$)$ & $\mathrm{HH}_{3}$ Vapor Pressure & & $3-54 i)$ psi & 0.5 & \\
\hline 7) & $\begin{array}{l}\text { Tower } \mathrm{NH}_{3} \text { Vapor } \\
\text { Distribution Header }\end{array}$ & & $0-500$ p5i & 0.5 & \\
\hline B) & Tower $\mathrm{NH}_{3}$ Hot Hell & & $2-500$ psi & 0.5 & \\
\hline 9) & $\mathrm{NH}_{3}$ Return Pressure & " & j-500 psi & 0.5 & \\
\hline 10) & $\begin{array}{l}\text { Ht. Ex. Jistribution } \\
\text { Header Pressure }\end{array}$ & P-rducers & -80 & 3.5 & Jne fur each neat exchanger \\
\hline 11) & Hot well Temperature & $\because$ & $50 \cdot 25 \mathrm{~F} \mathrm{~F}$ & $+1 F$ & \\
\hline 12) & Nit $3^{\text {Hot }}$ well Temperd ture & & & $+2 F$ & \\
\hline 13) & $i_{H} H_{3}$ Return Temperature & & & $+2 F$ & \\
\hline 14) & Delugate Temperature & & $50-i 50 \mathrm{~F}$ & $.1 \mathrm{~F}$ & \\
\hline 15) & Ueluge Retur" Temperature & & & & \\
\hline 16) & Anbient Temperature & & & & \\
\hline 17) & Anblent $T, O, B$. & $\therefore-J P C e l 1$ & & & \\
\hline 18) & Air Discharge Terliperature & $i$ & & & For eachion outlet \\
\hline 19) & Air Discharge U.B. & $\because$ & & & For edch fon outlet \\
\hline 20) & rt. Ex. Uutlot Telperature & $i$ & $=-25:$ & $\because: F$ & For edch neat excranger \\
\hline 21) & $\begin{array}{l}\mathrm{iH}_{3} \text { Condensote } \\
\text { Temperature }\end{array}$ & $\because$ & $2-60 \%$ & $\therefore s$ & \\
\hline 22) & Condensate Flowrate & iurbinu r. & 2200 & $\therefore$ & $\cdot$ \\
\hline 23) & Reboiler Liquid Return & & 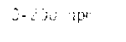 & & \\
\hline 24) & Condensate $\mathrm{NH}_{3}$ Return & & $\therefore-750$ 15 & & \\
\hline 25) & $\begin{array}{l}\text { rt. Ex. Condensate } \\
\text { Return Flow }\end{array}$ & & $\because$ & & $\begin{array}{l}\text { trree selected heat } \\
\text { exchangers instrumented }\end{array}$ \\
\hline 26) & $\begin{array}{l}\text { ihy Condensate } \\
\text { Collection Lille }\end{array}$ & & $-52 y 04:$ & & \\
\hline 27) & Total Deluge Application & & -32 & & \\
\hline (3) & Leluge Return Flow & & - w is & $\therefore$ & \\
\hline (9) & Fan-On Indicator & Relaj & 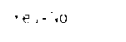 & 10 & Une for each $f_{d n}$ \\
\hline 30) & $\begin{array}{l}\text { He: Ex. veluge } \\
\text { Valve Dpen }\end{array}$ & Rela; & & & Une for each ralue \\
\hline 31) & Vent Systen Open & $\operatorname{Rela} y$ & & & \\
\hline 32: & Wiversion Valve Open & $\operatorname{Rel} d y$ & & & \\
\hline 33 & Drdin Fil: Pumbin on & Relay & & & \\
\hline 34 & Rinse Pumb in & $R_{0}{ }^{4}$ & & & \\
\hline 3b) & $\begin{array}{l}\mathrm{NH}_{3} \text { Hot meli } \mathrm{Arr} \\
\text { Bleed on }\end{array}$ & $\mathrm{H}: \mathrm{d}$ & & & \\
\hline 36) & Iime \& Date & Clock & & & Integral part of DAS \\
\hline $\begin{array}{l}37) \\
38 !\end{array}$ & Blade Pitch & P-xducer & $0.1505 i$ & 2 & $\begin{array}{l}\text { Measures tiade pitch } \\
\text { Signal Pressure }\end{array}$ \\
\hline 39$)$ & Unassigned Teliperatures & & & & \\
\hline 45) & & & & & \\
\hline 46) & & & & & \\
\hline & Unassigned Pressures & & & & \\
\hline 50) & & & & & \\
\hline $51 !$ & & & & & \\
\hline & Unassigned Flows & & & & \\
\hline 70 & & & & & \\
\hline 711 & & & & & \\
\hline & 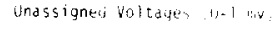 & & & & \\
\hline
\end{tabular}




\section{DECOMMISSIONING REQUIREMENTS}

The Dry Cooling Tower Demonstration Facility will be decommissioned at the end of the programmed operational tests to the extent necessary to place the No. 1 house unit in its original operating state, and to remove the test facility from PG\&E's plant.

\section{EXHAUST STEAM DUCT}

The connection to the turbine exhaust duct will be blanked off and the exhaust steam diversion piping will be removed from within the plant building. The penetration through the plant wall will be repaired.

\section{CONDENSER/REBOILER}

The condenser/reboiler, separator, and related piping, pumps and controls will be removed from the concrete pad. The support structure and weather protection will also be dismantled. The concrete pád will be left in place.

\section{COOLING TOWER}

The facility cooling tower will be disassembled and removed from the plant site. Equipment removed will include all associated pumps, piping and controls. Concrete footings will be left in place.

\section{AMMONIA HEAT TRANSPORT SYSTEM}

All ammonia transport piping will be dismantled and removed from the plant site. Removed piping will include the condensate, vapor export, return, drain/fill, purge and vent lines.

\section{AMMONIA STORAGE}

The ammonia storage vessels and drain/fill pump will be dismantled and removed from the plant site. Concrete supports for tanks will be left in place. The waste aqueous ammonia storage tank will be removed from the plant site. 


\section{DELUGE AND RINSE SYSTEM}

The water treatment equipment, storage tanks and related pumps and piping will be dismantled and removed from the plant site. The water treatment building will be left in place.

\section{ROADS AND WALKWAYS}

A11 disturbed roads, walkways and parking lots damaged during decommissioning will be restored to original condition.

\section{ELECTRICAL}

All utility and lighting electrical wiring, conduit, fixtures and panels will be removed back to the plant load center.

\section{INSTRUMENTATION AND CONTROLS}

A11 controls and instrumentation installed for the test. facility, including the control panelboard, process instrumentation, annunciators, alarms, and data acquisition system, will be removed.

\section{FINAL DISPOSITION}

A Memorandum of Understanding will be developed between EPRI, PG\&E and BNW to outline the procedures and final disposition of the components and materials. 


\section{OCCUPATIONAL AND ENVIRONMENTAL SAFETY}

\section{ENVIRONMENTAL ASSESSMENT}

Appendix E provides a preliminary assessment of the environmental impact. This assessment was prepared to assure compliance with applicable State and Federal environmental regulations. Should this facility be constructed as programmed, design would incorporate features to ensure that environmental impacts are within acceptable limits.

\section{OCCUPATIONAL SAFETY}

The codes and standards identified in previous chapters will ensure adequate safety with regard to conceptual design. The design criteria will require features to provide personnel safety and to prevent fire, high wind, or earthquake loss. An Operational Safety Analysis Report (OSAR) has been prepared by PNL and evaluates maximum credible incidents and the mode for facility shutdown in the event of a failure of any individual pieces of equipment or systems. The OSAR also evaluated the impact of an incident or emergency shutdown on the existing turbine.

Routine audits will be conducted during operation to insure that procedures are not violated and safety limits are not exceeded. 


\section{QUALITY ASSURANCE PROGRAM}

To assure that the functional criteria and integrity of this project are completely satisfied, the design and construction of this test facility shall be controlled in accordance with QA/QC procedures developed by the Architect Engineer/Construction Management firm responsible for those tasks. Operation planning and operation of the facility will be controlled in accordance with procedures developed by BNW and guidelines provided by BNWL-MA-65, "Battelle Quality Assurance Manual."

Power Generating Cooling Systems (PGCS), Consulting Engineers, will assist with the design review of the demonstration facility. Mr. George L. Henderson of PGCS has reviewed the Functional Design Criteria and conceptual design. His comments are summarized in Appendix F. 


\section{ENERGY IMPACT STATEMENT}

The energy requirements for contruction of the test facility will include electricity for power tools and equipment, and fuel for vehicles. The energy requirements for operation of the test facility will be those associated with operating the PG\&E Kern Power Plant. Energy will be provided in the form of steam at a variable rate from 6,000 to $60,000 \mathrm{lb} / \mathrm{hr}$, depending on the programmed test being run, and based on 1,000 $\mathrm{hr} / \mathrm{yr}$ of operation. The estimated quantity of fuel consumed is $12,815 \mathrm{bbl}$ of 011 , or $77 \times 10^{6}$ $\mathrm{ft}^{3}$ of gas, depending on the type of fuel used. This assumes that the main unit is not operating. 
APPENDIX A

FIVE YEAR SUMMARY OF CLIMATOLOGICAL DATA BAKERSFIELD, CALIFORNIA 
A TEMPERATURE AND WIND SPEED-RELATTVE HUMIDITY OCCURRENCES:

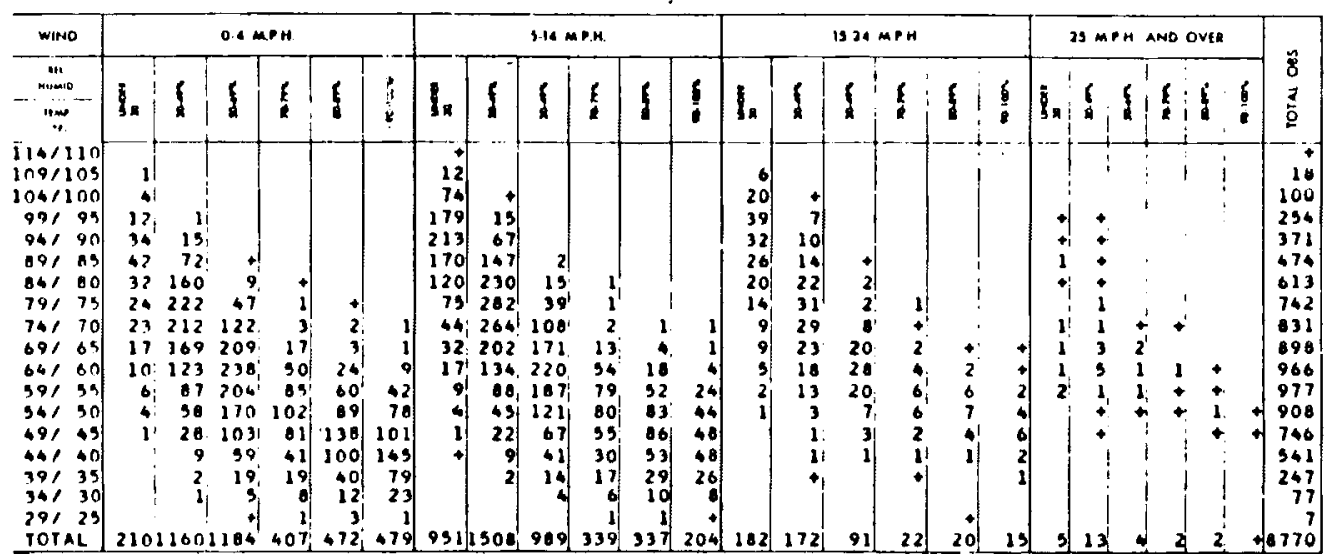

In Tubles A and C, occurrences are for the everake year (s-year total divided by 5). oxactly equal to column and rov totals. "t" indlcates more then o but lese than 0.5 .
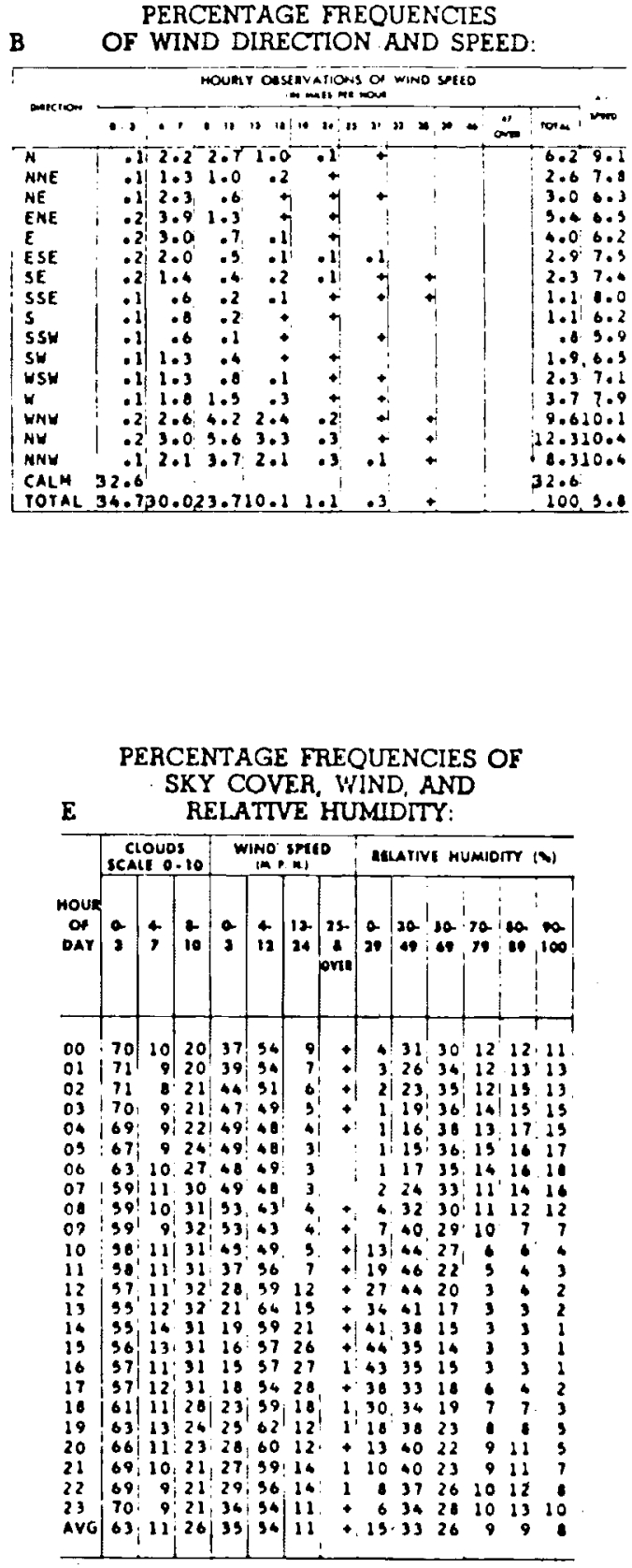


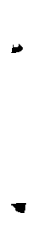


APPENDIX B

DRY COOLING TOWER DEMONSTRATION FACILITY OPERATIONS AND TESTING PROGRAM 
The objective of this appendix is to outline the structure of the "Operations and Testing Subtask" for the Kern Plant Demonstration Facility, suggest responsibilities of PNL and PG\&E, and outline specific tests anticipated for preliminary planning, scheduling and budget preparation.

\section{SUBTASK BREAKDOWN}

Table B-1 and Figure B-1 define a conventional operation and testing program that encompasses activities related to the demonstration testing program, from OATP planning and performance to final reporting and information dissemination. Included are the directly related planning and analysis required for preparation of testing specification, operation, data analysis and reporting. PG\&E will be responsible for those activities directly related to the operation and maintenance of the Kern Power Station facility; other activities will be the responsibility of PNL. Specific responsibilities will be established in a Site Use and Support Services agreement to be negotiated with PG\&E.

\section{TESTING PROGRAM}

Four types of experimental activities are delineated in the Subtask breakdown. These are:

1. OATP and component testing

2. facility performance testing

3. demonstration testing

4. nonstandard condition testing

OATP and component tests will be performed first. The other testing will be performed concurrently, or in an order to facilitate cost-effective operation.

Operational Acceptance and Component Testing activity will validate the performance of major facility components for acceptance from the vendor/constructor, and provide the detailed performance data required 
for Operational Optimization Analysis (Activity 4.2), Pretest Prediction (Activity 4.3), Facility Tuneup Planning (Activity 5.1) and Facility Tuneup (Activity 6.5). The types of tests to be performed are outlined in Table B-2. The performance of these tests requires the facility to be totally operational, though not necessarily functioning at optimum efficiency. Many of the test series included in Table B-2 may be performed simultaneously to effect an economy of time and costs.

Performance Tests will obtain data on the overal1 steady-state performance of the system adjusted in the optimum manner determined in Activities 4.2 and 5.1. These data will be used to determine the cost penalties associated with this particular installation and to extrapolate these penalties to a prototype installation using a similar cooling concept. Also, the performance test sequence will include certain tests to validate the attainment of optimum conditions and thereby aid the validation of analytic and computer methods used in activities $4.1,4.2,4.3$, and 4.5. A summary of anticipated tests is provided in Table B-3.

Demonstration Tests will determine the operability of the system under normally anticipated conditions, other than steady state. They may be performed concurrently with the Performance Tests. These operations are summarized in Table B-4. The data obtained will be used to determine the costeffectiveness of the procedures used and demonstrate their adequacy. If problems are encountered, additional activities will be defined to develop and demonstrate solutions.

Nonstandard Condition Tests will demonstrate the operability of the cooling concept under possible events which may endanger system integrity or degrade performance in a manner which may not be totally reversible. Candidate nonstandard condition tests are listed in Table B-5. Because of the nature of these tests, it is anticipated that some may be run at the conclusion of the testing program. However, it may be possible to integrate selected tests into the overall testing program. 


\section{REPORTING}

In addition to periodic and final reporting, a number of other reports will be issued to generate project visibility to the sponsors, co-participants, and industry. They will also provide a means for obtaining the necessary concurrences and approvals. These reports will be as shown below.

Activity

1.2

2.2

3.2

4.3

5.1

5.2
Report

Operating Manual

Operational Testing Procedures

Test Plans

Pretest Predictions: Expected Results

Facility Tune-Up Procedures

Test Procedures

A seminar or conference will be arranged at an intermediate stage and/or conclusion of the testing program to disseminate data and experience gained from operating the demonstration facility. Representatives from industry and government agencies will be invited to attend. 
TABLE B-1. Subtask Outline for Operations and Testing

SUBTASK 1.0 OPERATING PROCEDURES (PNL)

1.1 Formulate operating procedures

1.2 Prepare \& issue operating manual

1.3 Obtain PG\&E approval; revise as necessary

SUBTASK 2.0 ATPS \& OATPS (CM/AE \& PNL)

2.1 Formulate ATPS and OATPS

2.2 Issue OATP report

2.3 Obtain PG\&E concurrence and PNL approval

SUBTASK 3.0 TEST PLANNING (PNL)

3.1 Formulate test plans

3.2 Issue test plan document

3.3 Obtain industry comments

3.4 Obtain PG\&E concurrence and EPRI approval

SUBTASK 4.0 ANALYSIS \& OPTIMIZATION (PNL)

4.1 Form computer model of facility operation/economics

4.2 Optimization analysis

4.3 Pre-test prediction

4.4 Prepare memo report of expected results of test program

SUBTASK 5.0 TESTING PROCEDURES (PNL)

5.1 Prepare facility tune-up procedures

5.2 Prepare detailed testing procedures

5.3 Obtain PG\&E/EPRI approval

SUBTASK 6.0 FACILITY STARTUP (PG\&E \& PNL)

6.1 Operator training

6.2 Facility startup \& shakedown

6.3 Perform OATPs \& component tests

6.4 Analyze test results; memo report

6.5 System tune-up for optimum operation

SUBTASK 7.0 TESTING (PG\&E \& PNL)

7.1 Performance tests

7.2 Functional demonstration tests

7.3 Nonstandard condition tests

SUBTASK 8.0 DATA REDUCTION, ANALYSIS \& REPORTING (PNL)

8.1 Data reduction \& analys is

8.2 Prepare final reports

8.3 Industrial seminar/conference information dissemination 


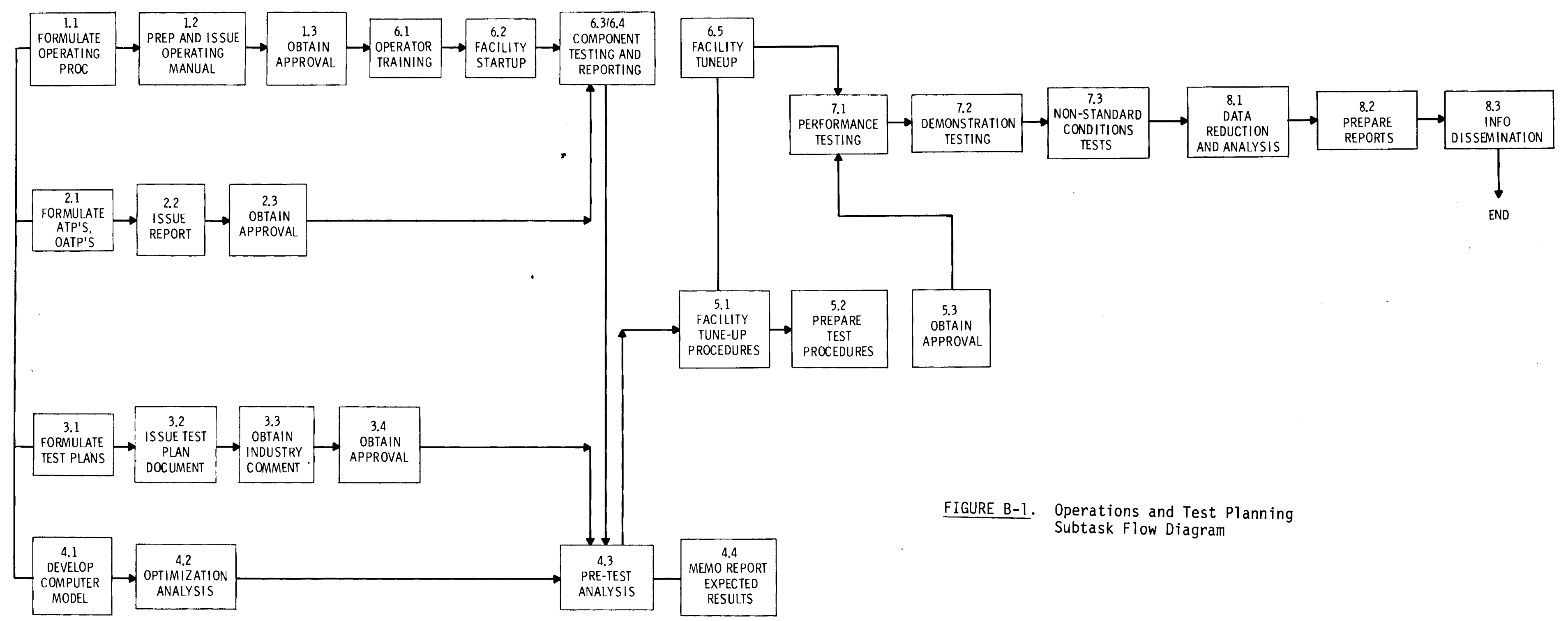


.

$-n$

-

.

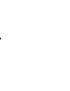

$$
\rightarrow
$$

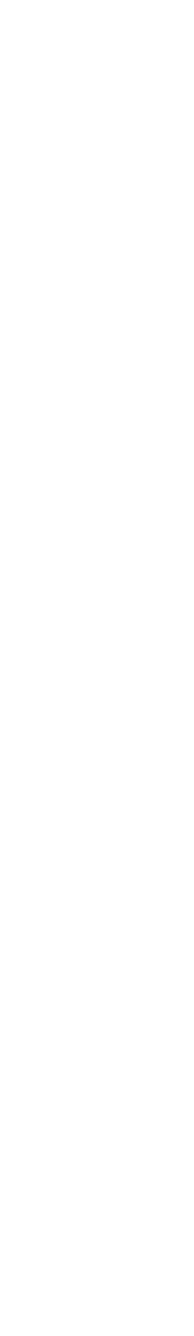




\title{
TABLE B-2. Summary of Component Testing
}

\author{
SUBTASK OBJECTIVE: To validate the performance of major components for final \\ acceptance, use in facility tune-up calculations, and \\ facility preperformance test predictions
}

Test
Series

Series

6.3 .1

Condenser/reboiler

6.3.2 Tower fans

6.3.3 Deluge pump/system

6.3.4 Rinse pump/system

6.3.5 Rinse treatment plant

6.3.6 Condensate return pump

6.3.7 $\quad \mathrm{NH}_{3}$ return pump

6.3.8 Drain/fill pump

6.3.9 Reboiler hot well level

6.3.10 Separator level controls

6.3.11 $\mathrm{NH}_{3}$ hot-well controller

6.3.12 Tower

Scope of Tests

Performance curve

Performance \& power consumption check

Test system capacity \& punip power consumption

Test system capacity \& pump power consumption

Maximum capacity; water analysis

Performance \& power consumption check

Performance \& power consumption check

Performance \& power consumption check

Function verification

Function verification

Function verification

Performance tests
Number

Tests

15

Box-Behnken test design for 4 independent variables $\left(\mathrm{P}_{\mathrm{NH}_{3}}, \mathrm{PH}_{2} \mathrm{O}\right.$, and recirculation flow of $\mathrm{NH}_{3} \& \mathrm{H}_{2} \mathrm{O}$ )

6 Check each fan at operating point with 1, 2, \& 3 fans

$4 \quad$ Check system ability to supply specified flow to heat exchangers with $1,2,3, \& 4$ operating

$4 \quad$ Check system ability to supply specified flow heat exchangers with $1,2,3, \& 4$ operating

1

3

Check shutoff \& two points on operating curve

3 Check shutoff \& two points on operating curve

3 Check shutoff \& two points on operating curve

5 Control accuracy at 4 levels; response to 25\% step change in control point

5 Control accuracy at 4 levels; response to $25 \%$ step change in control point

5 Control accuracy at 4 levels; response to $25 \%$ step changes in control point

27
Box-Behnken test design for 4 independent variables (IDT, airflow, nDELUGE, TWB) (not all 
TABLE B-3. Summary of System Performance Testing Subtask

Test

Series

7.1.1 Performance tests at optimum settings

7.1 .2

Performance tests at off-optimum settings as influenced by ambient conditions
Number of Tests/

Operating Time

Per Test

$18 / 2 \min$

Full factorial test design for 3 independent variables ( $\left.T_{D B}, \Phi, K W\right), T_{D B}$ at three levels equivalent to maximum, minimum and levels equivalent to maxim, at two levels corresponding to early morning and late corresponding to early morning and late three levels corresponding to maximum, low three levels corresponding to maximum, low output.

$<58 / 1 \min$

Repeat Test Series 7.1.1 with 1 more/less fan than optimum, 1 more/less deluge section than optimum and combinations (al) conditions may not be accessible) 
TABLE B-4. Summary of Functional Demonstration Testing Schedule

\begin{tabular}{lll}
$\begin{array}{c}\text { Test } \\
\text { Series }\end{array}$ & & \multicolumn{1}{c}{ Type of Demonstration Test } \\
7.2 .1 & & $\begin{array}{l}\text { Normal air evacuation \& NH} \\
\text { charging }\end{array}$ \\
7.2 .2 & & Normal startup \\
7.2 .3 & Normal shutdown \\
7.2 .4 & Deluge system startup \\
7.2 .5 & Wet:dry: rinse sequence \\
7.2 .6 & Fast $\mathrm{NH}_{3}$ pumpdown \\
7.2 .7 & Loss-of-load \\
7.2 .8 & Load following
\end{tabular}

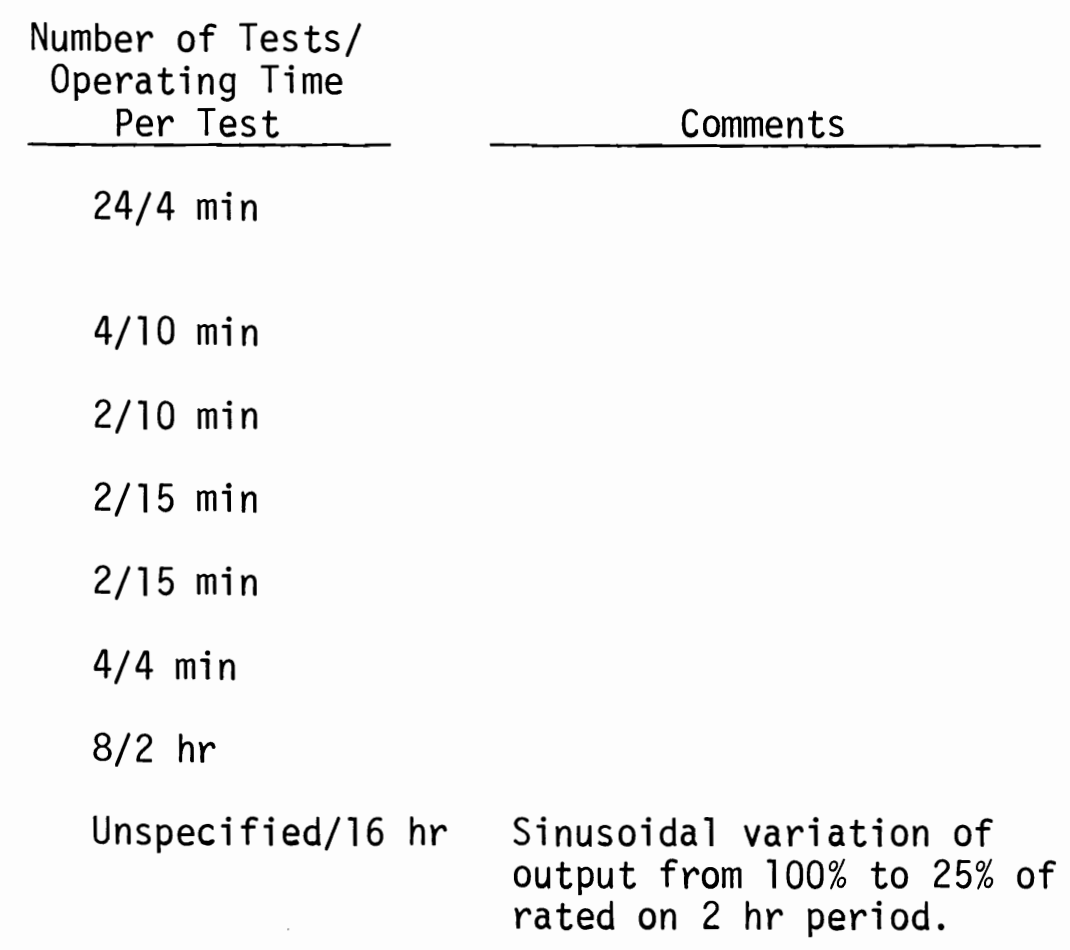


TABLE B-5. Summary of Nonstandard Conditions Testing Subtask

\begin{tabular}{ll}
$\begin{array}{c}\text { Test } \\
\text { Series }\end{array}$ & \multicolumn{1}{c}{ Scope of Test } \\
7.3 .1 & $\begin{array}{l}\text { Tower plugging: dry operation } \\
\text { (performance degradation and } \\
\text { washdown testing) }\end{array}$ \\
7.3 .2 & $\begin{array}{l}\text { Tower plugging: wet operation } \\
\text { (performance degradation and } \\
\text { washdown testing) }\end{array}$ \\
7.3 .3 & $\begin{array}{l}\text { Loss of ammonia test (performance } \\
\text { with deficient } \mathrm{NH}_{3} \text { charge) }\end{array}$ \\
7.3 .4 & $\begin{array}{l}\text { Loss of fan power (emergency } \\
\text { shutdown test) }\end{array}$ \\
7.3 .5 & Loss of $\mathrm{NH}_{3}$ recirculation pump \\
7.3 .6 & Loss of $\mathrm{NH}_{3}$ return pump
\end{tabular}

\begin{tabular}{|c|c|}
\hline $\begin{array}{l}\text { Number of Tests/ } \\
\text { Operating Time } \\
\text { Per Test, hr } \\
\end{array}$ & Comments/Bases \\
\hline $2 / 8$ & $\begin{array}{l}\text { Simulation by introduction of cotton lint } \\
\text { into airstream; washdown with delugeate and } \\
\text { other unspecified means }\end{array}$ \\
\hline $2 / 8$ & $\begin{array}{l}\text { Simulation by introduction of diatomaceous } \\
\text { earth or bentonite clay }\end{array}$ \\
\hline $1 / 4$ & $\begin{array}{l}\text { Surging operation expected (may be omitted } \\
\text { due to possibility of damage to facility } \\
\text { equipment) }\end{array}$ \\
\hline $1 / 4$ & $\begin{array}{l}\text { Demonstration of recovery procedures (may } \\
\text { be omitted due to possibility of turbine } \\
\text { damage) }\end{array}$ \\
\hline $1 / 4$ & Demonstration of recovery procedures \\
\hline $1 / 4$ & Demonstration of recovery procedures \\
\hline
\end{tabular}


APPENDIX C

WATER ANALYYSES

KERN POWER STATION 
Pacific Cass and Electric Company

Steam Department, San Francisco Division

Water Analysis Report.

To: ir. i. L. Hrodey

Power Plant

Source of samplo

Date of sample

Tine of sample

Your sample number

Date received

our number
Sample labeled and dated sa-folicre:-

Kern

$\because 7$ VeII

$8-3-76$

$--$

$\mathrm{K}-\mathrm{J}_{4}$

$8-9-76$

HP $-76-1347$

\begin{tabular}{|ll|}
\hline Color of water & None \\
\hline Slispended materiol & None \\
\hline $\mathrm{pH}$ & 9.0 \\
\hline
\end{tabular}

Parts per Million on Unilitered raterial

\begin{tabular}{|c|c|}
\hline Carbonate, $\mathrm{CO}_{3}$ & 7 \\
\hline Bicarbonate, $\mathrm{HCO}_{3}$ & 55 \\
\hline Sulfate, $\mathrm{SO}_{4}$ & 26 \\
\hline Chloride, Cl & 8 \\
\hline $\mathrm{Cal}=1 \mathrm{un}, \mathrm{Ca}$ & 4 \\
\hline Yíznesilan, $M_{B}$ & Iess thar 1 \\
\hline Regidual cations as sodiun, $\mathrm{Na}$ (calc.) & 38 \\
\hline S1ilca, $\mathrm{S}_{10}$ & $Y_{6}$ \\
\hline Calcium and magnegium hardness as $\mathrm{CaCO}_{3}$ & 12 \\
\hline Total solids by evaporation at $105^{\circ} \mathrm{C}$ & 109 \\
\hline Organic and rolatile at $310^{\circ} \mathrm{C}$ & 8 \\
\hline
\end{tabular}

Suspended Naterial

suspended material, ignited, opm.

Suscended silica, S10, $\mathrm{pFm}$.

insig510 by: ininter

$2 \times 0$

$T: C, 5 \pm 2 a$

Dats of report: $3-26-76$

E.⿻.𠃋. $\lambda \ll$ 
To: U. T. D. IFir.LLET

Power Plant Source of sample

Date of sample

Tine of sample

Your sample number

Date received

our number
Sample labeled and dated as folioxi:

$\mathrm{K} E \mathrm{SW}$

敞 Well

$7-1-76$

K-7

\section{$7-1-76$}

iis-76-1281

\begin{tabular}{|lc}
\hline Color of water & lione \\
\hline Suspended material & Noue \\
\hline py & 7.7
\end{tabular}

Parts per M1IIIon on Unflitered Katerial

\begin{tabular}{|c|c|}
\hline Carbonate, $\mathrm{CO}_{3}$ & c \\
\hline 31carbonate, $\mathrm{HCO}_{3}$ & 112 \\
\hline Sulfate, $\mathrm{SO}_{4}$ & 23 \\
\hline Chloride, $\mathrm{Cl}$ & \pm 0 \\
\hline Calcium, Ca & 21 \\
\hline Maznesium, Mg & 3 \\
\hline Rosidual cativiss as sodium, Na (calc.) & 30 \\
\hline $\mathrm{Sil1ca}, \mathrm{SiO}_{2}$ & 17 \\
\hline Cslcium and magnesium hardness as $\mathrm{CaCO}_{3}$ & 66 \\
\hline Total solids by evaporation at $105^{\circ} \mathrm{C}$ & 172 \\
\hline Organic and volatile at $310^{\circ} \mathrm{C}$ & 23 \\
\hline
\end{tabular}

Suspended Material

Suspended material, ignited, ppm.

Suspended sllica, $\mathrm{SLO}_{2}$, pm.

$\begin{aligned} \text { Anslysis by: } & \text { J. iorris } \\ & \text { i xc } \\ & \text { ride, File }\end{aligned}$

Date of report:

$7-12-76$

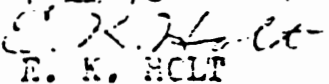


APPENDIX D

CONCEPTUAL DESIGN DRAWINGS 


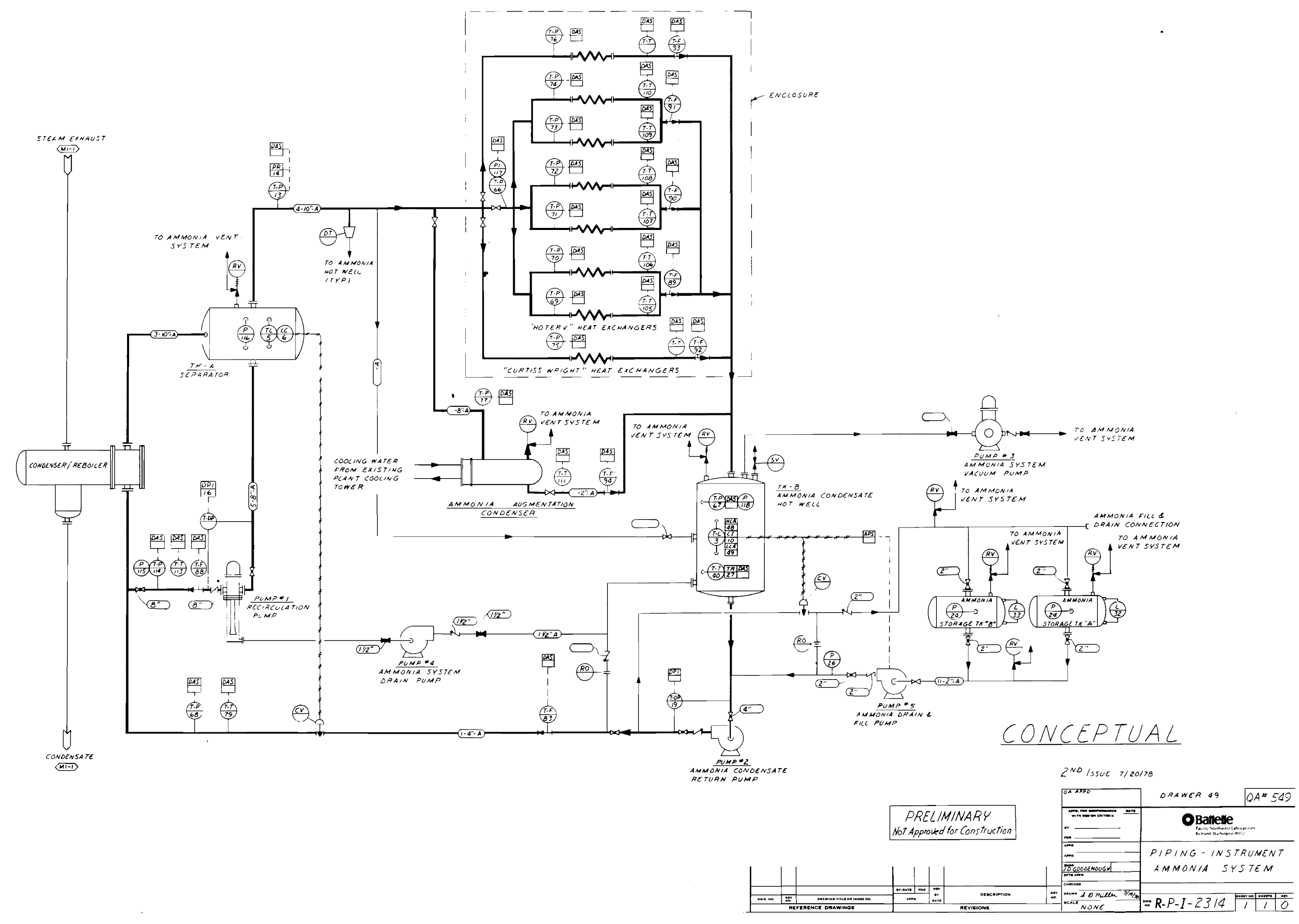




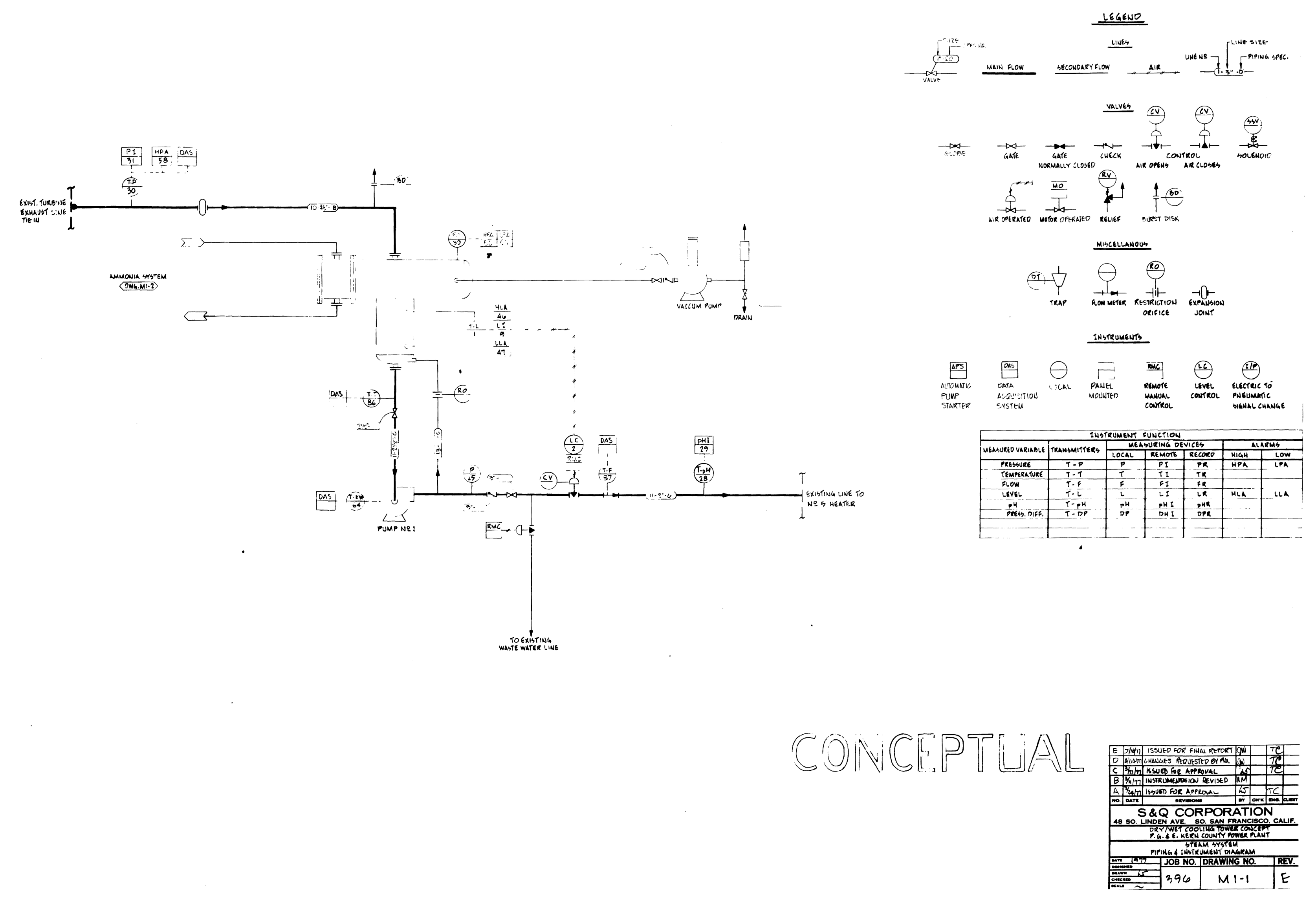
-

- 

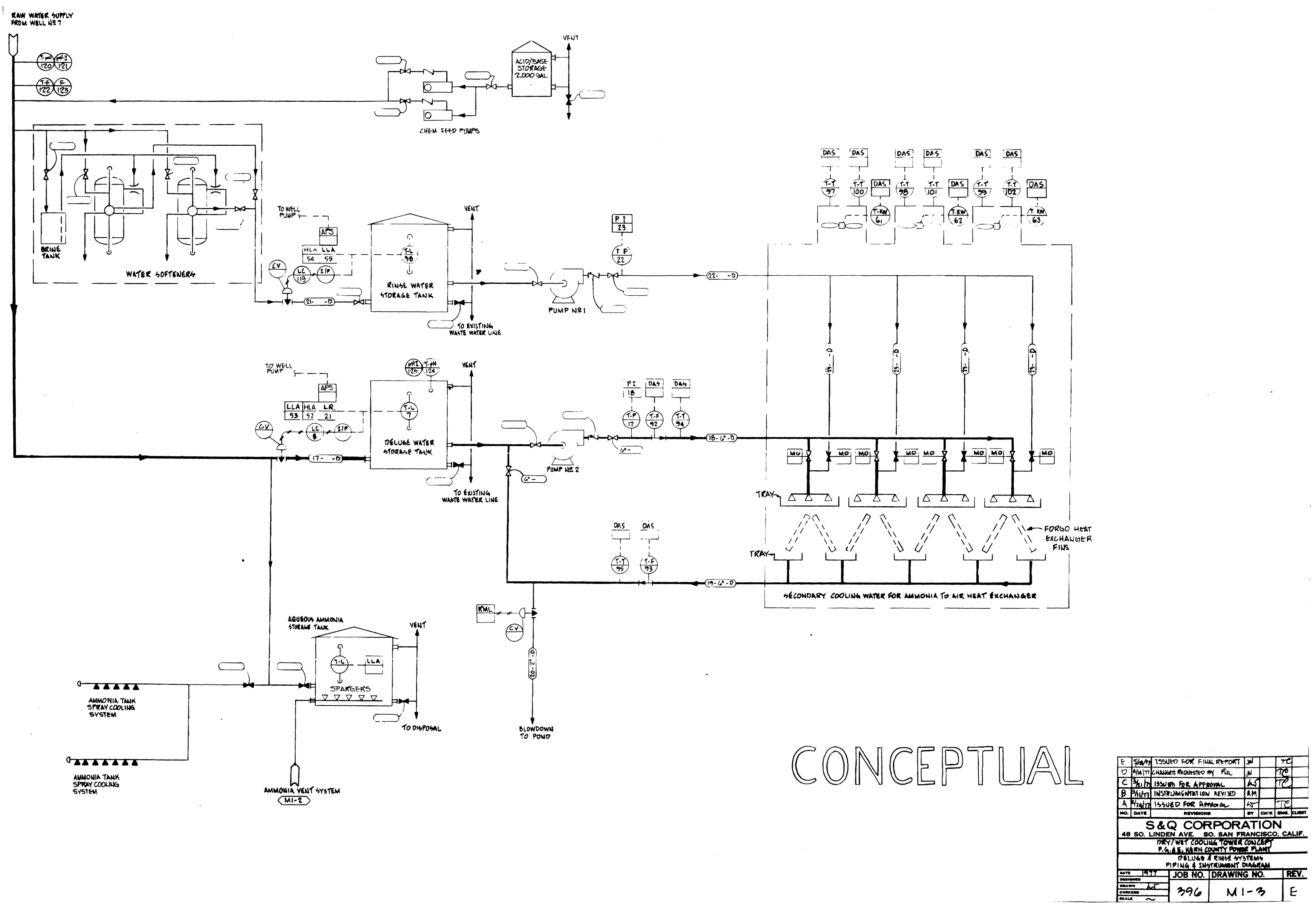


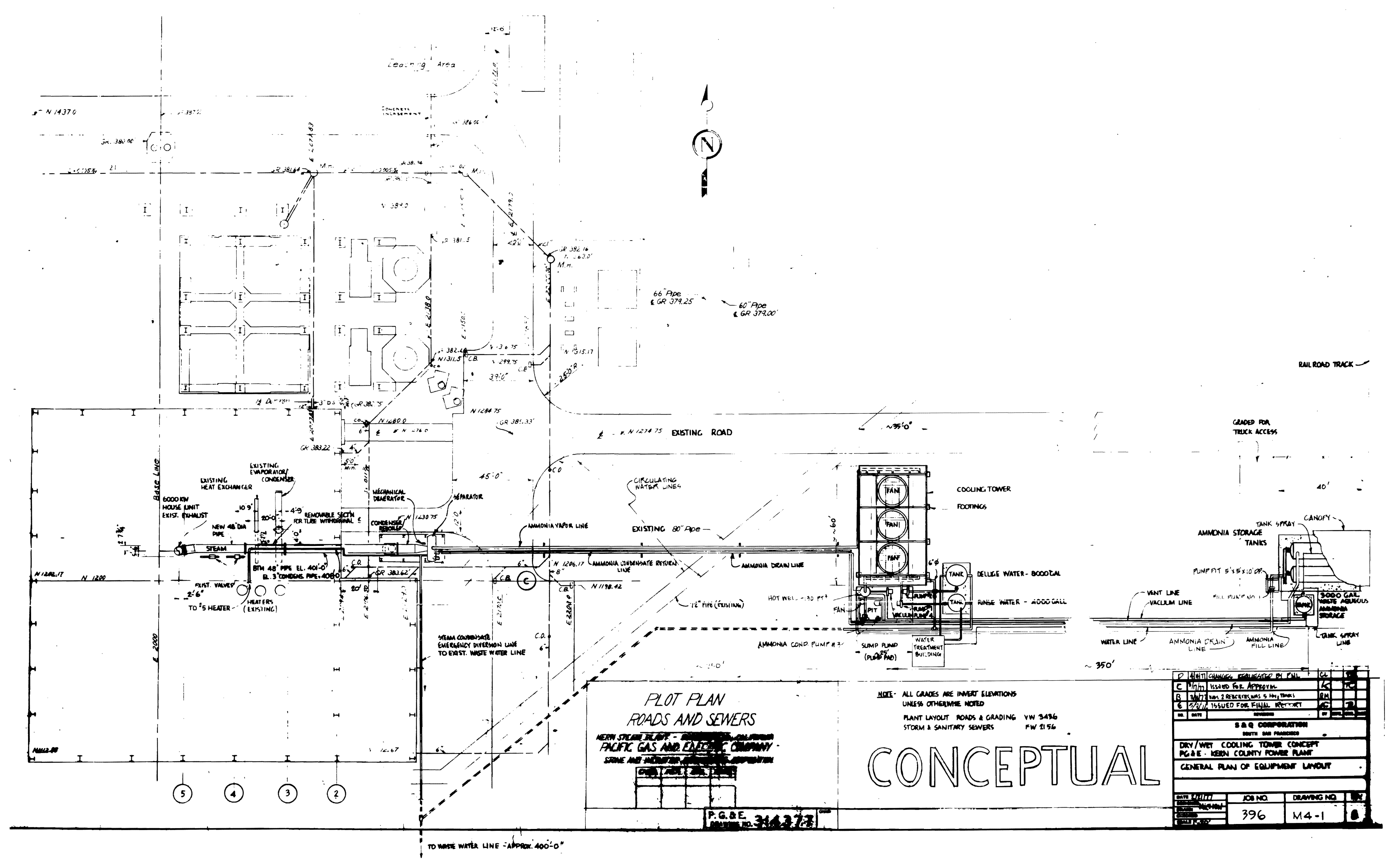




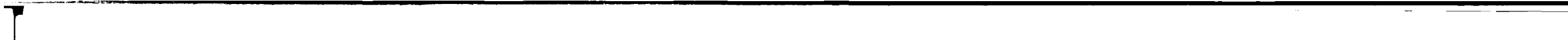




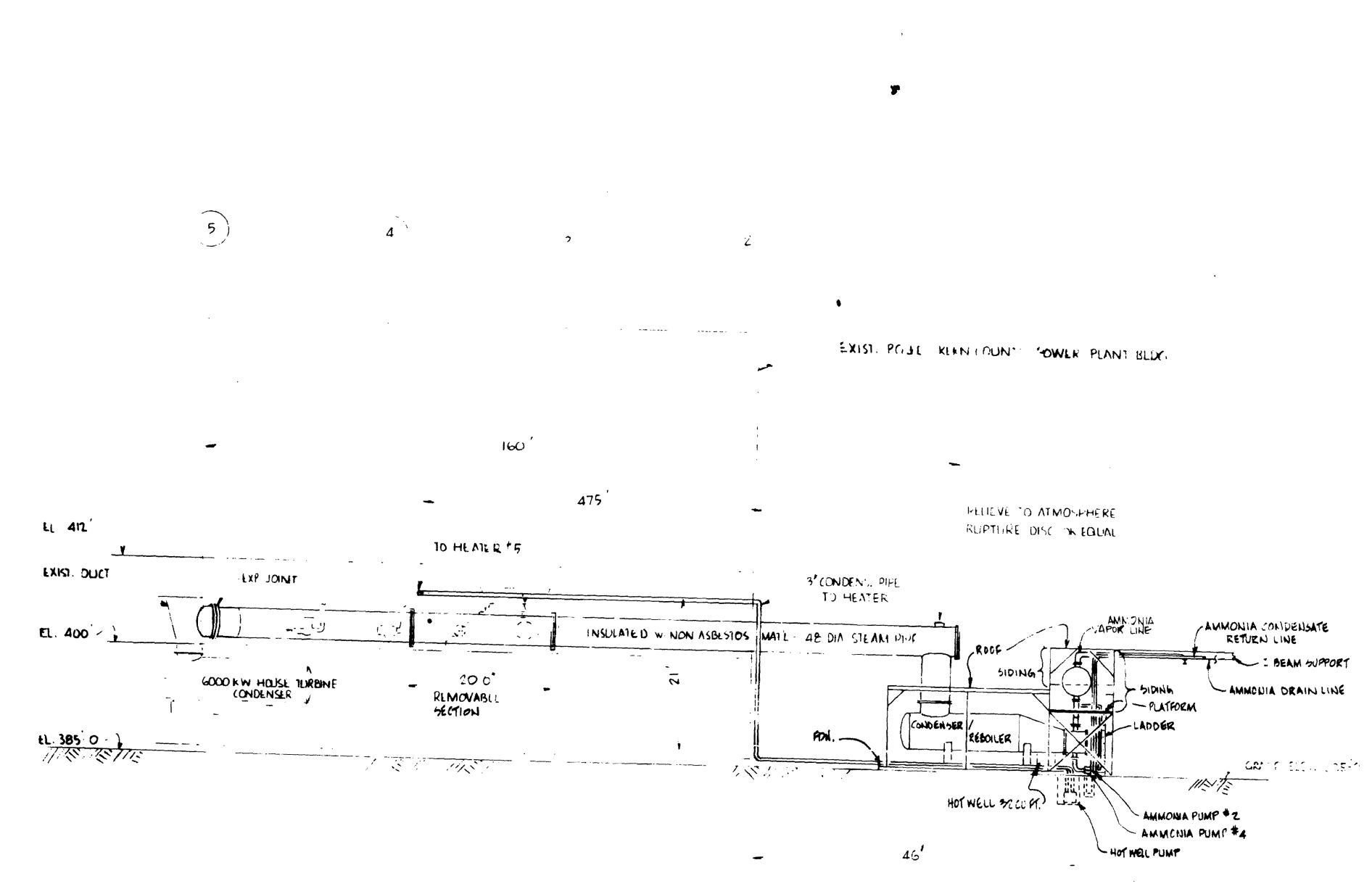

SOUTH HLEVATION (C.NDENSGL RESW".SA AREA)

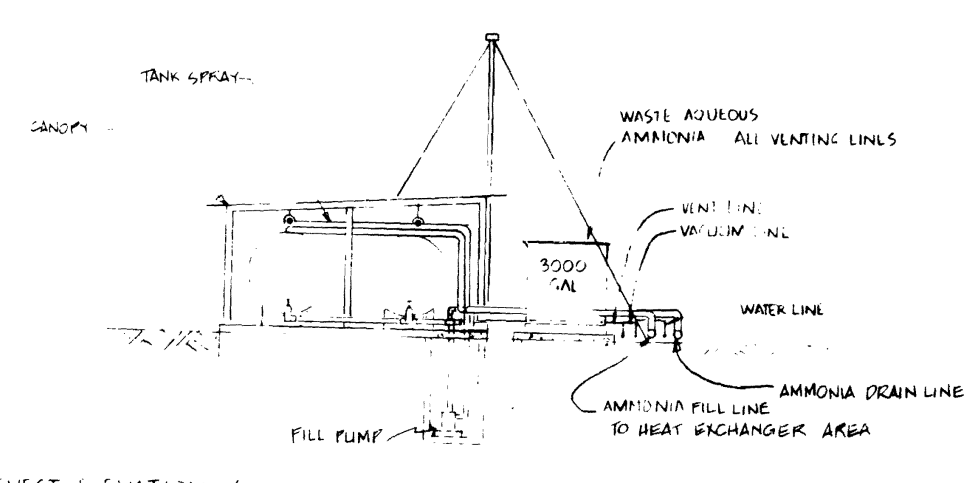

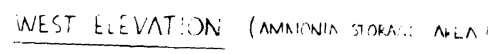

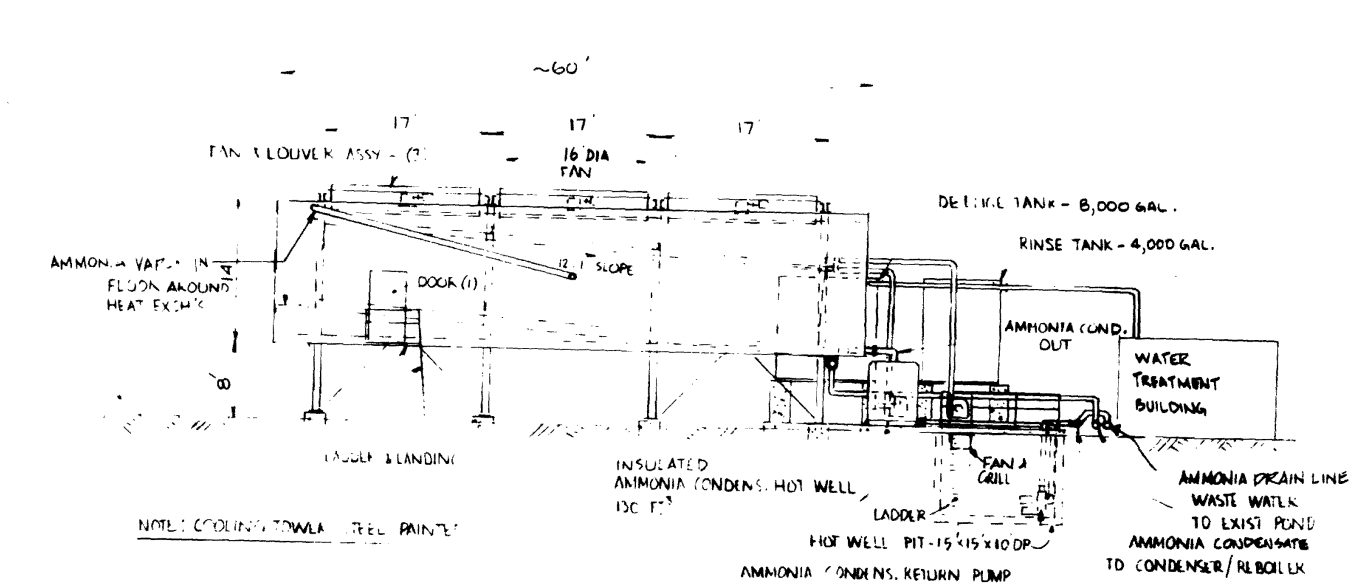

IVEST ELEVATION (COOING. IOWER AREA)

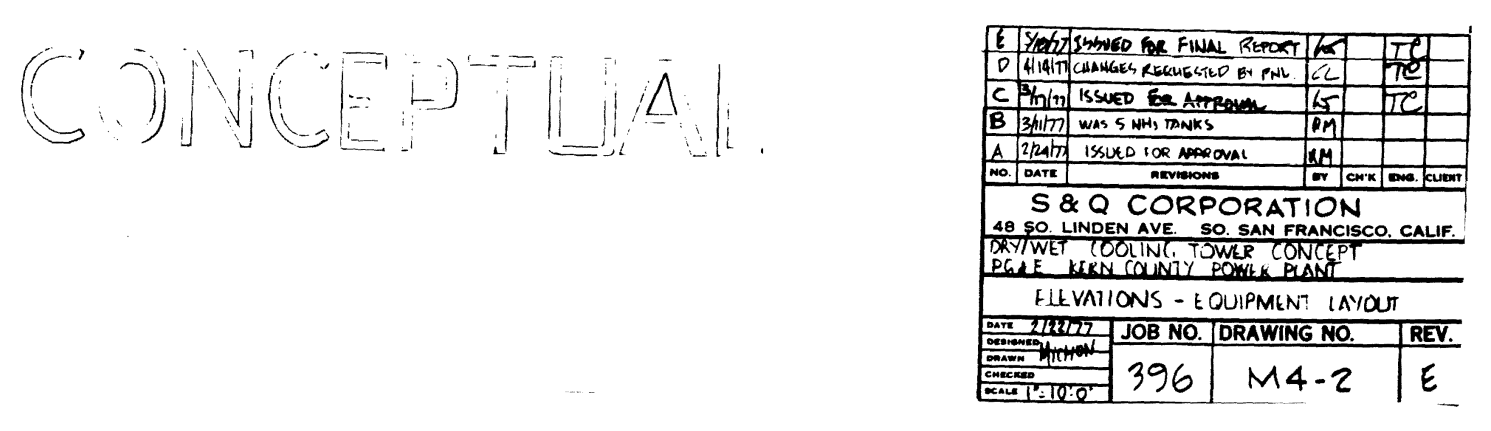

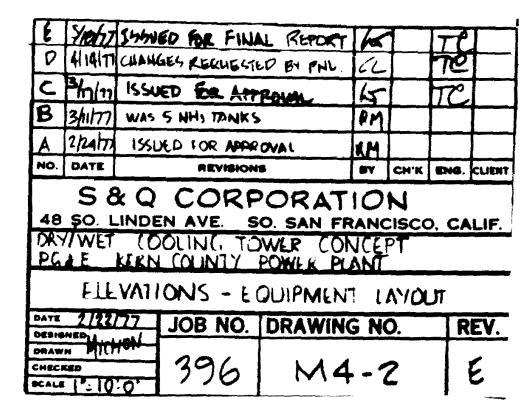




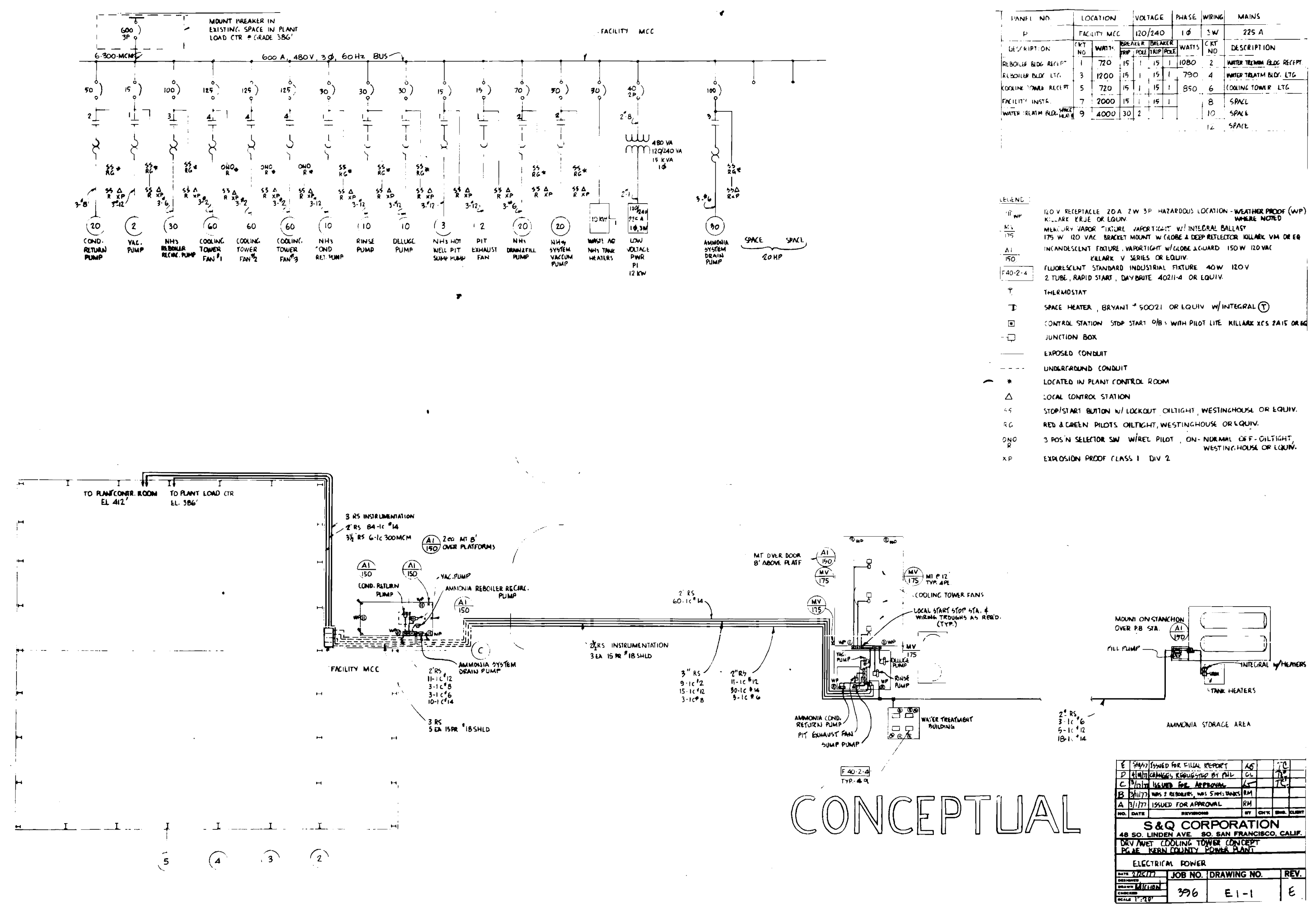
$\times$

n - 


\begin{abstract}
APPENDIX E
ENVIRONMENTAL IMPACT ASSESSMENT

FOR

A FACILITY FOR THE STUDY AND

DEMONSTRATION OF A DRY/WET COOLING

TOWER CONCEPT WITH AMMONIA PHASE-

CHANGE HEAT TRANSPORT SYSTEM
\end{abstract}

BAKERSIFELD, CALIFORNIA

Apri1, 1977

Prepared by

Pacific Northwest Laboratory

Richland, Washington 99352

T. J. McLaughlin 


\section{ENVIRONMENTAL IMPACT ASSESSMENT FOR A FACILITY FOR THE \\ STUDY AND DEMONSTRATION OF A DRY/WET COOLING TOWER \\ CONCEPT WITH AMMONIA PHASE-CHANGE HEAT \\ TRANSPORT SYSTEM}

\section{DESCRIPTION OF THE PROPOSED ACTION}

The Facility for the Study and Demonstration of a Dry/Wet Cooling Tower Concept with Ammonia Phase-Change Heat Transport System (hereafter known as the demonstration facility) will study the use of a deluge/ammonia cooling system in power plant cooling towers for the Dry Cooling Enhancement Program for the Electric Power Research Institute (EPRI). The action includes: construction and installation of cooling towers, a condenser/reboiler, a deaerator, pumps, 12,000 gallon $\left(45 \mathrm{~m}^{3}\right.$ ) ammonia storage vessel(s), a sma 11 water treatment facility, and ancillary equipment adjacent to an existing turbine building at the Kern Power Plant near Bakersfield, California; operation of the demonstration facility to obtain research and development data; and restoration of the site to its original condition.

The actual operation of the facility will redirect all of the exhaust steam from one of the Kern Power Plant 6,000 kW turbines via an exhaust duct field routed to the demonstration facilities' entrance nozzle on top of the condenser/reboiler. As the exhaust steam from the turbine is condensed on the outside of the condenser tubes, the latent heat of condensation will be transferred to boiling anhydrous ammonia being pumped under pressure. This two-phase mixture will be passed through a vapor-liquid separator from which the vapor is sent to an air-cooled condenser tower and the liquid recycled back to the condenser/reboiler. The vapor will flow from the separator to the cooling tower due to the pressure differential between boiling ammonia in the reboiler and condensation in the cooling tower. Heat will be transferred from the condensing ammonia to the atmosphere via conventional forced draft cooling towers with metal tube exchangers. To facilitate operation during cooler periods of the year, the cooling system will be designed to operate as a completely dry system. When air temperature is sufficiently high $\left(55^{\circ} \mathrm{F}, 12.8^{\circ} \mathrm{C}\right)$, a portion of the heat exchanger surface 
will be deluged with water on the outside of the finned tubes to increase the heat rejection capability. A small water treatment building will provide a source of deionized deluge and rinse water.

The demonstration facility will be designed, constructed, and operated to investigate the potential cost savings and to demonstrate its technical performance reliability. The objectives of the program are as follows:

- Develop, in conjunction with the utilities and industry, the technology of dry cooling and combined wet/dry cooling that would improve the siting flexibility of power plants, reduce consumption and thermal pollution of water resources, and minimize degradation of power plant operation.

- Encourage early commercial availability of the most promising cooling system by assuring the development of the required technology base, with minimum cost and risk to the Government and with appropriate industrial participation.

The significant advantages of an ammonia heat transport system include: (1) less cooling tower surface is required since there is a larger heat transfer temperature driving force for the isothermal condensation of ammonia; (2) smaller ammonia vapor transfer lines are required due to the much lower volumetric flow rate and specific volume of ammonia (3) no low temperature safety systems are required in the cooling for ammonia system; and (4) no pumping is required to move vapor to the tower and little power is required to move liquid back to the plant.

Experimental planning calls for the demonstration facility to be operated during intervals of scheduled plant operation. If that is not feasible; the Kern Power Plant may be run especially for the purpose of this testing. Preliminary plans call for demonstration tests ranging in duration from several minutes to several weeks over three Kern Plant operational seasons (i.e., summer only) from 1981 through 1983.

The demonstration facility will be located near Bakersfield, California, at an existing power plant (Kern) owned by Pacific Gas and Electric (PG\&E) Company (see Figure E-1). 


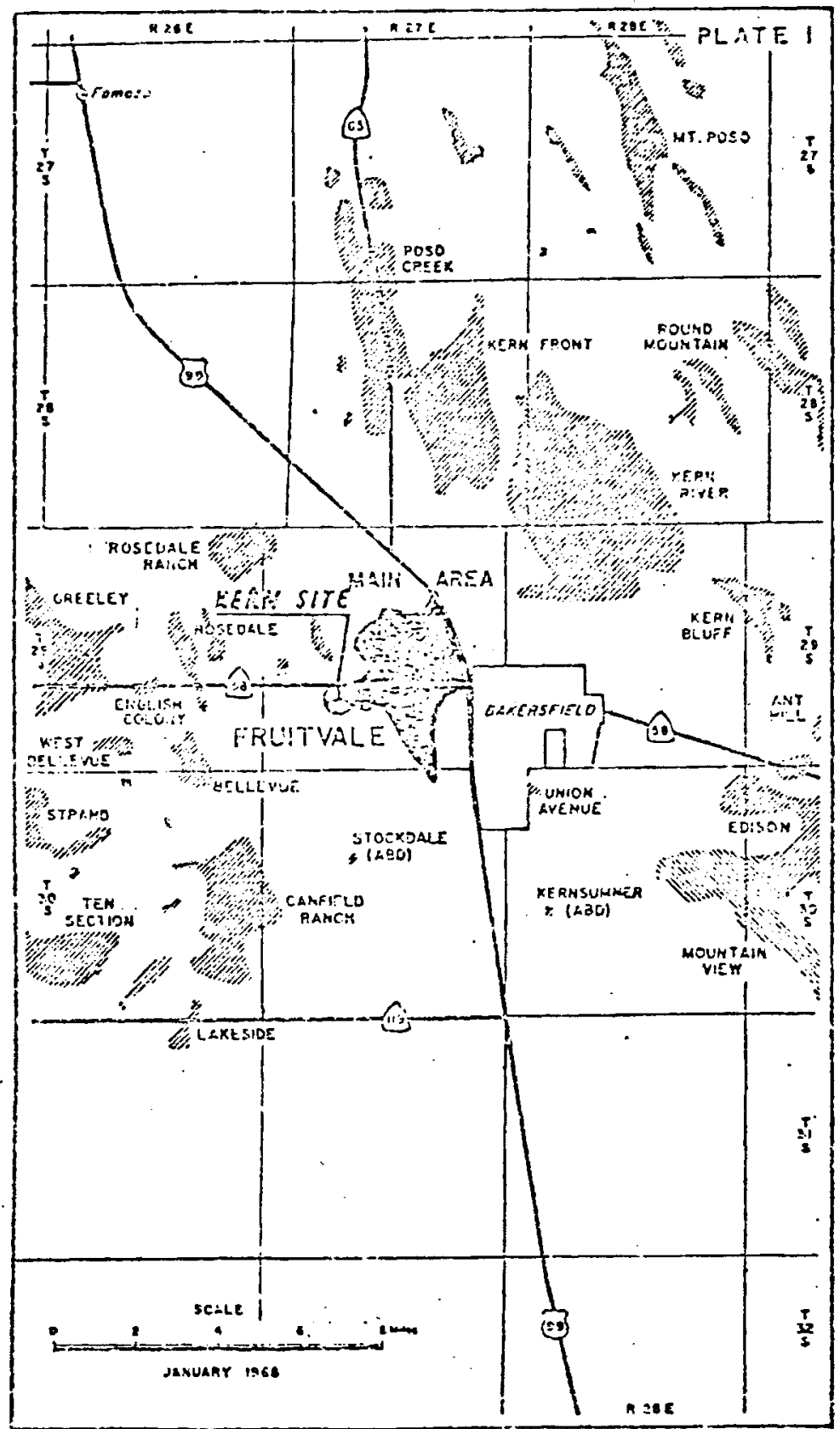

SHF CIL SIELOS
P RRIITVLLE OIL FIELO

FIGURE E-1. Area Map of Kern Power Plant in South Central California Near Bakersfield 
There are no known environmental issues associated with this demonstration facility. Potential ammonia releases will be mitigated through the use of closed system piping from safety, evacuation, and purge valves, that will carry gaseous ammonia to a storage tank in which it will be converted to an aqueous form. The heat of vaporization of steam from one house turbine of the Kern Plant $\left(61.2 \times 10^{6} \mathrm{Btu} / \mathrm{hr}\right)$ will be released to the environs through the cooling towers. No additional steam or heated air will be added as a result of the demonstration facility unless the power plant is not operational during experimental periods. The environmental impact from such releases is expected to be nil. Condensate water will be recycled back to the inlet of the No. 5 heater. Blowdown water from the cooling tower deluge water systems and filter backwash from the water treatment plant will be the only waters released to the environs. The Kern waste pond will receive the water where it will be evaporated rather than released via a point discharge. Since the experiment will utilize existing power plant steam, blowdown water quantities will be similar to those expected during routine Kern Plant operations. No additional aqueous pollutants will result from the demonstration facility. Radioactive products will not be used nor radioactive wastes generated in the experiment. Solid waste quantities generated as a result of the experiment will be quantitatively small and will be predominately office type waste.

\section{DESCRIPTION OF EXISTING ENVIRONMENT}

The demonstration facility will be located 4 miles $(6.4 \mathrm{~km})$ west of downtown Bakersfield, California. The relatively flat site is surrounded by producing and abandoned $0 i 1$ fields and is adjacent to the Fruitvale oilfield. Two oil refineries, one $1 \mathrm{mile}(1.6 \mathrm{~km})$ to the east and one adjacent to the PG\&E property on the southeast, are the heaviest local industry: Zoning is varied adjacent to the site. Property east of Coffee Road (see Figure E-2) is industrial. Although the yellow-brown soil underlain by sand and gravel limits crop quality, agricultural zones surround the site in all directions. The closest single family residence is a house $1 \mathrm{mile}(1.6 \mathrm{~km})$ to the west of the site and a mobile home park within 0.5 miles $(0.8 \mathrm{~km})$ of the site boundary in the same direction. 


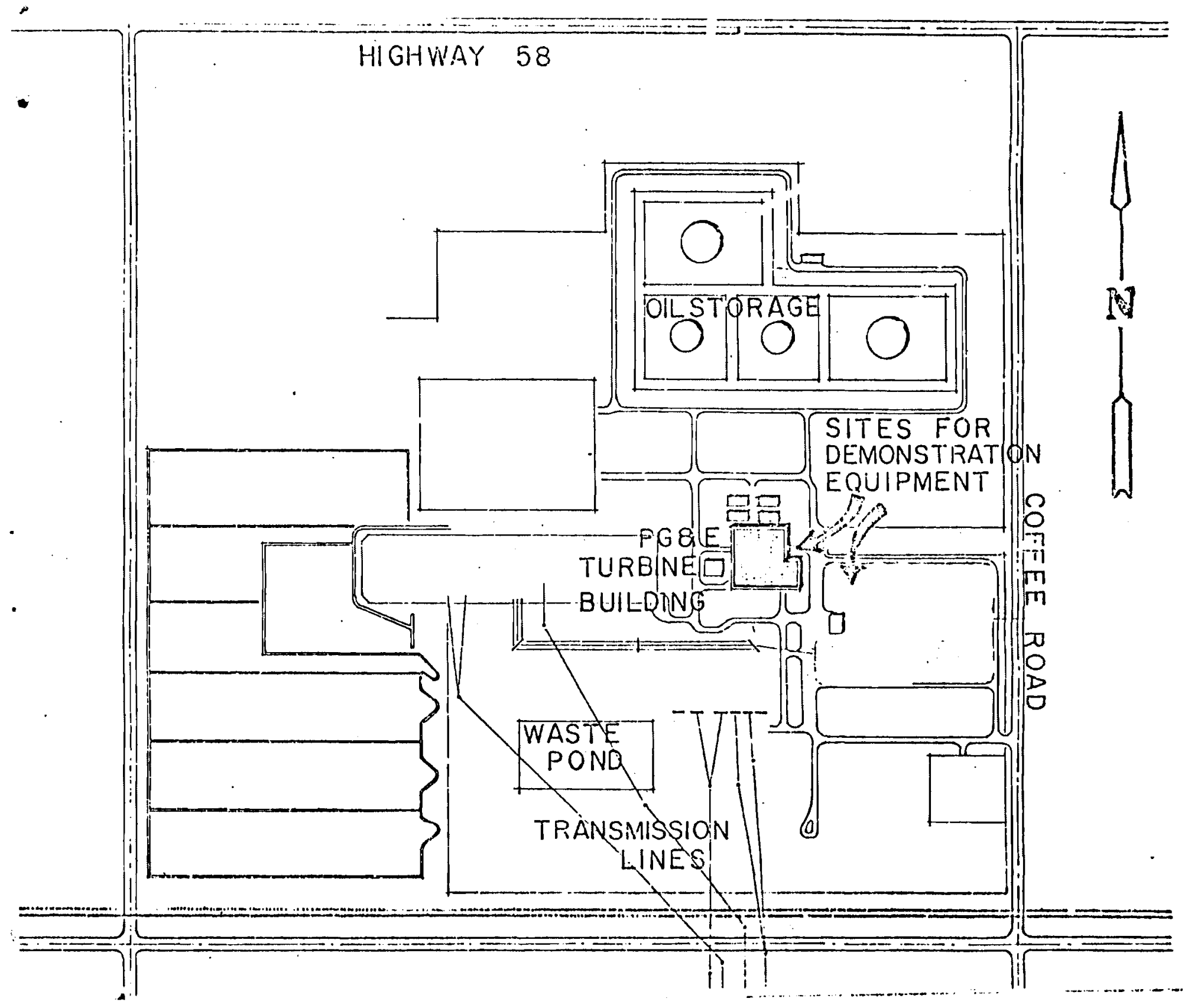

FIGURE E-2. Site Map of Demonstration Facility Location on PG\&E Property 
The Kern Plant, built in 1948, contains two units, each provided with two boilers producing 450,000 pounds $(6,345 \mathrm{~kg})$ of steam per hour, rated nominaliy at 60,000 and 80,000 kilowatts. Major on-site facilities include two 1,800 rpm turbines, four fuel oil storage tanks (240,000 barrel capacity total), five cooling towers, an 80,000 square feet $\left(7,400 \mathrm{~m}^{2}\right)$ waste water drain pond, three wells capable of pumping up to 4,300 gallons per minute (gpm), a 750,000 galion $\left(2,800 \mathrm{~m}^{3}\right)$ water tank, and electrical transmission equipment (see Figure E-2). The facilities in the 2,200 foot by 1,700 foot $(670 \mathrm{~m}$ by $520 \mathrm{~m})$ site are protected by chain link fence. The condenser/ reboiler will be located outside the turbine building east wall with utility access through the wall. The cooling towers, a water treatment facility, and ammonia tanks will be located 220 feet $(67 \mathrm{~m})$ east of the existing turbine building. The ammonia storage tanks will be located 600 feet $(183 \mathrm{~m})$ from the turbine building.

Because the Kern Plant is one of the older plants on the PG\&E system and has an unattractive heat rate in comparison to new plants, it is presently maintained in a cold standby condition; it is only operated during periods of peak system demand and was last operated during the summer of 1977.

The actual construction site is a flat area covered with asphalt, cement, sand, and gravel with little support for vegetation. The area is currently held as an open area and sometimes temporarily used for equipment storage.

The most common mammals seen near the site are ground squirrels, jackrabbits, and domestic sheep which graze on agricultural land near the perimeter fence. The only rare or endangered species seen in the area is the San Joaquin Kit Fox (Vulpes macrotis mutica). Several dens of this fox are thought to inhabit an area one mile $(1.6 \mathrm{~km})$ southeast of the proposed site.

Soils in the area are deep sandy loam underlain by sand and gravel with clay lenses. The closest unconfined water table is approximately 115 feet $(35 \mathrm{~m})$ below the ground surface. The confined aquifer is tapped by the PG\&E wells which draw water from 500 to 970 feet $(152-296 \mathrm{~m})$. 
Existing land uses adjacent to the site vary. Agricultural lands predominate the land use. Mixed with agricultural uses are industrial immediately around the site and to the southeast, residential to the west and northeast and undeveloped to the southwest and east.

Existing ambient noise levels are common to those expected in industrial areas. The majority of noise is attributed to refinery equipment and local motor traffic.

The predominant wind direction is from the northeast and west at an average speed of $5.8 \mathrm{mph}(9.3 \mathrm{kmph})$. Average annual rainfall is 6 inches $(15 \mathrm{~cm})$ with an annual evaporation rate of 108 inches $(275 \mathrm{~cm})$. The mean annual temperature is $65^{\circ} \mathrm{F}\left(18^{\circ} \mathrm{C}\right)$.

The Bakersfield area, in general, is subject to relatively high seismicity. The area is about 30 miles $(50 \mathrm{~km})$ from the San Andres Fault and many other smaller faults. The last major shock was in 1952 with the Arvin-Techachapi earthquake which was magnitude 7.7 on the Richter Scale. The shock and aftershocks were felt throughout southern and central california. Surface rupture was noted near the Kern River east of Bakersfield.

\section{POTENTIAL ENVIRONMENTAL IMPACT}

\section{CONSTRUCTION}

A slight environmental impact may occur as a result of construction of the demonstration facility. Noise will be temporarily increased, but it is doubtful if levels will exceed those generaged by nearby oil refineries. The noise impact on nearby residences will be minimal since the nearest mobile home is at least 2500 feet $(760 \mathrm{~m})$ from the site and construction will be during daylight hours. Mammals will avoid the site and will not have easy access to the fenced area.

No local vegetation will be disturbed since the proposed construction site is covered by gravel. If dust becomes a problem during construction, controlled sprinklin will be used. This is the only potential increase in water use envisioned which may result from the project construction. 
The work force involved in construction of the project will be small enough not to impact heavily upon local services. If anything, the area should benefit economically since the work force will temporarily contribute to the areas of food, entertainment and housing. No additional permanent new housing is anticipated.

Land use will be minimal. Approximately one acre ( 0.4 hectares) will be required for ammonia storage, cooling towers, piping, etc. A small area along the north wall of the turbine building ( 30 by 60 feet, $9 \times 18 \mathrm{~m}$ ) plus an equivalent amount of space inside the building will be required. All construction will be accomplished inside the PG\&E perimeter fence. No earth moving will be required. A small portion of the local sanitary landfill will be required for disposal of equipment packaging and general debris common to construction activities. All solid waste will be transported to the sanitary landfill and will not be open burned. The construction site will be kept clean to preclude unslightly solid waste problems.

The proposed construction site is not on or near an archeological or historic site. Outdoor recreation and wildlife activity will not result from consstruction activities.

OPERATION

The demonstration facility is currently planned to operate a maximum of 1,000 hours per year for three years. Routine operation wil1 not impact upon the surrounding environs. No hazardous air pollutants will be released as a result of routine operations. Heat (maximum $61.2 \times 10^{6}$ Btu or the equivalent of the waste steam from the Kern Plant auxiliary turbine) will be condensed and released to the atmosphere through the demonstration projects cooling tower. Ammonia releases will be mitigated through the use of closed system piping. Any gaseous releases as the result of purging or bleeding will be carried to a tank where it will be dissolved in water to form aqueous ammonia. Since aqueous ammonia is reusable, surplus ammonia will be sold or given to local farmers for use as fertilizer. This would be a beneficial impact resulting from the project. Radioactive materials 
will not be used in this facility. There will therefore be no routine airborne releases of pollutants from operation of the demonstration project. No ambient air quality standards or radioactive concentration guides will be exceeded.

Waste process liquids will be released to the Kern Plant waste pond where it will be held and evaporated. Quantities of liquid waste will not exceed those generated by operation of the older cooling tower from the plant rather than the demonstration project tower. Revisions of environmental permits assigned to the Kern Plant will not be required. Sanitary wastes will be treated by PG\&E septic tanks and drainfields. If the project contributes significantly to the sanitary waste volumes, the septic tanks will be pumped at no expense to PG\&E.

Process water used for the experiment will be cleaner than Kern Plant water after being treated in a small water treatment plant. No biocides will be added.

Solid wastes generated will include office and lunchroom waste and spent resin from the water treatment plant's demineralizer. No environmental impact is expected when wastes are properly disposed in a sanitary landfill.

Impacts from the use of natural resources will be smal1. Experimental plans call for the use of steam during routine Kern Plant operation, if possible. This way, no additional fuel resources will be required for steam generation. Energy and materials will be required to manufacture the equipment and operate the demonstration during test runs.

Because this facility will be a test facility, it will be monitored closely during periods of operation. Any observed failure in equipment or accident will be mitigated by immediate facility shutdown.

The most significant credible accident would be release of ammonia gas to the atmosphere where it potentially would be carried by the wind to grazing sheep, trees, or people. Such an accident would require a major pipe rupture caused by an earthquake, sabotage, or line pressure buildup during demonstration facility operation. In such accidents, no more than 60 seconds would 
be required for personnel to react and shut down the operation after annunciator alarms are activated. Plant personnel will be protected by self-contained breathing apparatus provided by the project. The maximum quantity of anhydrous ammonia released to the atmosphere via this accident scenario would be 2500 pounds $(1125 \mathrm{~kg})$. This quantity is based on the assumption that the facility would be at maximum operation at the time of the accident (i.e., transporting $136,000 \mathrm{lb} / \mathrm{hr}$ of ammonia through the vapor transport system). The release probably would reach ground level immediately after the accident due to the specific gravity of ammonia. The material would be most dangerous to personnel in the immediate area where toxic concentrations existed. Wind and atmospheric conditions would disperse the ammonia to the point where it is doubtful if nearby residents could smell the ammonia. No toxic effects upon any mammal are anticipated. Built-in safety devices and alarms would mitigate significant releases. Such an accident scenario is extremely unlikely since it requires a series of improbable occurrences. No significant accidents are anticipated during this short-term demonstration project.

\section{SITE RESTORATION}

After operation of the demonstration facility, the site will be restored to its original condition and returned to PG\&E. Equipment will be deactivated and released for other uses prior to a burial disposal option. Tie-ins from PG\&E utilities will be patched. After equipment is moved, the site will be restored to its original condition.

No adverse impacts are anticipated as a result of site restoration. There will be beneficial impacts because materials will be returned to the open market at a lower cost. The main demonstration agent, ammonia, will be reused for other purposes.

\section{COORDINATION WITH FEDERAL, STATE AND LOCAL PLANS}

There will be no known or potential conflicts with Federal, State, Regional or Local plans or programs as a result of construction, operation or restoration of the demonstration project. 


\section{DESCRIPTION OF ALTERNATIVES}

The alternatives to the demonstration facilities are (1) to not perform the experiment, (2) to relocate to another site and (3) to delay the action.

The alternative to not perform the experiment would reduce the local environmental impact to zero. The environmental impact of performing the experiment, however, is small compared to the advantages of obtaining data concerning ammonia as a coolant and its possible benefits to the general environment. This alternative would not be acceptable to ERDA in that a goal has been established to accomplish such research through a specific program.

Relocation of the demonstration to other sites has been considered. Proposed site locations are severely limited since operation takes advantage of an existing steam source. The only site found to be acceptable to all parties that would accommodate such research was the Kern Power Plant Site.

The proposed site and construction/operation period are the most practicable alternatives. The Kern Plant layout facilitates relatively easy access into an existing steam supply line without disruption of regular plant operations.

The delaying alternative is unacceptable from an economics viewpoint. Most of the experimental costs are associated with major equipment purchasing, and any delay would elevate the costs significantly because of inflation. 
APPENDIX $F$

APPLICATION OF INDUSTRY PRACTICES

T0

DESIGN OF AN AMMONIA PHASE CHANGE HEAT TRANSPORT

PROCESS PILOT PLANT

FOR

PACIFIC NORTHWEST LABORATORY

By: George L. Henderson

March 18, 1977

Power Generation Cooling Systems 


\section{INTRODUCTION}

Ammonia in the form of liquid or vapor, anhydrous or aqueous, has many industrial applications. These include land fertilization, chemical processes, pulp mills and refrigeration. Satisfactory procedures have been developed over the years for eliminating leakage and corrosion. Equipment operating pressures have been standardized and are used universally. Construction materials have been tested over long periods of time under various conditions so that the satisfactory ones have been determined.

This report contains recommendations for using ammonia as an intermediate heat transport fluid in a dry/wet cooling tower concept, and standard safety and maintenance rules for processes using anhydrous ammonia.

A11 suggestions and data included are based on personal experience in design and operation of plants using ammonia. 


\section{ACCEPTED INDUSTRY PRACTICES FOR LIQUID \\ AND VAPOR AMMONIA PIPING AND EQUIPMENT}

\section{CONSTRUCTION MATERIALS}

Carbon steel is the industry's accepted material for piping, tanks, and heat exchangers. It has satisfactory corrosion resistance for both anhydrous and aqueous ammonia. Stainless steel is also satisfactory, although the expense usually limits its use. Aluminum is satisfactory for ammonia but is subject to concentration pitting in an aqueous phase if particles of other metals are deposited. Copper and copper alloys are subject to rapid corrosion by ammonia.

\section{OPERATING PRESSURES}

The standard setting for ammonia safety valves is $250 \mathrm{psig}$. All piping and equipment which may be exposed to atmospheric temperature must be designed for this pressure. Ammonia systems exposed to higher temperatures are designed for the equivalent pressure of saturated ammonia vapor. Safety valves for these systems are set for the design pressure.

Storage tanks for liquid ammonia are usually designed for 250 psig and are painted with a reflective coating or insulated, and provided with a sun shade. This practice will prevent over-pressurization if ambient temperatures exceed $100^{\circ} \mathrm{F}$ for long periods of time.

\section{FLUID TIGHT INTEGRITY}

Because ammonia can be detected by the human nose at $10 \mathrm{ppm}$ in the air, system tightness is of utmost importance. The most satisfactory piping connections are all welded. The heat exchanger equipment can be designed with welding nozzles for pipe connection.

Most pumps and compressors normally have flanged or threaded connections. Threaded connections are not satisfactory for pipe sizes larger than 1 in. in diameter. If threaded connections are used, the pipe must be heavy wall type, and ammonia pipe sealer must be used for assembly. 
Flanged joints should be the tongue and groove type with lead gaskets.

VAPOR PIPING

Ammonia vapor in pipe lines may, during changes in operating conditions or ambient temperature, partially condense. A mixture of liquid and vapor will be passing through the pipe.

All vapor lines should be continuously graded away from a high point in the line. The liquid must be handled at both ends of the line. Low points in the become liquid traps and must be avoided.

It is common practice to insulate all vapor lines to minimize internal condensation and conversely stop condensation of water vapor on the outside.

Seamless pipe with all welded connections provide the ultimate of fluid integrity. The pipe system is tested with air pressure at design pressure. Each weld is checked using a soap bubble solution. A second test is usually performed with a small amount of ammonia mixed with air at a pressure of 100 psig. Each weld is tested with phenothalein test papaer or with sulfur sticks.

\section{LIQUID PIPING}

If liquid ammonia is transported in a pipe at a temperature below atmospheric, or the pipe is exposed to the ambient air, flashing or vaporization will occur. The mixture of liquid and vapor may cause "water hammer". To prevent this condition, the line must be graded to avoid possible liquid traps.

It is common practice to insulate ammonia liquid lines if the operating pressure may be, at some time, below the saturation pressure of the ambient temperature.

Liquid piping fabrication follows the same rules as those listed for vapor piping. 


\section{EQUIPMENT}

The most common source of ammonia leakage is the rotating seals of equipment. Double mechanical seals with lube oil pressure between them are prone to leak oil into the ammonia; and this oil is deposited on the heat transfer surface creating fouling and decreasing the rate of heat transfer.

Hermetically sealed ammonia pumps that have no rotating seals are now available. Single pumps of the capacity required may not be standard items. It is common practice to use multiple pumps for continuous operation if one pump should fail. Therefore, a bank of three pumps may supply the required capacity and redundancy.

\section{HEAT EXCHANGERS}

When leakage of ammonia into the fluid on the other side of the heat transfer surface is dangerous or detrimental, double tube sheets are used. The most common point of leakage is the tube roll into the tube sheet. Double tube sheets that are double grooved are the safest type of connection. The space between the two tube sheets can be: (1) open to the atmosphere, (L) purged with an inert gas, (3) evacuated, and (4) pressurized with pure steam condensate.

There are two standard systems for connecting tubes to tube sheets. Carbon steel tubes can be welded to the tube sheet, but have as the following disadvantages: (1) repair of a weld leak is very difficult, and (2) welds crack under temperature strains and develop leaks after the leak test has been completed.

Tubes rolled into double-grooved tube sheets can be tightened if a leak is found after installation.

The air and ammonia test described should be used to test heat exchanger fluid integrity at the fabrication plant.

All heat exchange tubing, either steel or aluminum, should be seamless with no welds either circumferential or longitudinal. 


\section{EQUIPMENT FABRICATION}

A11 ammonia equipment must be designed and fabricated to meet the ASME Code for Unfired Pressure Vessels. As noted, it is preferable that all nozzles be the type for welded connections.

A11 tank pump suction nozzles should be equipped with internal weirtype fittings to assure solid liquid to the pump, even at minimum NPSH conditions. Al1 pumps must be located far enough below the tank to provide the required NPSH for boiling liquid.

\section{NONCONDENSABLE PURGES}

Practically a 11 of the noncondensables and gases in an ammonia system are heavier than ammonia vapor at the same pressure. Therefore, the most efficient point to purge these gases from the system is just above the liquid ammonia level in the tank that collects the condensed ammonia vapor.

\section{INSTRUMENTATION}

It is common practice to use open-gage glasses on ammonia systems with these precautions: (1) the gage glass shutoff valves contain flow rate check valves for automatic shutoff in case of glass breakage, and (2) the glass is protected by a steel pipe guard with a slot for viewing the level.

No copper or copper alloy can be exposed to the ammonia. All pressure gages use stainless steel bellows or Bourdon tubes. Stainless steel diaphragms are used to protect instruments that may be exposed to ammonia. Orifice type flowmeters must use steel tubing from orifice flanges to the meter.

VALVES

Standard ammonia shutoff valves are globe type with lead seats.

Gate valves do not provide satisfactory shutoff. Ball valves can be used if the elastomer can stand ammonia. Lubricated plug cocks are a 
possible choice but the lubricant will eventually get to the heat transfer surface and degrade operation.

The ASME Code specifies a formula to be used for sizing the safety valves to match the tank or equipment volume. Common practice uses double safety valves mounted on a 3-way valve so that a safety valve can be removed and replaced while operation continues and the second safety valve provides protection.

Standard ammonia safety valves have lead seats.

Noncondensable purges and safety valve discharge pipes must be connected to a tank containing fresh water. The water will absorb the ammonia discharged to it. The ammonia absorbing tank operates at atmospheric pressure. The tank size can be calculated from the discharge rate of the largest safety valve. 


\section{SAFETY AND MAINTENANCE RULES}

Ammonia is an alkali and will burn if allowed to touch the skin, especially damp skin such as sweaty areas. Flood with water to stop the reaction. Small amounts of ammonia vapor in the air are very irritating to the nose and eyes and its distinctive odor warns of the amount present in the air. Ten ppm can be smelled by the ordinary person. Anhydrous ammonia is a liquified gas and must be contained under pressure at atmospheric temperatures.

\section{OPERATING SAFETY}

When handled correctly, equipment containing ammonia can be nperated and maintained as safely as machinery working with plain water. The follow ing safety rules must be observed:

a. Before opening or closing any valve, double check the pressure above the valve and the location of the valve discharge.

b. Never open a pipe line unless the pressure has been pumped or bled down to atmospheric.

c. Do not climb or pull on piping containing ammonia, or the pipe may break. Smál1 piping, especially $1 / 4,3 / 8$, and $1 / 2$ in. should be treated with great care, as a break can cause loss of life or serious injury.

d. To reduce the pressure in a line, a bleed valve can be arranged with a pail of water so that the gas is slowly purged into the water and only a negligible amount will escape into the air because water absorbs ammonia very rapidly.

e. To tighten packing glands on gage glasses, turn off the gage cocks so that the ammonia will not escape if you break the gage glass.

f. Always wear goggles when working with equipment which contains ammonia under pressure. Always wear an ammonia gas mask when opening any part of a system which has contained ammonia. Always take a position upwind of the connection in work. 
g. When opening an ammonia connection, do not stand in a corner where you are trapped if some gas escapes.

h. Always open valves, unions and fittings very slowly so that you can tighten up again if necessary.

i. It is always safer and less time-consuming to carefully purge the equipment of ammonia before starting work, as the time waiting for the air to clear after a spill affects everyone in the area.

j. Wash out the equipment removed with water, then dry and oil machined surfaces to protect them from rust.

Standard ammonia gas masks must be provided at each operator location and placed so that a person can reach them without entering the contaminated area. A minimum of two self-contained breathing units are required for the area. They should be located near the ammonia process in a spot protected from possible contamination. A set of impermeable clothing should be used with this self-contained unit.

Flooding the ammonia leak or rupture with water will clear the air efficiently. Therefore, water hydrants equipped with hoses should be located so that any part of the process can be covered with water if a leak occurs. The deluge system will handle any ammonia leak in the ammonia condenser area efficiently. A sprinkler system under the roof of the reboiler area would be very effective against leaks in that area.

Good maintenance procedures on a well constructed plant will practically eliminate an accidental release of ammonia.

In practice, most ammonia is released during repair or revision work on the process. Correct procedures for draining and purging the system will eliminate this possibility. Even if a leak does occur, immediate flooding with water will eliminate any hazard. 


\section{MAINTENANCE RULES}

a. Keep all valve stems greased to prevent corrosion. Stainless steel valve stems are sometimes used for ammonia but lubrication is still required.

b. Keep all valve packing gland threads greased to prevent corrosion. If allowed to corrode, adjusting the gland to prevent a leak could be dangerous if failure occurs.

c. Check all packing glands and pipe unions such as gasketed flanges for smali leaks--use test papers or sulfur tapers once each day.

d. Maintain the paint on all bare equipment and pipe lines to prevent corrosion.

e. Check the condition of pipe insulation at least monthly and repair as needed. 
PNL-2715

UC-12

\section{DISTRIBUTION}

No. of

Copies

\section{OFFSITE}

U.S. Department of Energy

A. A. Churm

Chicago Patent Group

9800 South Cass Avenue

Argonne, IL 60439

U.S. Department of Energy

Office of Assistant General

Counsel for Patents

Washington, DC 20545

27 DOE Technical Information Center

10 U.S. Department of Energy

I. Helms

Advanced Concepts Evaluation Branch - G-434

Division of Advanced Systems and Materials

Washington, DC 20545

U.S. Department of Energy

W. F. Savage

Chief, Advanced Concepts

Evaluation Branch

Division of Advanced Systems and Materials

Washington, DC 20545

U.S. Department of Energy

D. C. Bauer

Director, Division of Advanced Systems and Materials Washington, DC 20545

U.S. Department of Energy

R. B. Morrow

Special Projects Branch

Division of Advanced Systems and Materials

Washington, DC 20545
No. of

Copies

\section{U.S. Department of Energy}

N. Gerstein

Chief, Special Projects Branch

Division of Advanced Systems and Materials

Washington, DC 20545

U.S. Department of Energy

W. E. Mott

Director, Energy Control Technology

Division of Biomedical and Environmental Research

Washington, DC 20545

U.S. Department of Energy

G. A. Newby

Assistant Director, Office of

Technical Development

Division of Advanced Systems and Materials

Washington, DC 20545

Allied Chemical Company

B. R. Dickey

550 2nd Street

Idaho Falls, ID 83401

Allis-Chalmers Power Systems, Inc.

J. S. Joyce

1135 South 70 th Street

West Allis, WI 53214

Aluminum Company of America

E. T. Wanderer

Alcoa Technical Center

Alcoa Center, PA 15069

American Electric Power

H. J. Janzon

2 Broadway

New York, NY 10004

American Electric Power Service Corporation

C. Swens on

2 Broadway

New York, NY 10004 
No. of

Copies

Aqua-Chem

R. M. Ahlgren

P.0. Box 421

Milwaukee, WI 53201

Arizona Public Service Co.

W. E. Campbell

P.0. Box 21666

Phoenix, AZ 85036

Arizona Public Service Co.

T. Woods

2121 W. Cheryl Drive

Phoenix, AZ 85021

Babcock \& Wilcox

M. W. Peterson

Fossil Power Division

20 South Van Buren

Barberton, $\mathrm{OH} 44203$

Baltimore Aircoil Co., Inc.

E. Schinner

P.0. Box 7322

Baltimore, MD 21227

Baltimore Gas \& Electric Co.

G. C. Creel

Gas \& Electric Building

Baltimore, MD 21203

Battelle-Geneva

J. P. Budliger

7 Route De Drizi

1227 Geneva, SWITZERLAND

Bechtel Corporation

$P$. Leung

P.0. Box 60860

Terminal Annex

Los Angeles, CA 90060

Bechtel Corporation

G. R. Reti

P.0. Box 3965

San Francisco, CA 94119
No. of

Copies

R. W. Beck and Associates

J. P. Rossie

400 Prudential Plaza

Denver, C0 80202

Betz Environmental Engineers

J. Soost

$9317 \mathrm{~J}$, Highway 99

Vancouver, WA 98665

Black, Crow and Eidsness, Inc.

C. G. Thompson

807 South McDonough

Montgomery, AL 35104

Black Hills Power and Light Company

B. Westre

P.0. Box 1400

Rapid City, SD 57701

Boeing Aerospace Division

D. Gilbert (M.S. 2R00)

P.0. Box 3999

Seattle, WA 98124

Bonneville Power Administration

E. H. Hall

1002 N.E. Holladay Street

Box 3621

Portland, OR 97208

Burns and Roe, Inc.

700 Kinder Kamack Rd.

Oradel, NY 07649

California Energy Commission

C. Webb

1111 Howe Avenue

Sacramento, CA 95825

California State Energy Resources Conservation and Development Commission

L. E. Stamets

1111 Howe Avenue

Sacramento, CA 95825 
No. of

Copies

Carolina Power \& Light Co. J. Sell

336 Fayettesville Street

Raleigh, NC 27602

Catalytic Construction Corp.

J. Morse

P.0. Box 11402

Charlotte, NC 28029

Ceramic Cooling Tower Co.

P. A. Frohwerk

P. 0. Box 425

Fort Worth, TX 76101

Chicago Bridge and Iron Company

C. T. Bouchard

Route 59

Plainfield, IL 60544

Combustion Engineering Lummus Engineering Company

R. J. Croke

1515 Broad St

Bloomingfield, NJ 07003

Columbus and Southern Ohio

Electric Co.

L. W. Meridith

General Manager, Generation

Department

215 North Front Street

Columbus, $\mathrm{OH} 43215$

Combustion Engineering

H. H. Osborn

Air Preheater Company

Wellsville, NY 14895

Commonwealth Edison

R. H. Holyoak

One First Plaza

P.0. Box 767

Chicago, IL 60690

Consolidated Edison Co. of New York, Inc.

W. A. Messner

4 Irving $\mathrm{Place}$

New York, NY 10003
No. of

Copies

Consolidated Edison Co. of New York, Inc.

C. L. Newman

4 Irving Place

New York, NY 10003

Cornell University

F. K. Moore

Ithaca, NY 14850

Curtiss-Wright Corporation

R. J. Haberski

One Passaic Street

Wood Ridge, NJ 07075

Dames \& Moore

L. Craton

Suite 1000

1100 Glendon Avenue

Los Angeles, CA 90024

Dames \& Moore

P. Gottlieb

Suite 1000

1100 Glendon Avenue

Los Angeles, CA 90024

Delmarva Power \& Light

F. Cook

800 King Street

Wilmington, DE 19801

Dow Chemical Company

E. Wagener

2800 Mitchel1 Drive

Walnut Creek, CA 94598

Duke Power Company

S. K. Blackley

P.0. Box 2178

Charlotte, NC 28201

Duquesne Light Co.

J. Latshaw

435 6th Avenue

Pittsburgh, PA 15219

Dynatech Company

E. Guyer

99 Erie Street

Cambridge, MA 02139 
No. of

Copies

Ecodyne

J. Slotnik

607 First Street, S.W.

Massilion, $\mathrm{OH} 44646$

Ecodyne Cooling Products Co.

J. K. Swindt

P. 0. Box 1267

Santa Rosa, CA 95403

Ecodyne Cooling Products

K. D. Whitehead

P. 0. Box 1267

Santa Rosa, CA 95403

Electric Power Research Institute

J. Maulbetsch

3412 Hi 11 view Avenue

P.0. Box 10412

Palo Alto, CA 94304

Empire State Electric Energy Research Corp.

L. Geller

1271 Avenue of the Americas

New York, NY 10020

Environmental Protection Agency

T. G. Brna (MD-61)

IERL/RTP

Research Triangle Park, NC 27711

Environmental Protection Agency

A. Galley (WH-552)

401 M. Street SW

Washington, DC 20460

Environmental Protection Agency

M. Maxwe11 (MD-61)

IERL/RTP

Research Triangle Park, NC 27711
No. of

Copies

Environmental Protection Agency

F. H. Rainwater

Pacific Northwest Water Laboratory

200 S.W. 35th Street

Corvallis, OR 97330

Environmental Protection Agency

F. A. Roberts

200 S.W. 35th Street

Corvaliis, OR 97330

Environmental Sciences and Services

W. G. Hoydysh

150 East 73rd Street

New York, NY 10021

Environmental Systems Corporation

K. Wilber

P.0. Box 2525

Knoxville, TN 37901

ERG Incorporated

G. M. Benson

Lowe11 57th Street

Oakland, CA 94608

Exxon Research Center

J. G. Stevens

Bldg. 1, Rm. 2048

P.0. Box 8

Linden, NJ 07036

Federal Power Commission

E. Sligh

825 N. Capitol Street

Washington, DC 20426

Florida Power \& Light Co.

$C$. Henderson

9250 W. Flagler Street

Miami, FL 33174 
No. of

Copies

Foster Wheeler Energy Co.

E. L. Damon

$110 \mathrm{~S}$. Orange Avenue

Livingston, NJ 07039

Franklin Institute

A. M. Rubin

Twentieth \& Parkway

Philadelphia, PA 19103

Frick Company

J. Bibcoff

15302 El Mar Lane

Kerman, CA 93630

GEA Airexchangers, Inc.

B. Davis

P.0. Box 1377

Thomasville, GA 31792

General Atomic Company

A. C. Eulberg

P.0. Box 81608

San Diego, CA 92138

General Electric Co.

E. H. Miller

Large Steam Turbine Division

300 Nott Street

Schenectady, NY 12301

General Motors Corp.

R. K. Shah

Harrison Radiator Division

Lockport, NY 14094

Georgia Power Co.

T. E. Byerley

P.0. Box 4545

Atlanta, GA 30302

Gilbert Associates, Inc.

J. F. Sebald

525 Lancaster Avenue

Reading, PA 19603

Heat Transfer Research Inc.

J. E. Taborek

1000 S. Fremont Avenue

Alhambra, CA 91802
No. of

Copies

Hudson Products

M. W. Larinoff

6855 Horwin Drive

Houston, TX 77036

Hudson Products

E. C. Smith

6855 Horwin Drive

P.0. Box 36100

Houston, TX 77036

H2M Corporation

H. D. Freudenthal

500 Broad Hollow Road

Melville, NY 11746

Ingersol1-Rand

W. R. Scott, Jr.

Phillipsburg, NJ 08865

Ital impianti-Societa

Italiana Impianti p.a.

C. Rocco

Piazza, Piccapietra 9

18121 Genoe, ITALY

Los Angeles Department of Water and Power

J. L. Mulloy

111 N. Hope Street

Los Angeles, CA 90012

Louisiana Power \& Light Co.

D. L. Aswel1

142 Delaronde Street

New Orleans, LA 70174

The Charles T. Main Co.

E. S. Miliaras

Southeast Tower

Prudential Center

Boston, MA 02199

Marley

C. A. Baird

12 S. 12th Street

Philadelphia, PA 19107 
No. of

Copies

Marley

J. D. Holmberg

5800 Fox Ridge Drive

Mission, KS 66202

Marley

R. Landon

5800 Fox Ridge Drive

Mission, KS 66202

Martin Marietta Laboratories

$L$. Bongers

1450 South Rolling Road

Baltimore, MD 21227

Massachusetts Institute of Technology

L. R. Glicksman

77 Massachusetts Avenue

Cambridge, MA 02139

Massachusetts Institute of Technology

M. W. Golay

77 Massachusetts Avenue

Cambridge, MA 02139

Massachusetts Institute of Technology

R. Harleman

Department of Civil Engineering

77 Massachusetts Avenue

Cambridge, MA 02139

McDonnell Douglas Astronautics Co.

W. H. P. Drummond

5301 Balsa Avenue

Huntington Beach, CA 92647

McDonnell Douglas

Astronautics Co.

S. O'Hare

5301 Balsa Avenue

Huntington Beach, CA 92647
No. of

Copies

Minnesota Power Cooperative, Inc.

L. A. Hillier

Box 1318

Grand Forks, ND 58201

Montana Power Co.

R. Hofacher

40 E. Broadway

Butte, MT 59701

Niagara Blower

W. Kals

405 Lexington Avenue

New York, NY 10017

Northeast Utilities

R. H. Meyer

P.0. Box 270

Hartford, CT 06101

Northern States Power Co.

R. Stansfield

414 Nicollet Mall

Minneapolis, MN 55401

N.U.S. Corporation

S. Lefton

2 Palo Alto Square (Suite 624)

Palo Alto, CA 94304

Oak Ridge National Laboratory

J. W. Michel

OTEC Heat Exchange Project

Activity

Box Y

Oak Ridge, TN 37830

Orange \& Rockland Utilities, Inc. R. H. Metzger

Environmental Services Manager

75 West Route 59

Spring Valley, NJ 10977 
No. of

Copies

Oregon State University

L. P. Davis

Department of Mechanical

Engineering

Corvallis, OR 97330

Oregon State University

C. E. Wicks

Department of Chemical

Engineering

Corvalis, OR 97330

Oregon State University

J. G. Knudson

Engineering Experiment Station

Corvallis, OR 97330

Pacific Gas \& Electric

A. A. Ariey

77 Beale Street

San Francisco, CA 94106

Pacific Gas \& Electric

F. F. Mautz

77 Beale Street

San Francisco, CA 94106

Pacific Power \& Light Co.

W. C. Bruaer

Public Service Bldg.

Portland, OR 97204

Pennsylvania Power \& Light

W. Dussinger

2 North Ninth Street

Allentown, PA 18101

Pennsylvania Power \& Light

D. G. Pfeiffer

2 North Ninth Street

Al lentown, PA 18101

PFR Engineering Systems, Inc.

T. Rozenmann, President

Suite 832

4676 Admiral ty Way

Marina del Rey, CA 90291
No. of

Copies

Philadelphia Electric Co.

J. Allen

2301 Market Street

Philadelphia, PA 19101

Philadelphia Electric Co.

S. J. Kowalski

2301 Market Street, NZ-1

Philadelphia, PA 19101

Philadelphia Electric Co. J. B. Mache1

2301 Market Street, NZ-1

Philadelphia, PA 19101

Philadelphia Electric Co. D. Marano

2301 Market Street, NZ-1

Philadelphia, PA 19101

Prof. Ing. Carlo Roma

Piazza delle Muse 8

Rome, ITALY

Pickard Low \& Garrick

L. Rust

1200 18th St. NW

Suite 612

Washington, DC 20036

Power Generation Cooling Sys tems

G. L. Henderson

4714-52nd Street S.

Seattle, Wa 98118

Public Service of Colorado

R. F. Walker

5900 E. 39th Avenue

Denver, CO 80207

Public Service Company of Indiana

S. W. Shields

V. P. Engineering

100 E. Main Street

Plainfield, IN 46168 
No. of

Copies

Public Service Company of New Mexico

C. D. Bedford

P.0. Box 2267

Albuquerque, NM 87103

Public Service Company of New Mexico

J. D. Maddox Corporate Planning Dept.

Albuquerque, NM 87103

Quirk, Lawler and Mattusky, Eng.

J. Lawler

5055 th Avenue

New York, NY 10017

Radian Corporation

F. B. Mesich

P.0. Box 9948

Austin, TX 78766

Research Cottre11

G. E. Collins

Hamon Cooling Tower Division

Box 750

Bound Brook, NJ 08805

Research Cottre11

R. H. Hannon

Hamon Cooling Tower Division

Box 750

Bound Brook, NJ 08805

Resources Conservation Company

$H$. Herrige 1

P. 0. Box 936

Renton, WA 98055

Resources for the Future

D. Abbey

1755 Massachusetts Avenue NW Washington, DC 20036
No. of

Copies

Reynolds Aluminum Co.

R. Lindberg

Reynolds Metallurgical

Research Laboratory

Richmond, VA 23261

Richmond Field Station

H. H. Sephton

47 th and Hoffman Blvd.

Richmond, CA 94804

San Diego Gas \& Electric

R. G. Lacy

101 Ash Street

San Diego, CA 92107

Seattle City Light

T. R. Miller

Principal Mechanical Engineer

1015 Third Avenue

Seattle, WA 98104

Seattle City Light

R. G. Sheehan

1015 Third Avenue

Seattle, WA 98104

Southern California Edison

R. S. Currie

2244 Walnut Grove Avenue

Rosemead, CA 91770

Southern California Edison

W. C. Martin

2244 Walnut Grove Avenue

Rosemead, CA 91770

Southern California Edison

F. A. McCracken

2244 Walnut Grove Avenue

Rosemead, CA 91770

Southern Services, Inc.

C. H. Goodman

P.0. Box 2625

Birmingham, AL 35202 
No. of

Copies

P. Sporn

Consultant Engineer

74 Trinity Pl., Suite 511

New York, NY 10006

Stanford University

A. L. London

Department of Mechanical

Engineering

Stanford, CA 94305

Stearns-Rogers, Inc.

J. Y. Parce

Box 5888

Denver, C0 80217

Stewart-Warner Corporation

South Wind Division

V. N. Tramontini

1514 Dover Street

Indianapolis, IN 46221

Stone \& Webster Engineering Corp.

D. H. Guild

225 Franklin Street

Boston, MA 02107

Tampa Electric Co.

H. I. Wilson

P.0. Box 111

Tampa, FL 33601

Tennessee Valley Authority

Energy Research

R. D. Boroughs

1345 Commerce Union Bank Building

Chattanooga, TN 37401

Tennessee Valey Authority

H. B. Flora, II I

1320 Commerce Union Bank Bldg.

Chattanooga, TN 37401

Texas Electric Service Co.

$W$. Keel

115 W. Seventh Street

Fort Worth, TX 76102
No. of

Copies

Tucson Gas \& Electric

A. A. Ward

220 W. 6th Street

Tucson, AZ 85701

Union Carbide Corp.

J. A. Bartz

Linde Division

61 East Park Drive

Tonawanda, NY 14150

Union Carbide Corp.

G. J. Kidd

ORGDP - K-25

P.0. Box P, Mail Stop 197

Oak Ridge, TN 37803

Union Carbide Corp.

$F$. Notaro

Linde Division

61 East Park Drive

Tonawanda, NY 14150

United Engineers \& Constructors

G. A. Englesson

30 S. 17th Street

Philadelphia, PA 19103

United Engineers \& Constructors

M. $\mathrm{Hu}$

30 S. 17th Street

Philadelphia, PA 19103

University of Bremen

K. Simhan

Bremen, WEST GERMANY

University of Iowa

J. F. Kennedy

Hydraulic Research Institute

Iowa City, IA 52240

University of Kentucky

T. E. Eaton

Mechanical Engineering

Department

Lexington, KY 40506 
No. of

Copies

U.S. Congress

G. Haimes

214 Massachusetts Avenue NE Washington, DC 20510

U.S. Fish and Wildlife Service

B. L. Foder

Information Transfer Specialist

National Power Plant Team

1451 Green Road

Ann Arbor, MI 48105

United States Steel Corp.

T. L. Myron

Research Laboratory

Monroeville, PA 15146

Utah Power \& Light

M. W. Russon

1407 W. N. Temple

Salt Lake City, UT 84103

Vermont Yankee Nuclear Power

E. Gaines, Jr.

77 Grove Street

Rutland, VT 05701

Virginia Electric \& Power Co.

S. Ragone

700 E. Franklin Street

Richmond, VA 23261

Washington Public Power Supply System

J. Chasse

P.0. Box 968

300 George Washington Way

Richland, WA 99352

Washington State University

R. W. Crain, Jr.

Department of Mechanical

Engineering

Pullman, WA 99164
No. of

Copies

Washington Water Power Co.

D. L. Olson

E. 1411 Mission Avenue

Spokane, WA 99202

Water Purification Associates

H. Gold

238 Main Street

Cambridge, MA 02142

Western States Water Council

J. A. Barnett

Executive Director

220 South 2nd East

Suite 200

Salt Lake City, UT 84111

Westinghouse Electric Corp.

G. E. Jablonka

Power Generation Systems

Engineering

700 Braddock Avenue, Room 9L51

East Pittsburgh, PA 15112

Westinghouse Electric Corp.

K. Kesavan

Advanced Reactor Division

P.0. Box 158

Madison, PA 15663

Westinghouse Electric Corp.

G. J. Silvestri

Steam Turbines Division - G108

Lester Branch

Box 9175

Philadelphia, PA 19113

Westinghouse Electric Corp.

K. A. Oleson

Steam Turbines Division - G108

Lester Branch

Box 9175

Philadelphia, PA 19113

L. E. Wilkinson

Consultant

6582 Ganon Street, S.E.

Salem, OR 97301 
No. of

Copies

William M. Rice University

W. G. Characklis

Environmental Science and Engineering

Houston, TX 77001

ONSITE

DOE Richland Operations Office

Energy Programs Division

H. E. Ransom

Westinghouse Hanford Company Hanford Engineering Development Laboratory

J. Fletcher

Pacific Northwest Laboratory

R. T. Allemann

J. A. Bamberger Daniel J. Braun David J. Braun

J. W. Currie

D. E. Deonigi

R. L. Dillon

D. W. Dragnich

R. L. Drake

F. P. Fabro

D. W. Faletti

J. W. Finnigan

T. J. Foley

B. C. Fryer

J. D. Goodenough

J. J. Hauth

A. J. Haverfield

C. H. Henager

A. B. Johnson

W. S. Kelly

R. S. Kemper

W. V. Loscutoff

R. P. Marshall

D. E. Olesen
No. of

Copies

Pacific Northwest Laboratory (contd)

Y. Onishi

H. L. Parry

L. T. Pederson

J. R. Sheff

G. C. Smith

J. S. Stoakes

A. M. Sutey

R. D. Tokarz

D. S. Trent

M. Vagins

R. A. Walter

R. L. Watts

R. D. Widrig

L. E. Wiles

C. E. Willingham

F. R. Zaloudek

File - B. M. Johnson (30)

Technical Information (5)

Publishing Coordination (2) 
